UNIVERSIDADE DE BRASÍLIA

FACULDADE DE AGRONOMIA E MEDICINA VETERINÁRIA PROGRAMA DE PÓS-GRADUAÇÃO EM AGRONOMIA

\title{
AVALIAÇÃO DE GENÓTIPOS DE GIRASSOL EM AMBIENTES NO CERRADO DO DISTRITO FEDERAL
}

\author{
ELLEN GRIPPI LIRA
}

DISSERTAÇÃO DE MESTRADO EM AGRONOMIA

BRASÍLIA/DF

FEVEREIRO/2016 


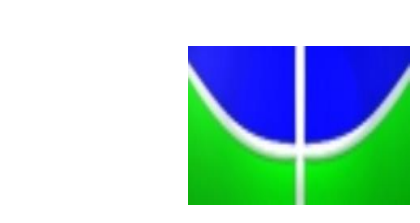

UNIVERSIDADE DE BRASÍLIA

FACULDADE DE AGRONOMIA E MEDICINA VETERINÁRIA PROGRAMA DE PÓS-GRADUAÇÃO EM AGRONOMIA

\section{AVALIAÇÃO DE GENÓTIPOS DE GIRASSOL EM AMBIENTES NO CERRADO DO DISTRITO FEDERAL}

ELLEN GRIPPI LIRA

ORIENTADOR: MARCELO FAGIOLI

COORIENTADOR: RENATO FERNANDO AMABILE

DISSERTAÇÃO DE MESTRADO EM AGRONOMIA

PUBLICAÇÃO: 101/2016

BRASÍLIA/DF

FEVEREIRO/2016 


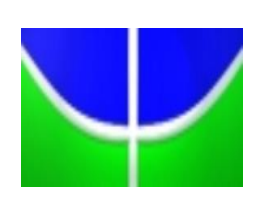

UNIVERSIDADE DE BRASÍLIA

FACULDADE DE AGRONOMIA E MEDICINA VETERINÁRIA

PROGRAMA DE PÓS-GRADUAÇÃO EM AGRONOMIA

\title{
AVALIAÇÃO DE GENÓTIPOS DE GIRASSOL EM AMBIENTES NO CERRADO DO DISTRITO FEDERAL
}

\author{
ELLEN GRIPPI LIRA
}

DISSERTAÇÃO DE MESTRADO SUBMETIDA AO PROGRAMA DE PÓSGRADUAÇÃO EM AGRONOMIA, COMO PARTE DOS REQUISITOS NECESSÁRIOS À OBTENÇÃO DO GRAU DE MESTRE EM AGRONOMIA.

APROVADA POR:

MARCELO FAGIOLI, Dr., Universidade de Brasília - UnB, CPF: 729.409.306-78, mfagioli@unb.br (Orientador)

ALEXEI DE CAMPOS DIANESE, Dr., Embrapa Cerrados, CPF: 561.235.821-00, alexei.dianese@embrapa.br (Examinador externo)

EDUARDO ALANO VIEIRA, Dr., Embrapa Cerrados, CPF: 999.533.669-34, eduardo.alano@embrapa.br (Examinador externo)

BRASÍLIA/DF, 29 de fevereiro de 2016. 


\section{FICHA CATALOGRÁFICA}

L768a Lira, Ellen Grippi.

Avaliação de genótipos de girassol em ambientes no cerrado do Distrito Federal /

Ellen Grippi Lira. - Brasília, DF, 2016.

$84 \mathrm{f}$.

Dissertação (Mestrado)- Universidade de Brasília, Faculdade de Agronomia e Medicina Veterinária, 2016.

Orientação de Marcelo Fagioli; co-orientação de Renato Fernando Amabile.

1. Helianthus annuus L. 2. Variabilidade. 3. Cerrado. Diversidade genética. 4.

Alternaria helianthi-praga de planta. 5. Resistência. 6. Qualidade-semente. I. Fagioli, Marcelo. II. Amabile, Renato Fernando. III. Título.

633.85098174 CDD 21

Catalogação na fonte: Shirley da Luz Soares Araujo (CRB1 1948)

\section{REFERÊNCIA BIBLIOGRÁFICA}

LIRA, E. G. Avaliação de genótipos de girassol em ambientes no cerrado do Distrito Federal. Brasília: Faculdade de Agronomia e Medicina Veterinária, Universidade de Brasília, 2016, 84 p. Dissertação de Mestrado.

\section{CESSÃO DE DIREITOS}

NOME DA AUTORA: Ellen Grippi Lira

TÍTULO DA DISSERTAÇÃO: Avaliação de genótipos de girassol em ambientes no cerrado do Distrito Federal.

GRAU: Mestre ANO: 2016

É concedida à Universidade de Brasília permissão para reproduzir cópias desta dissertação de mestrado para única e exclusivamente propósitos acadêmicos e científicos. A autora reserva para si os outros direitos autorais, de publicação. Nenhuma parte desta dissertação de mestrado pode ser reproduzida sem a autorização por escrito da autora. Citações são estimuladas, desde que citada a fonte.

\section{Ellen Grippi Lira}

CPF: 035.801.541-33

SQSW 504 Bloco I ap. 313, Sudoeste. Brasília/DF - Brasil CEP: 70.673-509

Tel: (61) 8112-7876 ～Email: ellen.grippi@gmail.com 


\section{AGRADECIMENTOS}

A Deus por ter me abençoado e capacitado ao longo desta caminhada, iluminando meus passos e cuidando de mim.

À minha família, em especial minha mãe, Sandra Grippi, pelo amor e por toda torcida, e minha avó Leny Grippi, pelo carinho incondicional.

Ao meu orientador Marcelo Fagioli e meu coorientador Renato Amabile, pelos ensinamentos e pela dedicação. Obrigada por esta oportunidade!

À Empresa Brasileira de Pesquisa Agropecuária - EMBRAPA, à Universidade de Brasília, através da Faculdade de Agronomia e Medicina Veterinária, muito obrigada! 


\section{SUMÁRIO}

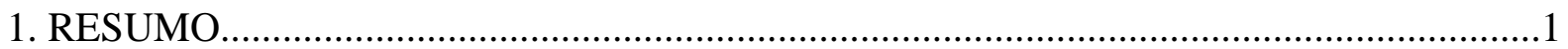

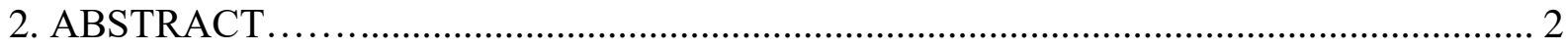

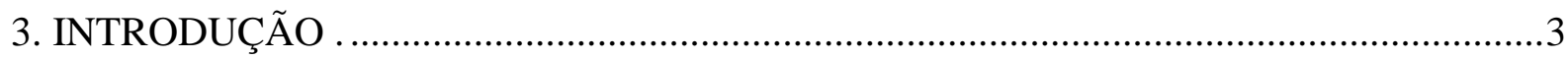

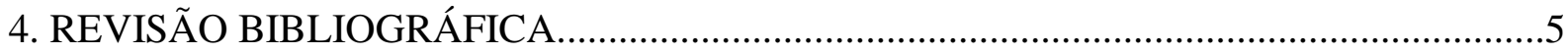

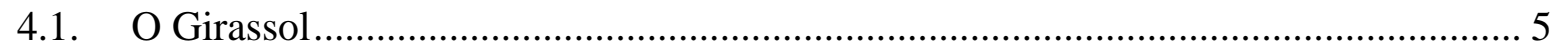

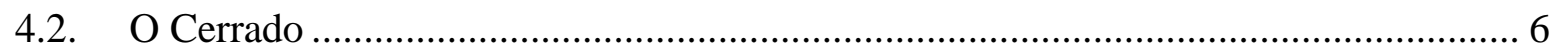

4.3. Potencialidades do girassol no Cerrado.......................................................... 7

4.4. Breve histórico do girassol no Brasil e no Cerrado ............................................... 8

4.5. Situações mundial e brasileira ................................................................. 8

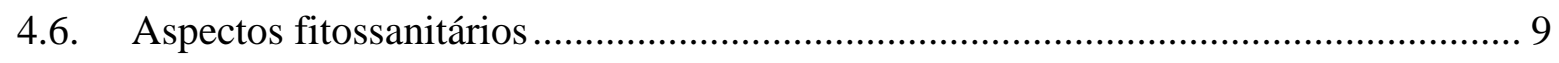

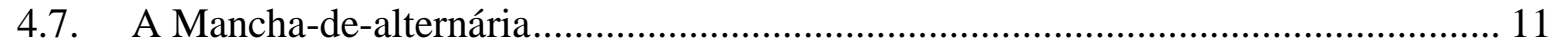

4.8. Qualidade fisiológica de sementes ......................................................... 12

4.9. Fatores que afetam a qualidade de sementes ............................................... 13

4.9.1. Condição inicial....................................................................................

4.9.2. Maturação fisiológica.............................................................................. 13

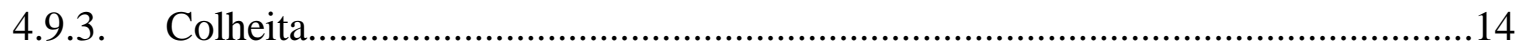

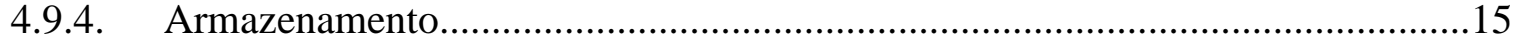

4.10. Testes para avaliação de sementes................................................................ 15

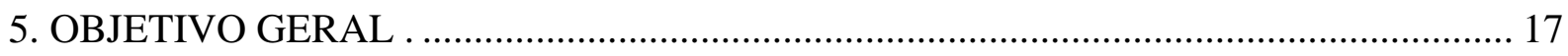

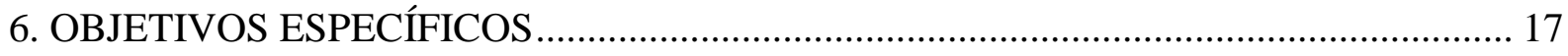

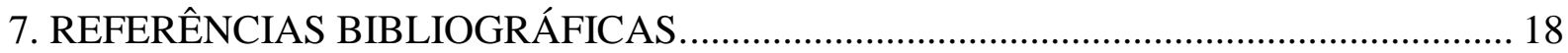

CAPÍTULO I - ESTIMATIVAS DE PARÂMETROS GENÉTICOS, CORRELAÇÕES FENOTÍPICAS, GENOTIIPICAS E AMBIENTAIS E VARIABILIDADE GENÉTICA EM GIRASSOL NO CERRADO...................................................................................25

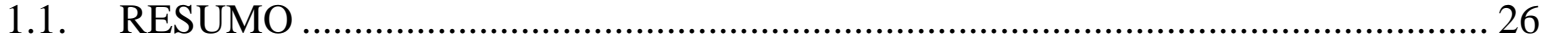

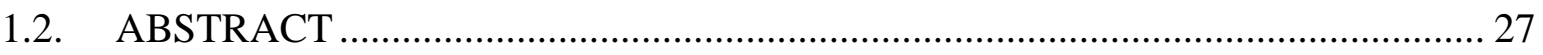

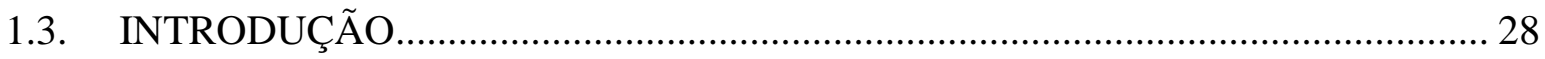

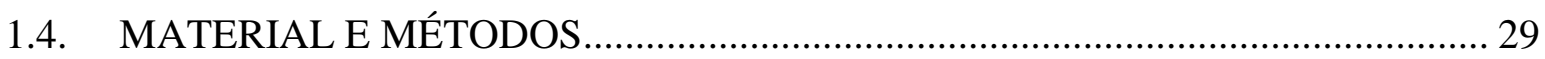

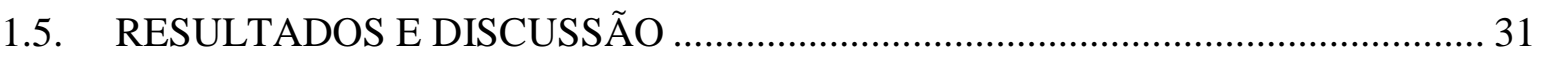

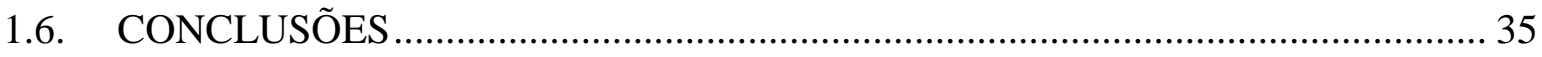




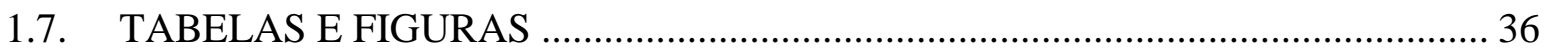

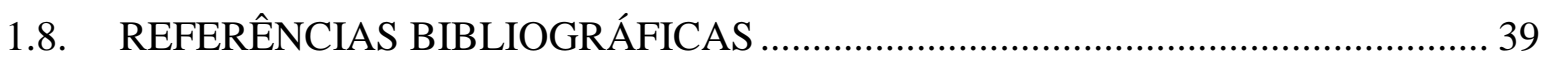

CAPÍTULO II - AVALIAÇÃO DE GENÓTIPOS DE GIRASSOL COM BASE EM CARACTERÍSTICAS MORFOAGRONÔMICAS EM AMBIENTES DO CERRADO BRASILEIRO. .42

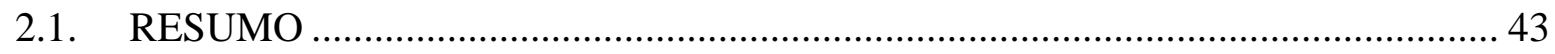

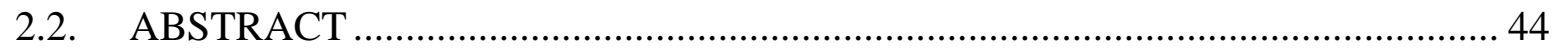

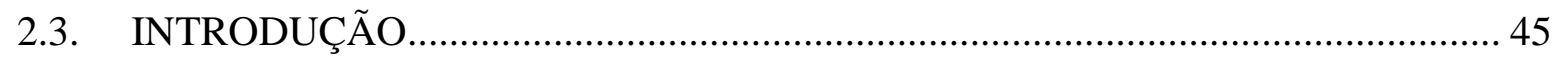

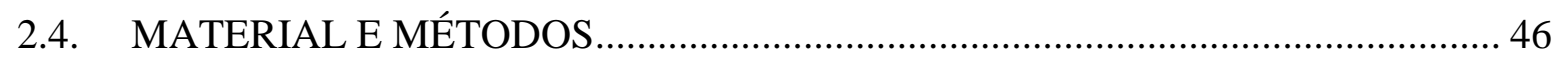

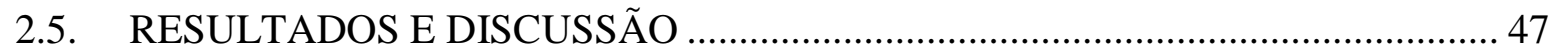

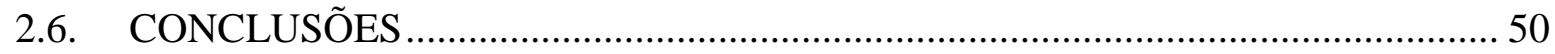

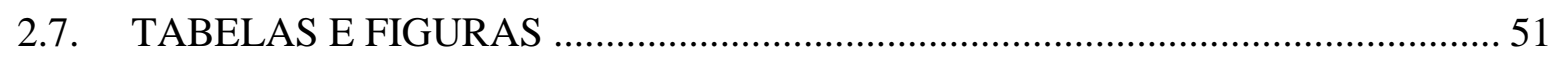

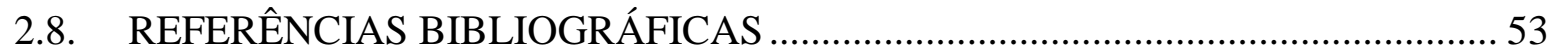

CAPÍTULO III - AVALIAÇÃO DA SEVERIDADE DA MANCHA-DE-ALTERNÁRIA EM GIRASSOL NO CERRADO DO DISTRITO FEDERAL...............................................5

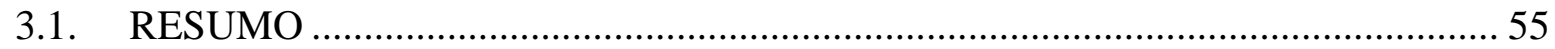

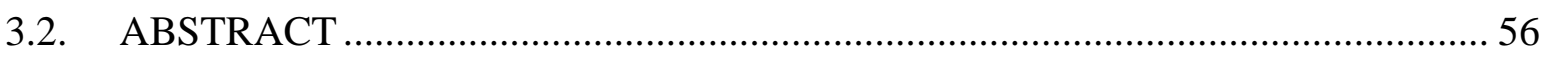

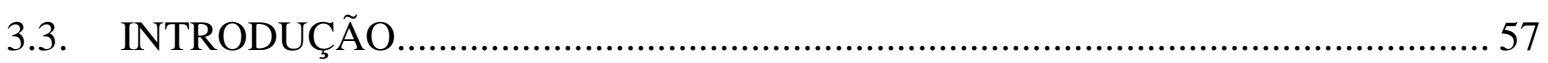

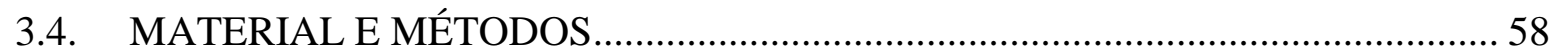

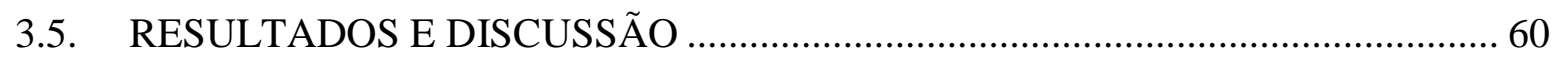

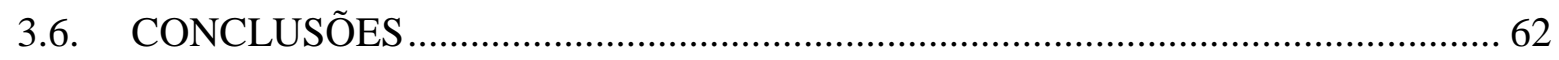

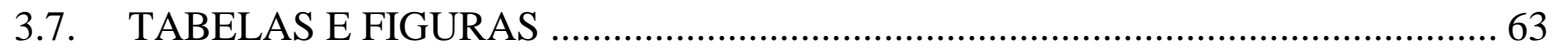

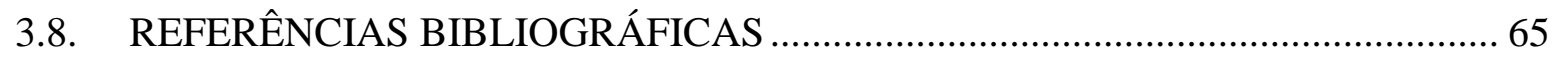

CAPÍTULO IV - AVALIAÇÃO DA QUALIDADE DE SEMENTES DE GIRASSOL NO

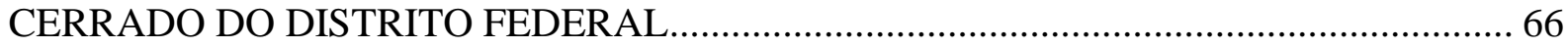

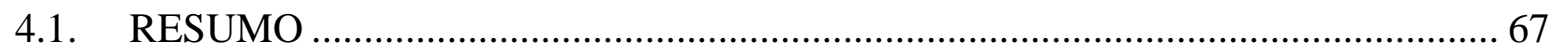

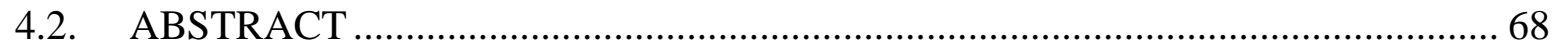

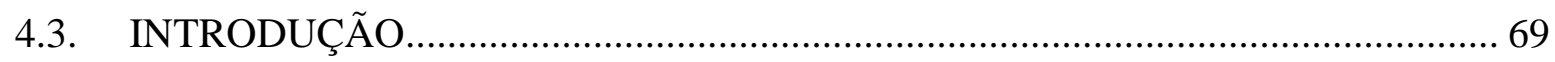

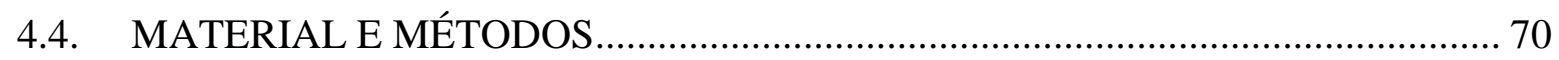

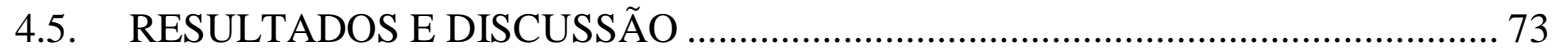

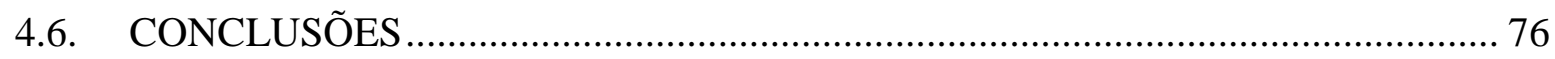

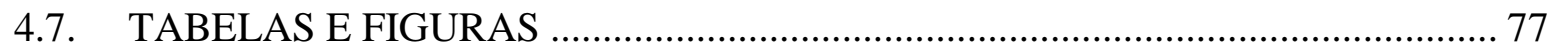




\section{RESUMO}

O girassol (Helianthus annuus L.) é uma importante espécie que oferece óleo de alta qualidade. Originário da América do Norte, hoje é cultivado em diversos países, fato que se deve à evolução dos programas de melhoramento. Esta cultura é também caracterizada pela sua adaptabilidade, apresentando-se como uma opção factível para o cultivo em safrinha. No Brasil, buscam-se materiais com alto teor de óleo, boa produtividade e resistência a condições abióticas e bióticas. O girassol é uma cultura de potencial para o Cerrado brasileiro, em virtude da viabilidade de seu uso em sistemas de rotação ou sucessão de cultivos em regiões produtoras de grãos. Nesse sentido, são necessários estudos e ações de pesquisa que forneçam informações quanto ao desempenho dos genótipos de girassol em diferentes locais e épocas de plantio, possibilitando o sucesso de programas de melhoramento. Neste trabalho, objetivou-se avaliar e caracterizar o comportamento de genótipos de girassol em ambientes no Cerrado do Distrito Federal, levando em consideração parâmetros genéticos, características morfoagronômicas, severidade da Mancha-de-alternária e qualidade de sementes. Foram avaliados 16 genótipos de girassol, no ano de 2014, em áreas experimentais da Embrapa - Centro de Pesquisa Agropecuária dos Cerrados, em Planaltina, DF, situada a $15^{\circ} 35^{\prime} 30^{\prime \prime}$ de latitude Sul, $47^{\circ} 42^{\prime} 30^{\prime \prime}$ de longitude Oeste e a altitude de $1.007 \mathrm{~m}$ e da Embrapa Produtos e Mercado, no Recanto das Emas, DF, a $15^{\circ}$ 54' $53^{\prime \prime}$ de latitude Sul, $48^{\circ} 02^{\prime} 14^{\prime \prime}$ de longitude Oeste e a altitude de $1.254 \mathrm{~m}$. O delineamento experimental utilizado foi de blocos ao acaso com quatro repetições. Análises de variância evidenciaram diferenças significativas entre os genótipos. O ambiente influenciou o desempenho dos genótipos e a severidade da Mancha-de-alternária. GNZ NEON, M734, SYN 3950HO, AGUARÁ 06, SYN 045, MG 360 e HELIO 251 obtiveram melhor desempenho no teste de condutividade elétrica. Houve maior presença de sintomas no terço inferior das plantas. Os genótipos CF 101, ADV 5504, BRS G42, HELIO 250, SYN 3950HO, BRS 323, HELIO 251, AGUARÁ 06 e AGUARÁ 04 expressaram menores valores de AACPD no terço inferior. Os valores de AACPD encontrados foram baixos. As condições ambientais não favoreceram a Mancha-de-alternária. HELIO 251, MG 305 e SYN 045 obtiveram os maiores rendimentos. BRS G42, CF 101 e BRS 323 apresentaram plantas mais baixas e ciclo mais precoce.

Palavras-chave: Helianthus annuus L., variabilidade, características morfoagronômicas, resistência, qualidade de sementes. 


\section{ABSTRACT}

Sunflower (Helianthus annuus L.) is an important crop because provides high-quality oil. Originally from North America, it is now grown in many countries, a fact that is due to the positive results of breeding programs. It is also characterized by its adaptability, being used as a second crop. In Brazil, materials with high oil content, high productivity and resistance to abiotic and biotic stress are the main goal. Sunflower has a great potential in the Brazilian Savannah, because it can be used in crop rotation. In this sense, it is necessary to have more studies and research activities that provide information about the performance of sunflower genotypes in different locations, enabling the success of breeding programs. This study aimed to characterize sunflower genotypes in different environments of the Brazilian Savannah in the Federal District, taking into account genetic parameters, agro-morphological characteristics, severity of alternaria leaf spot and seed quality. Sixteen sunflower genotypes were evaluated in 2014, at experimental

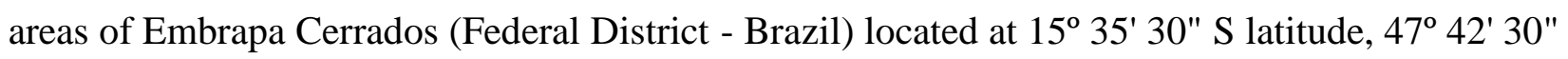
W longitude and $1.007 \mathrm{~m}$ above sea level, and of Embrapa Produtos e Mercado (Federal District - Brazil), located at $15^{\circ} 54^{\prime} 53^{\prime \prime}$ S latitude, $48^{\circ} 02^{\prime} 14^{\prime \prime} \mathrm{W}$ longitude and $1.254 \mathrm{~m}$ above sea level. A complete randomized block design was used. Analysis of variance showed significant differences among genotypes. The environment influenced the performance of the genotypes and the severity of alternaria. GNZ NEON, M734, SYN 3950HO, AGUARÁ 06, SYN 045, MG 360 and HELIO 251 detained best results at electrical conductivity test. There were more symptoms of alternaria leaf spot in the lower third of the plants. The genotypes CF 101, ADV 5504, BRS G42, HELIO 250, SYN 3950HO, BRS 323, HELIO 251, AGUARÁ 06 and AGUARÁ 04 expressed lower AUDPC values in the lower third. The AUDPC values were low, indicating little disease. Environmental conditions did not favor alternaria leaf spot. The genotypes HELIO 251, MG 305 and SYN 045 had the best results for grain yield. BRS G42, CF 101 and BRS 323 detained lower values for height and days to flowering.

Key words: Helianthus annuus L., variability, agro-morphological characteristics, resistance, seed quality. 


\section{INTRODUÇÃ̃o}

O Brasil, quinto maior país do mundo em área territorial, abrange diferentes ecossistemas. Dentre estes, o Cerrado se destaca como segundo maior bioma em extensão e distribui-se pelas regiões Centro-Oeste, Sudeste, Norte e Nordeste, com uma área de $2.036 .448 \mathrm{~km}^{2}$, correspondente a 23,92\% do território nacional (EITEN, 1993; RIBEIRO; WALTER, 1998; IBGE, 2004). Além de possuir vasta biodiversidade, o Cerrado é um ambiente de grande potencial agrícola, que vem sendo explorado através de pesquisas que visam introduzir novas espécies e/ou variedades.

A agricultura tem como objetivo principal a produção de alimentos a fim de suprir a necessidade do homem em relação à quantidade e qualidade dos mesmos. O estudo das diferentes espécies e características como adaptabilidade permite o cultivo de plantas em ambientes diferentes daqueles dos centros de origem, como é o caso da soja e do trigo, introduzidos com sucesso no Cerrado. A pesquisa permite a diversificação de cultivos e, para tanto, a busca por genótipos adaptados deve ser constante.

Os sistemas agrícolas buscam aumentar a produção por área cultivada, porém a preocupação com a sustentabilidade deve perpassar toda a cadeia produtiva. $\mathrm{O}$ uso consciente dos recursos naturais corresponde àquele que supre as necessidades atuais e, ao mesmo tempo, gera condições para a conservação da capacidade produtiva. A pesquisa tem papel fundamental na busca do equilíbrio entre agronegócio, sociedade e uso racional dos recursos naturais (FALEIRO et al., 2008). Uma técnica agrícola que visa este equilíbrio é a rotação de culturas, que se caracteriza pela alternância de espécies. Sistemas de monocultura ou sucessão contínua como soja-milho podem comprometer o uso dos recursos naturais em longo prazo. Por isso, outras espécies devem ser estudadas e introduzidas a fim de contribuir com a conservação dos ecossistemas e com a diversificação de produção. O girassol (Helianthus annuus L.) é uma opção para a rotação de culturas e pode ser incluído no sistema de sucessão após espécies de verão, como é o caso da soja e do milho (PELEGRINI, 1985; CASTRO et al., 1997).

Nesse contexto, o presente trabalho tem por objetivo o estudo de diferentes genótipos de girassol em três ambientes de produção no Cerrado do Distrito Federal, a fim de buscar genótipos mais adaptados e com maior potencial produtivo no bioma em questão, sendo observados 
parâmetros genéticos, características morfoagronômicas, severidade da Mancha-de-alternária e qualidade de sementes. 


\section{REVISÃO BIBLIOGRÁFICA}

\subsection{O Girassol}

O girassol (Helianthus annuus L.), pertencente à família Asteraceae, é uma dicotiledônea anual, cujo gênero possui em torno de 49 espécies, sendo 12 espécies anuais e 37 perenes (UNGARO, 1990). Dentre as espécies, H. annuus L. recebe destaque pelo seu uso para produção de óleo de alta qualidade nutricional. Além disso, o girassol possui alto teor de óleo no grão, com valores que variam de 38 a 50\% (LEITE et al., 2005).

A espécie pode ser explorada para diferentes fins. A semente pode ser utilizada para consumo in natura ou para extração de óleo pela indústria, processo através do qual é produzido um resíduo usado na alimentação animal - a torta. O farelo, usado como ração, pode ser destinado para alimentação de bovinos, suínos e aves. A cultura pode também ser utilizada para a produção de silagem para nutrição animal (ROSSI, 1998). Na floricultura, o girassol ornamental ganha destaque pela beleza de sua inflorescência. A raiz pivotante participa de uma efetiva reciclagem de nutrientes e após sua morte, a espécie contribui para a manutenção da matéria orgânica.

A cultura do girassol é originária da América do Norte e hoje, através de avanços em pesquisas e programas de melhoramento, é cultivada com sucesso também em outros continentes. No Brasil, o melhoramento genético busca materiais precoces (OLIVEIRA et al., 2005), de porte baixo, com alta produtividade e resistentes a condições abióticas e bióticas, visando o uso da cultura durante a entressafra. Aliadas à seleção de genótipos mais adaptados, várias práticas contribuem para o aumento do rendimento da cultura como a adequação dos genótipos à época de semeadura (AMABILE et al., 2007). A produtividade do girassol pode ser influenciada por vários fatores, como número de aquênios por capitulo, teor de óleo e diâmetro do capítulo. A interação de características agronômicas entre si e com o ambiente permite a manifestação do potencial genético do material utilizado (SCHIMIDT; SILVA, 1986).

O girassol é uma planta alógama, ou seja, se reproduz preferencialmente por cruzamento entre indivíduos. Apesar de possuir flor completa, o girassol não realiza autofecundação, tal fato se deve à dicogamia dos órgãos sexuais e à autoincompatibilidade dos mesmos. A dicogamia da espécie é do tipo protandria, em que o pólen fica maduro antes que o estigma fique receptivo. Portanto, a polinização cruzada e a presença de insetos polinizadores são imprescindíveis para a 
produção de grãos (FREE, 1993). O principal agente polinizador é a abelha. Há inclusive possibilidade de integrar a produção de girassol com a produção de mel, contribuindo para aumento de receita e diversificação de oferta de produtos por parte do produtor.

A produção de híbridos de girassol passou a ser viável após a possibilidade de explorar a macho-esterilidade na espécie, que foi identificada por Leclercq na França. Após a identificação de fontes de macho-esterilidade, foi possível a utilização prática da heterose em girassol (SKORIC, 1992). A primeira fonte de citoplasma macho estéril (CMS) foi obtida através do cruzamento entre Helianthus petiolaris Nutt com H. annuus L. Em seguida, o pesquisador Kinman, desenvolveu linhagens com o gene restaurador de fertilidade, possibilitando a obtenção de híbridos em 1972. A macho-esterilidade pode ser induzida através de fito-hormônios como ethrel e ácido giberélico. A hibridação interespecífica com espécies selvagens pode contribuir para o aumento da variabilidade da espécie, visando obtenção de materiais resistentes a doenças e pragas, com maior teor e melhor qualidade de óleo e tolerância à seca.

\subsection{O Cerrado}

O Cerrado, detentor de vasta biodiversidade, ocupa a posição de segundo maior bioma brasileiro, com área de 2.036.448 km², correspondente a 23,92\% do território nacional (EITEN, 1993), ficando atrás apenas da Amazônia. Está distribuído pelo Brasil e contempla os Estados de Mato Grosso do Sul, Bahia, Mato Grosso, Goiás, Tocantins, Maranhão, Roraima, Rondônia, São

Paulo, Amapá, Pará, Ceará, Piauí, Minas Gerais e Distrito Federal. (EMBRAPA, 2011). É um bioma maioritariamente brasileiro, salvo pequenas porções localizadas em território boliviano e paraguaio (PROENÇA et al., 2002).

De forma geral, o clima do Cerrado é marcado por um contraste: verões chuvosos e invernos secos. O período de chuva frequentemente ocorre de outubro a abril, enquanto a época de seca acomete os meses de maio a setembro (ADÁMOLI et al., 1987). No início da seca pode ocorrer a presença de nevoeiros durante a manhã, favorecendo a formação de orvalho sobre as plantas e umedecendo o solo. Em contrapartida, a umidade relativa do ar pode chegar a apenas 15\% no período da tarde (SETTE, 2004). Na maior parte do tempo, as temperaturas médias do ar 
variam de $22^{\circ} \mathrm{C}$ a $27^{\circ} \mathrm{C}$. Predominam os solos Latossolos, porém ocorrem também Neossolos e Cambissolos (MACEDO, 1996; RESENDE et al., 2002).

Para atenuar os períodos de grande seca, a irrigação via pivô-central vem sendo utilizada e está cada vez mais difundida, caracterizando uma alternativa importante para o sistema de produção no Cerrado. Estima-se que a área irrigada atinja mais que 470 mil hectares (LIMA et al., 2009).

O Cerrado contribui para o sucesso da agricultura nacional, e há anos recebe destaque devido a seu potencial. A ocupação do Cerrado pode incrementar a produção anual de grãos. Para tanto, depende-se de diversas condições, contemplando questões políticas e econômicas nacionais, bem como tecnologias que possam contribuir para ganhos expressivos em eficiência dos sistemas de produção (AMABILE; BARCELLOS, 2009).

\subsection{Potencialidades do girassol no Cerrado}

O girassol é uma alternativa rentável em sistemas de rotação ou sucessão de cultivos em regiões produtoras de grãos (VIEIRA, 2000). Nesse sentido, o Cerrado se apresenta como uma região de grande potencial de expansão da cultura. Seu cultivo pode ser realizado na entressafra e é viabilizado pelo aproveitamento do sistema de produção e pela menor sensibilidade da espécie em condições de safrinha. Além do mais, com a produção de girassol, é possível contribuir para a otimização da utilização da terra, máquinas e mão-de-obra (SILVA et al., 2007). A cultura é tolerante ao estresse hídrico, fato que contribui para a expansão da mesma.

A espécie pode ser cultivada por pequenos, médios e grandes produtores. Ela vem sendo utilizada em sistemas soja ou soja-milho como alternativa para diversificar produção. Pequenas propriedades podem destinar a produção para fabricação integrada de mel ou para alimentação de aves e/ou humanos. De modo geral, a cultura do girassol é caracterizada por apresentar maior resistência ao frio, seca e calor quando comparada a outras espécies, como o milho e o sorgo.

O rendimento pode variar de acordo com a cultivar utilizada e com as condições ambientais (ABREU et al., 2001). Nesse sentido, o estudo de genótipos se faz necessário, uma 
vez que ainda faltam informações sobre tipos adaptados e épocas de semeaduras adequadas para diferentes ambientes (COSTA et al., 2000).

\subsection{Breve histórico do girassol no Brasil e no Cerrado}

Os primeiros cultivos de girassol no Brasil datam do século XIX na região Sul, no entanto, a cultura não estava adaptada às condições ambientais. Inicialmente, a espécie enfrentava forte competição com outros cultivos, como milho e algodão, e a falta de pesquisa impossibilitava sua produção.

O Instituto Agronômico de Campinas (IAC) iniciou os estudos com girassol no ano de 1937, porém foi a partir da década de 70 que houve crescente interesse pela produção, principalmente pela viabilidade do óleo vegetal.

Ainda hoje existem entraves para o crescimento da produção. A logística é um fator limitante. O elevado custo do transporte quando comparado com a soja deixa a cultura em desvantagem.

O Mato Grosso se destaca como um importante estado produtor, correspondendo a mais ou menos 76,8\% da produção nacional (CONAB, 2015). A posição de destaque pode estar relacionada com a existência de um sistema industrial para fabricação do óleo de girassol.

\subsection{Situações mundial e brasileira}

O girassol é produzido em todos os continentes e destacam-se como grandes produtores de grãos a Rússia, a Ucrânia, a União Europeia e a Argentina (LAZARATO et al., 2005). A cultura ocupa a terceira posição no ranking das oleaginosas, em produção mundial de óleo, ficando atrás da soja e da colza. Mundialmente, estima-se uma média de mais de 25 milhões de hectares colhidos em 2013 (FAOSTAT, 2014).

A produção brasileira do óleo de girassol não é suficiente para suprir a demanda interna pelo produto, razão pela qual parte do mesmo é importada de países como a Argentina. Tal fato 
comprova o potencial de exploração e expansão da cultura. No entanto, a oferta do produto é instável no mercado. Para estabelecer de forma constante a cultura do girassol, são necessárias medidas relacionadas ao sistema de logística e escoamento de produção nacional, ao incentivo e à pesquisa de tecnologias específicas de produção da cultura.

O consumo do óleo de girassol ainda é baixo quando comparado ao consumo do óleo de soja. Segundo dados do Instituto Brasileiro de Geografia e Estatística (IBGE), o consumo per capita de óleo de girassol no Brasil é de 200 mililitros ao ano, enquanto a soja apresenta um valor de 6,85 litros. Em relação a tal diferença, o preço é um fator determinante. O óleo de girassol, em mesma quantidade, vale, no mínimo, o dobro do de soja.

Apesar do exposto, o girassol se destaca como uma cultura importante, pois fornece óleo de alta qualidade e em quantidades superiores às outras culturas oleaginosas. Pela grande adaptabilidade, pode ser cultivado em diferentes ambientes, garantindo assim uma produção rentável para o produtor que deseja aumentar sua receita, otimizar sua área e/ou diversificar sua produção.

Como exemplo das vantagens produtivas do girassol, pode-se citar a pesquisa desenvolvida pela Embrapa - Empresa Brasileira de Pesquisa Agropecuária, que possui ensaios em locais secos, onde o girassol produz acima da média nacional, que é aproximadamente 1,5 mil quilos por hectare.

\subsection{Aspectos fitossanitários}

Como todas as espécies cultivadas, o desenvolvimento e expansão da produção de girassol podem ser prejudicados pelo ataque de patógenos. Segundo Zimmer e Hoes (1978), o fator que mais afeta a produtividade do girassol é a ocorrência de doenças. Os danos causados à cultura do girassol podem alcançar $100 \%$ sob condições climáticas favoráveis às doenças (LEITE, 2005).

Dentre as doenças, destacam-se a Mancha-de-alternária, a podridão branca, o míldio, a ferrugem e o oídio. A Mancha-de-alternária é causada pelo fungo Alternaria helianthi (Hansf.) 
Tubaki e Nishihara, que afeta folhas, hastes e capítulo (CASTRO, 1996). Inicialmente, pontos necróticos com halo amarelecido causam redução da área fotossintética. Em casos mais graves, pode haver senescência das folhas e/ou morte da planta. Segundo Maldaner (2009), a desfolha precoce pode ocorrer em decorrência do aumento da área foliar necrosada.

A podridão branca, causada por Sclerotinia sclerotiorum, é favorecida por condições de temperaturas amenas e alta umidade. Os escleródios podem permanecer muitos anos no solo, portanto, deve-se atentar para o histórico da área. O míldio, causado pelo fungo Plasmopara halstedii, caracteriza-se pela presença de estruturas branco-acinzentadas na parte inferior das folhas e é favorecido por alta umidade e temperaturas amenas. A ferrugem, causada pelo fungo Puccinia helianthi, pode ser identificada através de pústulas pulverulentas de cor alaranjada e é favorecida por alta umidade e temperaturas amenas. Já o oídio, causado pelo fungo Erysiphe cichoracearum, se desenvolve em ambientes mais secos e de maior temperatura. Seu sintoma característico é a presença de estruturas aveludadas brancas ou cinzas sobre as folhas.

A maioria das doenças que afetam a cultura do girassol é causada por fungos (MENTEN, 1985). Existem outras doenças, menos frequentes ou que causam menos danos, como é o caso da mancha bacteriana e do crestamento bacteriano, que podem se disseminar rapidamente através da água da chuva. A transmissão também ocorre pela semente (ZIMMER; HOES, 1978). Estas são doenças favorecidas por alta umidade e altas temperaturas.

O conhecimento do local, bem como seu histórico, e a adequação do plantio em épocas menos favoráveis a certos patógenos pode contribuir para um manejo fitossanitário eficiente do sistema de produção de girassol. Existem fungicidas no mercado registrados para a cultura do girassol, que podem atuar de forma preventiva e/ou curativa, contribuindo para obtenção de lavouras mais limpas. O uso de genótipos menos suscetíveis é também uma importante forma de garantir uma boa produção.

Nesse sentido, os estudos devem considerar a resistência dos materiais ao ataque dos patógenos. A Mancha-de-alternária é o principal problema fitossanitário do girassol (MORAES et al., 1983), e por isso, a avaliação da resistência se faz necessária quando o objetivo é analisar genótipos, visando o uso de materiais mais adaptados. 


\subsection{A Mancha-de-alternária}

Causada pelo fungo Alternaria helianthi (Hansf.) Tubaki e Nishihara, a Mancha-dealternária pode afetar toda a cultura do girassol e tem sido relatada em todas as áreas cultivadas do mundo. Descrita pela primeira vez por Hansford na Uganda em 1943, a doença, segundo Carson (1982) pode causar perdas de produtividade e redução do teor de óleo.

Os sintomas típicos são pontos necróticos com halo amarelecido, que podem prejudicar o desenvolvimento da planta pela potencial redução da área fotossintética. Em ataques mais extremos, o fungo pode causar um processo de senescência das folhas e/ou de morte da planta. Os primeiros sintomas podem ser visualizados nas folhas baixeiras, e conforme a doença avança, são frequentes lesões nos pecíolos, hastes e capítulos (AQUINO et al., 1971; TANAKA, 1981; MORAES et al., 1983). Quando ocorre alta intensidade de ataque, é possível a ocorrência de necrose dos tecidos, provocando crestamento, desfolha e morte das plantas (LEITE, 1997).

Há relatos da doença em diferentes épocas e regiões de cultivo, sendo temperaturas entre 25 a $30^{\circ} \mathrm{C}$ e alta umidade relativa fatores que contribuem para a germinação de conídios (DAVET et al. 1991) e, consequentemente, para o aumento da severidade de ataque. A ocorrência de precipitação, gerando presença de água livre, pode favorecer a entrada dos esporos do fungo pelos estômatos e pode ajudar na dispersão dos mesmos. A fase de enchimento dos grãos pode ser crítica caso haja mistura dos conídios do patógeno com pólen do capítulo, contribuindo para o aumento da germinação e ramificação dos tubos germinativos (ALLEN et al., 1983).

A resistência genética é desejável, uma vez que corresponde ao meio mais econômico de se reduzir os danos causados pela doença (DAVET et al., 1991). O controle é difícil após a instalação da doença na lavoura, razão pelas quais estratégias de manejo como a resistência são cada vez mais requeridas. 


\subsection{Qualidade fisiológica de sementes}

A qualidade das sementes é fundamental para o estabelecimento das culturas, permitindo que estas expressem seu potencial. Para determinação desta qualidade em girassol, usam-se testes como o de germinação (BRASIL, 2009).

Dentre as características avaliadas em relação às sementes, o vigor é determinante para obter uma emergência rápida e uniforme, além de contribuir para o crescimento de plântulas normais (AOSA, 1983).

De forma geral, a qualidade de sementes é resultado de um conjunto de aspectos que interagem entre si. Fatores genéticos, físicos, fisiológicos e sanitários influenciam as sementes das plantas. As condições ambientais também são importantes, como por exemplo, a disponibilidade de água na semeadura (BACKES et al., 2008), uma vez que a falta hídrica pode comprometer o desenvolvimento da planta. Castro e Farias (2005) apontam a temperatura do ar entre 20 e $25^{\circ} \mathrm{C}$ como uma das premissas para boa emergência da cultura do girassol.

Em conformidade com dados apresentados pela CONAB (2011) a média de produtividade de girassol no Brasil é de $1454 \mathrm{~kg} \mathrm{ha}^{-1}$, valor pequeno quando comparado às médias de outros países, evidenciando a possibilidade de melhorias nacionais. A falta de qualidade das sementes é uma das razões que pode contribuir para baixas médias de rendimento.

Para garantir o sucesso da expansão da cultura do girassol no Cerrado faz-se necessária a oferta de materiais com sementes de alta qualidade. Germinação e vigor são fundamentais para alcançar altas produtividades e por isso mais pesquisas devem ser realizadas a fim de auxiliar programas de melhoramento. 


\subsection{Fatores que afetam a qualidade de sementes}

\subsubsection{Condição inicial}

O sucesso de uma produção começa no preparo inicial para o plantio. O uso de sementes sadias, com maior potencial genético e mais adaptadas ao local de produção são fatores que contribuem para o alcance de altas produtividades.

Em relação às características genéticas, tem-se como destaque o ciclo do material, a altura, a produtividade e a resistência a fatores bióticos e abióticos. Com isso, ressalta-se a importância da escolha de uma variedade adequada. Deve-se levar em conta também a pureza do lote de sementes, avaliando se há presença de material inerte ou sementes de outras espécies. Cor, tamanho, forma, peso, danos mecânicos e grau de umidade também influenciam o estabelecimento inicial das plantas.

A sanidade das sementes pode ser decisiva na instalação da lavoura. Deve-se tentar minimizar possíveis perdas de qualidade de sementes (BALLA et al., 1997). A presença de microrganismos e/ou pragas pode comprometer o desenvolvimento da planta. A propagação destes contaminantes pode ser ocasionada tanto nas fases de colheita e armazenamento quanto no próprio campo. O conhecimento a respeito da origem do material e seu histórico é medida importante para evitar contaminações e introdução de patógenos.

Quanto à fisiologia das espécies, leva-se em conta o potencial germinativo, a longevidade e o vigor esperado por parte da semente. De forma geral, uma lavoura sadia e vigorosa, associada à adubação adequada, permite o armazenamento por mais tempo e com menor supressão de qualidade.

\subsubsection{Maturação fisiológica}

A maturação fisiológica no girassol corresponde ao momento em que há maior concentração de óleo e massa seca nos aquênios (ANDERSON, 1975). Caso ocorra deficiência 
hídrica neste período, pode haver a formação de grãos mais leves e mais propensos a processos de deterioração. Em contrapartida, o excesso de água pode agilizar o decurso da deterioração.

Nesse contexto, o ciclo do material utilizado é de extrema importância, pois se deve evitar que a maturação ocorra em momentos de seca. No cerrado, caso o plantio seja muito tardio ou a cultivar apresente um ciclo muito longo, as chances são maiores de se deparar com uma condição menos favorável.

\subsubsection{Colheita}

A colheita consiste em uma prática de extrema importância para manutenção da qualidade das sementes e recomenda-se que seja realizada o mais próximo da maturidade fisiológica. Esta prática é influenciada por diversos fatores, como condições climáticas, teor de água e tipo de colheita (BALLA et al., 1997). Sementes colhidas no momento inadequado expressam menor potencial de armazenagem.

Durante a colheita podem ocorrer danos nas sementes, causando rachaduras que podem reduzir vigor e favorecer a entrada de patógenos, com consequente perda de qualidade das sementes. Quanto ao girassol, recomenda-se colher quando houver umidade dos aquênios de aproximadamente $15 \%$, uma vez que alta umidade configura um entrave à colheita mecânica (DIOS, 1994).

O girassol é uma cultura de maturação predominantemente desuniforme, o que pode ser explicado pela própria configuração da planta, caracterizada pela abertura das flores do capítulo no sentido das bordas para o centro (ZIMMERMAN; ZIMMER, 1978). Este fato demonstra a dificuldade em definir o momento ideal da colheita, pois diferente de outras espécies, é difícil

precisar o instante exato para colher o girassol. Alguns trabalhos fornecem informações para auxiliar a identificação do momento mais favorável, garantindo maior assertividade por parte dos produtores. Silveira (2000) aponta o início da queda de folhas liguladas e a troca de cor do dorso do capítulo de verde para amarelo como indicadores de maturidade fisiológica. 


\subsubsection{Armazenamento}

A manutenção da qualidade fisiológica das sementes durante o armazenamento é influenciada por fatores ambientais do armazém e pela qualidade das sementes. Muitas perdas podem ocorrer caso as condições de armazenagem não estejam de acordo com a necessidade de cada tipo de semente. De acordo com Villa e Roa (1979), o teor de água, a temperatura e a duração da armazenagem são exemplos de fatores que interferem no processo de deterioração.

Quanto à parte biótica, destacam-se os fungos dos gêneros Penicillium e Aspergillus, que acometem sementes armazenadas e podem ocasionar diminuição da taxa de germinação.

Segundo Halder e Gupta (1980), aumento de lixiviação de eletrólitos tende a ocorrer quando as sementes de girassol permanecem armazenadas por períodos maiores que três meses em ambientes de alta umidade, contribuindo para o processo de deterioração.

Em condições de armazenamento convencional, ressalta-se a importância de técnicas de resfriamento artificial, que contribuem para manutenção de condições ideais, possibilitando maior duração da armazenagem das sementes. De acordo com Baudet (2003) e Delouche (2002), em condições controladas de umidade e temperatura, é possível conservar as sementes por maiores períodos.

Baixa produtividade pode acontecer caso a colheita e a armazenagem não sejam adequadas (CHANNAKESHAVA et al., 2000), mesmo que se considere um material de alta qualidade genética.

\subsection{Testes para avaliação de sementes}

Considerando a importância da qualidade das sementes e os vários fatores que a afetam, é crescente a demanda por testes que avaliem a qualidade dos materiais. Um fator importante é a germinação, que pode ser avaliada a fim de caracterizar o potencial de determinadas sementes. Entretanto, este teste por si só não permite concluir pela qualidade ou não de um lote, uma vez que não identifica diferenças em fases iniciais de deterioração e, de forma geral, não demonstra variações a respeito do desempenho entre lotes (CARVALHO; NAKAGAWA, 2000). 
Testes de vigor são importantes, pois auxiliam na seleção dos melhores materiais e propiciam conhecimentos de valor para o plantio. Dentre os testes, destacam-se os associados a processos fisiológicos de deterioração, como atividades respiratórias e enzimáticas e integridade das membranas celulares (POLLOCK; ROOS, 1972; ABDUL-BAKI; ANDERSON, 1973). Exemplos são os testes de condutividade elétrica e de lixiviação de potássio.

A condutividade elétrica pode ser estimada com baixo custo e por diferentes laboratórios, com grande utilidade para programas de controle de qualidade de sementes. Os resultados são obtidos rapidamente e é possível estimar o potencial de armazenamento e, em alguns casos, o potencial de emergência das plântulas em campo (FRIGERI, 2007). Este teste, classificado como um teste bioquímico (BEWLEY; BLACK, 1994; MARCOS FILHO, 2005), abrange dois princípios, o físico, pela avaliação da passagem de corrente elétrica por meio da solução de embebição, e o biológico, pela perda de lixiviados das membranas celulares para o ambiente, relacionados à deterioração das sementes. Altas quantidades de lixiviados geram altos valores de condutividade elétrica, indicando alta perda de eletrólitos e consequentemente menor vigor. Isso ocorre devido à relação existente entre a libração de eletrólitos e a desorganização das membranas das células. Por outro lado, valores baixos de condutividade elétrica indicam menor desorganização do sistema de membranas, sugerindo maior potencial fisiológico (VIEIRA et al., 2002).

A lixiviação de potássio é outra opção de teste rápido do vigor das sementes, que também permite aferições quanto à integridade das membranas. De acordo com Marcos Filho et al. (1982), a lixiviação de íons de potássio caracteriza grande parte da condutividade elétrica. 


\section{OBJETIVO GERAL}

Avaliar o comportamento de genótipos de girassol em ambientes no Cerrado do Distrito Federal.

\section{OBJETIVOS ESPECÍFICOS}

Estimar parâmetros genéticos, correlações genotípicas, fenotípicas e ambientais e variabilidade de genótipos de girassol;

Avaliar os genótipos com base nas características morfoagronômicas em ambientes do Cerrado;

Avaliar a severidade da Mancha-de-alternária em girassol cultivado em ambientes do Cerrado;

Avaliar a qualidade fisiológica (germinação e vigor) das sementes provenientes dos genótipos cultivados em ambientes do Cerrado. 


\section{REFERÊNCIAS BIBLIOGRÁFICAS}

ABDUL-BAKI, A.A.; ANDERSON, J.D. Vigor determination in soybean seed by multiple criteria. Crop Science, Madison. v.13, n.6, p.630-633. 1973.

ABREU, J.B.R.; MENEZES, J.B.O.X.; SCOFIELD, H.L.; SCOLFORO, L.; ARAÚJO, L.A.; SOUZA, M.M; JUNIOR, E.P.N.; SANTOS, A.P. Avaliação da produção de capítulos e de matéria seca total de quatro cultivares de girassol (Helianthus annuиs). In: $14^{\mathrm{a}}$ Reunião Nacional de Pesquisa de Girassol. Simpósio Nacional Sobre a Cultura do Girassol, 1., 2001, Rio Verde. Resumos, p. 48- 49.

ADÁMOLI, J.; MACEDO, J.; AZEVEDO, L.G.; NETTO, J.M. Caracterização da região dos Cerrados. In: GOEDERT, W. J. (EdS.). Solos dos Cerrados: tecnologias e estratégias de manejo. Planaltina, DF: EMBRAPA - CPAC; São Paulo: NOBEL, 1987. p. 33-98.

ALLEN, S.J., BROWN, J.F. \& KICHMAN, J.K. The infection process, sporulation and survival of Alternaria helianthi on sunflower. Annals of Applied Biology. p.102:413-419. 1983.

AMABILE, R.F.; BARCELlOS, A. de O. Produção Agropecuária e Florestal: demandas para a pesquisa. In: FALEIRO, F. G.; NETO, A. L. F. (Eds.). Savanas: demandas para pesquisa. Planaltina, DF: Embrapa Cerrados, 2009. p.53-67.

AMABILE, R.F.; MONTEIRO, V.A.; AQUINO, F.D. V. de; CARVALHO, C.G.P. de; RIBEIRO JÚNIOR, W.Q.; FERNANDES, F.D.; SANTORO, V.L. Avaliação de genótipos de girassol em safrinha no Cerrado do Distrito Federal. In REUNIÃO NACIONAL DE PESQUISA DE GIRASSOL, 17. 2007. Uberaba. Anais. Londrina: Embrapa Soja, 2007. p.109-112.

ANDERSON, W. K. Maturation of sunflower. Australian Journal of Experimental Agriculture and Animal Husbandry, v. 15, p. 833-838, 1975.

AQUINO, M.L.N.; BEZERRA, J.L.; LIRA, M.A. Ocorrência do crestamento do girassol (Helianthus annuus L.) em Pernambuco. Revista de Agricultura, Piracicaba, v. 46, n.4, p.151$156,1971$. 
ASSOCIATION OF OFFICIAL SEED ANALYSTS. Seed vigor testing commitee. Seed vigor testing handbook. East Lansing: AOSA, 1983. 88p.

BACKES, R.L. et al. Desempenho de cultivares de girassol em duas épocas de plantio de safrinha no planalto norte catarinense. Scientia Agricola, v.9, n.1, p.41-48, 2008. Disponível em: http://ojs.c3sl.ufpr.br/ojs2/index.php/agraria/article/view/10131/8174.

BAlla, A.; CASTIGLIONI, V.B.R.; CASTRO, C. Colheita do girassol. Londrina: EmbrapaCNPSo, p. 25, 1997.

BAUDET, L.M.L. Armazenamento de sementes. In: PESKE, S.T.; ROSENTAL, M.D.; ROTA, G.R. Sementes: fundamentos científicos e tecnológicos. Pelotas: UFPEL, 2003. p.370-418.

BEWLEY, J.D.; BLACK, M. Seeds: physiology of development and germination. 2.ed. New York: Plenum Press, 1994. 445p.

BRASIL. Regras para análise de sementes. Ministério da Agricultura, Pecuária e Abastecimento. Secretaria de Defesa Agropecuária. Brasília, DF: Mapa/ACS, 2009. 399p.

CARSON, M.L. Effects of leaf blight caused by Alternaria helianthi on sunflower seed yields and other agronomic traits. Phytopathology, St. Paul, v. 72, n. 7, p. 984-985, 1982.

CARVAlHO, N.M.; NAKAGAWA, J. (Eds.). Sementes: ciência, tecnologia e produção. Jaboticabal: FUNEP, 2000. 588p.

CAStro, C.; CAStigliOni, V.B.R.; BAllA, A. A cultura do girassol. Circular Técnica, EMBRAPA-CNPSo, n.13, 1996 b, 38p.

CASTRO, C. de.; CASTIGLIONI, V.B.R.; BALlA, A.; LEITE, R.M.V.B.C.; KARAM, D.; MELlO, H.C.; GUEDES, L.C.A.; FARIAS, J.R.B.A. A cultura do girassol. Londrina: EMBRAPA-CNPSo, 1997. 36p. 
CASTRO, C. de; FARIAS, J.R.B. Ecofisiologia do girassol. In: LEITE, R.M.V.B de C. et al. Girassol no Brasil. Londrina: Embrapa soja, 2005. p.163-218

CHANNAKESHAVA, B.C.; CHIKKADEVAIAH, SOMASEKHARA, K. Influence of seed treatment and seed packaging containers on seed quality and storability of hybrid sunflower. In: International Sunflower Conference, 15., Toulouse, França, 2000. Proceedings. Toulouse, França, v.2, p.F34-F37, 2000.

CONAB. Companhia Nacional de Abastecimento. Brasília. Disponível em: http://www.conab.gov.br/OlalaCMS/uploads/arquivos/15_09_11_10_42_03_boletim_graos_sete mbro_2015.pdf Acesso em: 17 de fevereiro de 2016.

COSTA, V.C.A.; SILVA, F.N.; RIBEIRO, M.C.C. Efeito de épocas de semeadura na germinação e desenvolvimento em girassol (Helinathus annuus L.). Revista Científica Rural, 5, p.154-158, 2000.

DAVET, P.; PÉRÈS, A.; REGNAULT, Y.; TOURVIEILLE, D.; PENAUD, A. Les maladies du tournesol. Paris: CETIOM, 1991. 72p.

DELOUCHE, J.C. Germinação, deterioração e vigor de sementes. Seed News, v.6, n.6, p.24-31. 2002.

DIOS, C.A. Cosecha In: AMARO, E. Producción de Girasol. Buenos Aires. Asociación Argentina de Consorcios Regionales de Experimentación Agrícola, p. 99-106, 1994.

EITEN, G. Vegetação do Cerrado. In: PINTO, M. N. Cerrado. Brasília, DF: Universidade de Brasília, 1993. p.17-73.

EMBRAPA, Agência de Informação. Bioma Cerrado. 2011. Disponível em: <http://www.agencia.cnptia.embrapa.br/Agencia16/AG01/Abertura.html>. Acesso em: 17 fev. 2016. 
FALEIRO, F.G.; GAMA, L.C.; FARIAS NETO, A.L. de F.; SOUSA, E. dos S. de. O Simpósio Nacional sobre o Cerrado e o Simpósio Internacional sobre Savanas Tropicais. In: FALEIRO, F. G.; NETO, A. L. F. (Eds.). Savanas: desafios e estratégias para o equilíbrio entre sociedade, agronegócio e recursos naturais. Planaltina, DF: Embrapa Cerrados, 2008. p.32-46.

FAOSTAT. FAO Statistical Databases. Disponível em: http://faostat.fao.org/ Acesso em: 17 fev. 2016.

FREE, J. B. Insect pollination of crops. 2. ed., London: Academic Press, 1993. 684p.

HALDER, S.; GUPTA, K. Effect of storage of sunflower seeds in high and low relative humidity on soluble leaching and internal biochemical changes. Seed Science and Technology, Zürich, v.8, p.317-321, 1980.

FRIGERI, T. Interferência de patógenos nos resultados dos testes de vigor em sementes de feijoeiro. 2007. 77f. Dissertação (Mestrado em Agronomia). Faculdade de Ciências Agrarias e Veterinarias. Universidade Estadual Paulista-UNESP, Jaboticabal, 2007.

IBGE, 2004. Mapa de biomas do Brasil: primeira aproximação. Rio de Janeiro: IBGE, 2004. Escala 1: 5.000.000. Disponível em: http://mapas.ibge.gov.br/biomas2/viewer.htm. Acesso em: 17 fev. 2016.

LAZARATO, J.; ROESSING A.C.; MELLO H.C. O agronegócio do girassol no mundo e no Brasil. In : Leite, R. M. V. B. de C.; Brighenti, A. M.; Castro, C. (Eds.). Girassol no Brasil. Londrina: Embrapa Soja, 2005. p.15-42.

LEITE, R.M.V.B.C. Doenças do girassol. Londrina: Embrapa-CNPSo, 1997. 68p.

LEITE, R.M.V.B.C.; BRIGHENTI, A.M.; CASTRO, C. de. (Eds.). Girassol no Brasil. Londrina: Embrapa Soja, 2005. 613p.

LEITE, R.M.V.B.C. Manejo de doenças do girassol. In: LEITE, R. M. V. B. C.; BRIGHENTI, A. M.; CASTRO, C. de. (Eds.). Girassol no Brasil. Londrina: Embrapa Soja, 2005. p.501-546. 
LIMA, J.E.F.W.; SANO, E.E.; SILVA, E.M. da; LOPES, T.S.S. Irrigação por pivô-central no Cerrado: levantamento da área irrigada elaborado com base na análise de imagens de satélite. Revista ITEM - Irrigação e Tecnologia Moderna, n. 83/84, p. 38-44, 2009.

MACEDO, J. Os solos da região dos Cerrados. In: ALVARES V.V.H.; FONTES, L.E.F.; FONTES, M. P. F. (Eds.). O solo nos grandes domínios morfoclimáticos do Brasil e o desenvolvimento sustentado. Viçosa: SBCS/UFV, 1996. p.135-155.

MALDANER, I. C. Irrigação e aplicação de fungicida na ocorrência de doenças e produtividade do girassol. 2009. 93f. Dissertação (Mestrado em Engenharia Agrícola) Universidade Federal de Santa Maria, Santa Maria, RS, 2009.

MARCOS FILHO, J. Fisiologia de sementes de plantas cultivadas. Piracicaba: FEALQ, 2005. $495 \mathrm{p}$.

MARCOS-FILHO, J.; AMORIM, H.V.; SILVAROLA, M.B.; PESCARIN, H.M.C. Relação entre germinação, vigor e permeabilidade das membranas celulares durante a maturação de sementes de soja. In: SEMINÁRIO NACIONAL DE PESQUISA DE SOJA, 2., 1981, Brasília. Anais. Londrina: EMBRAPA/ CNPSo, 1982. p.676-683.

MENTEN, J.O.M. Diagnóstico da patologia de sementes de girassol no Brasil. Revista Brasileira de Sementes, Londrina, v. 7, n. 1, p.25-30, 1985.

MORAES, S.A.; UNGARO, M.R.G.; MENDES, B.M.J. Alternaria helianthi agente causal de doença em girassol. Campinas: Fundação Cargill, 1983. 20p.

OLIVEIRA, M. F.; CASTIGLIONI, V.B.R.; CARVALHO, C.G.P. Melhoramento do girassol. In: LEITE, R. M. V. B.; BRIGHENTI, A. M.; CASTRO, C. (Eds.). Girassol no Brasil. Londrina: Embrapa Soja, 2005. p.269-297.

PELEGRINI, B. Girassol: uma planta solar que das Américas conquistou o mundo. São Paulo: Ícone, $1985.117 \mathrm{p}$.

POLLOCK, B.M.; ROOS, E.E. Fisiologia da semente. Brasília: AGIPLAN, 1972. 289p. 
PROENÇA, C.; OLIVEIRA, R.S.; SILVA, A.P. Flores e frutos do cerrado. Brasília, DF: UnB, 2002. 226p.

RESENDE, M.; CURI, N.; REZENDE, S.B. de; CORRÊA, G.F. Pedologia: base para distinção de ambientes. 4. ed. Viçosa: NEPUT, 2002. 338p.

RIBEIRO, J.F.; WALTER, B.M.T. Fitofisionomias do Bioma Cerrado. In: SANO, S.M.; ALMEIDA, S.P. (Eds.). Cerrado: ambiente e flora. Planaltina, DF: Embrapa Cerrados, 1998. p.87-166.

ROSSI, R.O. Girassol. Curitiba: Tecnoagro, 1998. 333p.

SCHIMIDT, E.; SILVA, P.R.F da. Efeito da densidade e arranjo de plantas de girassol. II características agronômicas e interceptação de radiação solar. Pesquisa Agropecuária Brasileira, Brasília, v.21, n.8, p.853-863, 1986.

SETTE, D.M. Os climas do Cerrado do Centro-Oeste. Revista Brasileira de Climatologia, v.1, p.29-42, 2004.

SILVA, M.L.O.; FARIA, M.A.; PEREIRA, R.; SANTANA, M.J.; WESLEY, M. Viabilidade técnica e econômica do cultivo de safrinha do girassol irrigado na região de Lavras, MG. Ciência e Agrotecnologia, v. 31, n.1, p.200-205, 2007.

SILVEIRA, J.M. Fenología y calidad de semillas de girasol (Helianthus annuus L.). 2000. 244f. Tesis (Doctoral Producción Vegetal, Fitotecnia) - Escuela Técnica Superior de Ingenieros Agrónomos, Universidad Politécnica de Madrid.

SKORIC, D. Achievements and future directions of sunflower breeding. Field Crops Research, Amsterdam, v.30, p.231-270, 1992.

TANAKA, M.A. Doenças do girassol. Informe Agropecuário, Belo Horizonte, v.7, n.82, p.84$86,1981$.

UNGARO, M.R.G. Girassol (Helianthus annuus L.). In: Boletim Informativo do Instituto Agronômico, Campinas, v.200, n.5, p.112-113, 1990. 
VIEIRA, O.V. Validação e difusão de tecnologia para produção de girassol no Brasil. In: HOFFMANN-CAMPO, C. B.; SARAIVA, O. F. (Org). Resultados de pesquisa da Embrapa Soja - 2000: girassol e trigo. Londrina: Embrapa Soja, 2001. p.27-29.

VIEIRA, R.D.; PENARIOL, A.L.; PERECIN, D.; PANOBIANCO, M. Condutividade elétrica e teor de água inicial das sementes de soja. Pesquisa Agropecuária Brasileira, v.37, n.9, p.1333$1338,2002$.

VILLA, L. G.; ROA, G. Secagem e armazenamento da soja industrial e sementes a granel. Campinas: Fundação Cargill, 1979. 64p.

ZIMMER, D.E.; HOES, J.A. Diseases. In: CARTER, J.F. (Eds.). Sunflower science and technology. Madison: American Society of Agronomy, 1978. p.225-262.

ZIMMERMAN, D. C. \& ZIMMER, D. E. Influence of harvest date and freez-ing on sunflower seed germination. Crop Science, 18:479-481, 1978. 


\section{CAPÍTULO I}

ESTIMATIVAS DE PARÂMETROS GENÉTICOS, CORRELAÇÕES FENOTÍPICAS, GENOTÍPICAS E AMBIENTAIS E VARIABILIDADE GENÉTICA EM GIRASSOL NO CERRADO

ESTIMATES OF GENETIC PARAMETERS, PHENOTYPIC, GENOTYPIC AND ENVIRONMENTAL CORRELATIONS AND GENETIC VARIABILITY ON SUNFLOWER IN THE BRAZILIAN SAVANNAH 


\section{ESTIMATIVAS DE PARÂMETROS GENÉTICOS, CORRELAÇÕES FENOTÍPICAS, GENOTÍPICAS E AMBIENTAIS E VARIABILIDADE GENÉTICA EM GIRASSOL NO CERRADO}

\subsection{RESUMO}

Este trabalho teve por fim estimar parâmetros genéticos, fenotípicos e ambientais dos caracteres rendimento (REND), dias para a floração (DFI) com base na data de florescimento em R5, tamanho do capítulo (TC), peso de mil aquênios (PMA), altura (ALT) e teor de óleo (ÓLEO), em 16 genótipos de girassol no bioma Cerrado. O experimento foi realizado na área experimental da Embrapa Cerrados, em Planaltina, DF, situada a 15' 35' 30" de latitude Sul, $47^{\circ} 42^{\prime} 30^{\prime \prime}$ de longitude Oeste e a altitude de $1.007 \mathrm{~m}$, em solo classificado LATOSSOLO VERMELHO Distrófico típico, argiloso. O delineamento experimental utilizado foi de blocos ao acaso com quatro repetições. Com exceção do caráter tamanho de capítulo, a variância genética foi o principal componente da variância fenotípica entre os genótipos, evidenciando alta variabilidade genética e eficiência experimental, com controle correto do ambiente. Em valores absolutos, as correlações genotípicas foram superiores às fenotípicas e ambientais. Os altos valores encontrados para herdabilidade e acurácia seletiva indicam eficiência da seleção fenotípica. Os resultados evidenciam alta variabilidade genética entre os genótipos avaliados, o que pode contribuir para o melhoramento genético de girassol.

Palavras-chave: Helianthus annuиs L., diversidade genética, recursos genéticos, fenotípico, correlações genéticas. 


\section{ESTIMATES OF GENETIC PARAMETERS, PHENOTYPIC, GENOTYPIC AND ENVIRONMENTAL CORRELATIONS AND GENETIC VARIABILITY ON SUNFLOWER IN THE BRAZILIAN SAVANNAH}

\subsection{ABSTRACT}

This study aims to estimate genetic, phenotypic and environmental parameters of the following characters: grain yield (REND), days to start flowering (DFI), chapter length (TC), weight of a thousand achenes (PMA), plant height (ALT) and oil content (ÓLEO) of 16 sunflower genotypes in the Savannah of Central Brazil. The experiment was conducted at Embrapa Cerrados (Federal District - Brazil) located at 15० 35' 30" S latitude, $47^{\circ} 42^{\prime} 30^{\prime \prime} \mathrm{W}$ longitude and $1.007 \mathrm{~m}$ above sea level, in soil classified as dystroferric Oxisol. A complete randomized block design with four replicates was used. Except for the character chapter length, genetic variance was the main component of the phenotypic variance among the genotypes, indicating high genetic variability and experimental efficiency with proper environmental control. In absolute terms, the genetic correlations were superior to phenotypic and environmental. The high values found for heritability and selective accuracy indicate efficiency of phenotypic selection. The results showed high genetic variability among genotypes, which may contribute to the genetic improvement of sunflower.

Key words: Helianthus annuиs L., genetic diversity, genetic resources, phenotypic, genotypic correlations. 


\subsection{INTRODUÇÃO}

O girassol (Helianthus annuus L.) é uma cultura anual que se destaca pela produção de óleo de alta qualidade. O melhoramento genético de girassol no Brasil tem por objetivo a busca por materiais precoces (OLIVEIRA et al., 2005), de porte baixo, com alta produtividade e resistentes a condições abióticas e bióticas, visando o uso da cultura durante a entressafra. Aliadas à seleção de genótipos mais adaptados, várias práticas contribuem para o aumento do rendimento da cultura como a adequação dos genótipos à época de semeadura (AMABILE et al., 2007).

Para auxiliar a condução de estudos em programas de melhoramento, existem ferramentas importantes como a quantificação da variabilidade e extensão com que os caracteres são herdados. Para tanto, faz-se uso da estimativa de parâmetros genéticos, que geram conhecimento de alto valor para a pesquisa.

As correlações são utilizadas para auxiliar a seleção, especialmente quando há um caráter de interesse que possui baixa herdabilidade ou difícil aferição. Segundo Santos e Vencovsky (1986), as correlações também são úteis para obter eficiência na seleção simultânea de características.

Para obter uma seleção eficiente, é preciso estimar os componentes de variância genética e fenotípica, pois através da relação entre as variâncias, é possível estimar a acurácia e a herdabilidade. Tais estimativas contribuem para a efetividade das inferências das médias genotípicas a partir das fenotípicas (RESENDE; DUARTE, 2007).

A herdabilidade e a acurácia são importantes para o planejamento de estudos e ensaios em programas de melhoramento, pois permitem concluir informações sobre caracteres, especialmente para aqueles mais influenciados pelo ambiente. Com isso, é possível a busca por uma seleção eficaz (CRUZ et al., 2004).

A busca por genótipos mais adaptados e conhecimento a partir de dados genéticos deve ser constante, a fim de auxiliar o desenvolvimento de pesquisas. Estudos a respeito da variabilidade genética geram dados importantes para programas de melhoramento, servindo como base para desenvolvimento e seleção de materiais superiores. 
Estimativas de parâmetros genéticos e estatísticos a respeito da cultura do girassol refletem informações de alto valor para a pesquisa de melhoramento da espécie. O presente trabalho teve por objetivo a obtenção de informações acerca de genótipos de girassol no Cerrado brasileiro, a partir de estimativas de parâmetros genéticos, fenotípicos e ambientais relacionadas aos componentes de produção e caracteres agromorfológicos da cultura.

\subsection{MATERIAL E MÉTODOS}

O experimento foi realizado no Cerrado do Distrito Federal, na área experimental da Embrapa - Centro de Pesquisa Agropecuária dos Cerrados, em Planaltina, DF, situada a 15 35' $30 "$ de latitude Sul, 47 42' 30" de longitude Oeste e a altitude de $1.007 \mathrm{~m}$, em solo classificado como LATOSSOLO VERMELHO Distrófico típico, argiloso. Foram realizadas análises de solo avaliando três camadas: $0-10 \mathrm{~cm} ; 10-20 \mathrm{~cm}$; e $20-40 \mathrm{~cm}$, conforme indicado na tabela 1 .

Durante o experimento, dados meteorológicos foram coletados na Estação Meteorológica da Embrapa Cerrados, a saber: temperatura mínima, média e máxima do ar de $8,4{ }^{\circ} \mathrm{C}, 20,74{ }^{\circ} \mathrm{C}$ e $30,8{ }^{\circ} \mathrm{C}$, respectivamente; umidade média do ar de 73,22\%; e um somatório de 479,7 mm de chuva durante o período do ensaio.

A semeadura do ensaio ocorreu em fevereiro de 2014. Dezesseis genótipos foram avaliados: CF 101, ADV 5504, BRS G42, M734, HELIO 250, SYN 3950HO, BRS 323, MG 360, GNZ NEON, HLA 2012, MG 305, HELIO 251, AGUARÁ 06, AGUARÁ 04, PARAISO 20 e SYN 045. O genótipo M734 foi utilizado como testemunha. O delineamento experimental utilizado foi de blocos ao acaso com quatro repetições. As parcelas continham quatro linhas de 5 metros de comprimento, com espaçamento de $0,8 \mathrm{~m}$ entre linhas. A área útil da parcela foi de 8 $\mathrm{m}^{2}$ e a densidade correspondeu a 33 plantas $/ \mathrm{m}^{2}$. Foram aplicados $400 \mathrm{~kg} \mathrm{ha}^{-1}$ de 4-30-16 como adubação de base e $60 \mathrm{~kg} \mathrm{ha}^{-1}$ de $\mathrm{N}$ como adubação de cobertura.

Restos culturais foram incorporados ao solo através de arado de discos de 32'. Posteriormente usou-se uma grade niveladora de 20" para gradagem. Em pré-emergência, aplicou-se o herbicida Trifluralina na dosagem 1,2 $\mathrm{L} \mathrm{ha}^{-1}$. 
Foram avaliados os caracteres rendimento (REND) em kg ha ${ }^{-1}$, dias para a floração (DFI) com base na data de florescimento em R5, tamanho do capítulo (TC) em cm, peso de mil aquênios (PMA) em g, altura (ALT) em cm e teor de óleo (ÓLEO) em \%. Para determinação do teor de óleo foi utilizada ressonância magnética nuclear. As amostras corresponderam a sementes de aproximadamente 200 aquênios, colocadas em acessório combinado com o módulo esférico do equipamento NIR (Modelo Antaris II, Thermo Científico).

Os dados obtidos foram submetidos à análise de variância através do programa Genes (CRUZ, 1997), de acordo com o modelo estatístico Yij $=\mu+\mathrm{Gi}+\mathrm{Bj}+\varepsilon \mathrm{ij}$, sendo Yij $=$ valor observado relativo da característica da i-ésimo genótipo no j-ésimo bloco, $\mu=$ média geral, $\mathrm{Gi}=$ efeito da i-ésimo genótipo $(\mathrm{i}=1,2, \ldots, \mathrm{g}), \mathrm{Bj}=$ efeito do j-ésimo bloco $(\mathrm{j}=1,2, \ldots, \mathrm{r})$, eij $=$ erro aleatório (fatores não controlados), cij NID $\left(0, \sigma^{2}\right)$.

Por meio do programa Genes (CRUZ, 1997) foram obtidas também, para cada uma das características analisadas, as estimativas das variâncias genotípica entre os acessos $\left(\hat{\sigma}_{g}^{2}\right)$, ambiental média $\left(\hat{\sigma}_{e}^{2}\right)$ e fenotípica ao nível de média $\left(\hat{\sigma}_{f}^{2}\right)$, a herdabilidade ao nível de média ( $\left.h_{a}^{2}\right)$, os coeficientes de variação genético $\left(\mathrm{CV}_{\mathrm{g}}\right)$ e experimental $\left(\mathrm{CV}_{\mathrm{e}}\right)$, o coeficiente de correlação relativa $\left(\mathrm{CV}_{\mathrm{r}}\right)$ e a acurácia seletiva $\left(\hat{\mathrm{r}}_{\hat{g} g}\right)$, em que: Variância genotípica - $\hat{\sigma}_{g}^{2}=(\mathrm{QMg}-\mathrm{QMe}) / \mathrm{r}$; Variância ambiental $-\hat{\sigma}_{e}^{2}=\mathrm{QMe} / \mathrm{r}$; Variância fenotípica entre as médias dos tratamentos $-\hat{\sigma}_{f}^{2}=$ QMg/r; Herdabilidade ao nível de média - $h_{a}^{2}(\%)=\left(\hat{\sigma}_{g}^{2} /(\mathrm{QMg} / \mathrm{r})\right) 100 ;$ Coeficiente de variação genético $-\mathrm{CVg}=\left(100 \sqrt{\hat{\sigma}_{g}^{2}}\right) / \mathrm{m}_{\mathrm{c}}$, onde $\mathrm{m}_{\mathrm{c}}=$ média do caráter; Coeficiente de variação experimental $-\mathrm{CV}_{e}(\%)=(100 \sqrt{Q M e}) / \mathrm{m}_{\mathrm{c}}$, onde $\mathrm{m}_{\mathrm{c}}=$ média do caráter.; Coeficiente de variação relativo $-\mathrm{CV}_{r}=\sqrt{\frac{\hat{\sigma}_{g}^{2}}{\hat{\sigma}^{2}}} ;$ Acurácia seletiva $-\hat{\mathrm{r}}_{\hat{g} g}=\sqrt{1-1 / \mathrm{F}}$.

A determinação das estimativas das variâncias e covariâncias fenotípicas, genotípicas e de ambiente entre os caracteres dois a dois permite dar continuidade às avaliações através da obtenção das correlações genotípicas, fenotípicas e de ambiente, segundo Kempthorne (1966), a partir das equações: Coeficiente de correlação genotípica- $\mathrm{r}_{g}=C \hat{o} v_{g}(X, Y) / \sqrt{\hat{\sigma}_{g}^{2}}(X) \hat{\sigma}_{g}^{2}(Y)$; 
Coeficiente de correlação fenotípica - $\mathrm{r}_{f}=C \hat{o} v_{f}(X, Y) / \sqrt{ } \hat{\sigma}_{f}^{2}(X) \hat{\sigma}_{f}^{2}(Y)$; Coeficiente de correlação ambiental - $\mathrm{r}_{a}=C \hat{o} v_{a}(X, Y) / \sqrt{ } \hat{\sigma}_{a}^{2}(X) \hat{\sigma}_{a}^{2}(Y)$, em que: $C \hat{o} v_{g}(X, Y), C \hat{o} v_{f}(X, Y)$ e Côv $v_{a}(X, Y)=$ Estimadores da covariância genotípica, fenotípica e ambiental, respectivamente, entre dois caracteres $X$ e $Y, \hat{\sigma}_{g}^{2}(X), \hat{\sigma}_{f}^{2}(X)$ e $\hat{\sigma}_{a}^{2}(X)=$ Estimadores da variância genotípica, fenotípica e ambiental, respectivamente, do caráter $X$ e $\hat{\sigma}_{g}^{2}(Y), \hat{\sigma}_{f}^{2}(Y)$ e $\hat{\sigma}_{a}^{2}(Y)=$ Estimadores da variância genotípica, fenotípica e ambiental, respectivamente, do caráter $Y$. Usou-se o programa Genes (CRUZ, 1997).

Foram gerados um dendrograma e um gráfico de dispersão. O dendrograma permite a realização de análises de agrupamento. Para tanto, foi utilizado o método do UPGMA (Unweighted pair-group method arithmetic average), usando como base a matriz de distâncias genéticas (SNEATH; SOKAL, 1973). O gráfico de dispersão teve como base o uso de escalas multidimensionais e sua obtenção foi possibilitada pela metodologia das coordenadas principais e do Programa SAS (SAS INSTITUTE INC., 2008) e Statistica (STATSOFT INC., 1999).

O dendrograma foi dividido em grupos. A divisão corresponde à parada do algoritmo de aglomeração, baseada na distância genética média entre os genótipos. Com uso do programa computacional NTSYS pc 2.1 (ROHLF, 2000), o coeficiente de correlação cofenético (r) entre as distâncias genéticas originais e as representadas pelo dendograma entre os pares de genótipos foi calculado conforme Sokal e Rohlf (1962). Com isso, foi estimado o ajuste entre o dendrograma e a matriz de distâncias.

\subsection{RESULTADOS E DISCUSSÃO}

As análises de variância evidenciam o efeito significativo dos genótipos, pois, com exceção do TC, todas as variáveis foram significativas a $1 \%$ de probabilidade pelo teste $\mathrm{F}$ ( $\mathrm{p} \leq$ 0,01). Resende e Duarte (2007) consideram que o valor de F em ensaios de avaliação genotípica deve ser superior a 2,0, compatível com o encontrado no presente trabalho, evidenciando precisão. 
A qualidade experimental pode ser evidenciada a partir da interpretação de dados como os coeficientes de variação ambiental. Seguindo os critérios propostos por Pimentel-Gomes (1990), os baixos valores dos coeficientes de variação ambiental (CVe) indicam alta precisão do experimento.

Além do CVe, outras estatísticas devem ser avaliadas para que inferências sejam realizadas acerca da qualidade experimental, como é o caso do coeficiente de variação genética e da acurácia seletiva, determinantes para uma interpretação eficaz sobre o valor genotípico a partir de avaliações fenotípicas (RESENDE, 2002).

A variância genética foi o principal componente da variância fenotípica entre os genótipos, exceto para o caráter tamanho de capítulo. Para os demais, a variância genética representa mais de $85 \%$ da variância fenotípica, evidenciando alta variabilidade genética e eficiência experimental, com controle correto do ambiente, ou seja, confirma o planejamento eficaz quanto à definição das características do estudo, como tamanho da parcela e número de repetições.

Para as variáveis REND, DFI, PMA, ALT e ÓLEO, tem-se o coeficiente de variação genético superior ao $\mathrm{CVe}$, indicando caracteres favoráveis ao melhoramento. Em contraste, para TC, o valor de CVg é inferior ao de CVe, sugerindo que a seleção fenotípica para este caráter é pouco favorável. Consequentemente, o CVr para REND, DFI, PMA, ALT e ÓLEO é superior a 1, evidenciando a possibilidade de sucesso da seleção fenotípica destas características, uma vez que a variância genética supera a ambiental (SANTOS, 1985; VENCOVSKY, 1987). Apesar de CVr inferior a 1, a acurácia seletiva para TC é classificada como moderada, segundo Resende e Duarte (2007). Para os caracteres REND, DFI, PMA, ALT e ÓLEO a acurácia seletiva é considerada muito alta, o que representa, segundo Resende (2002), boa inferência do valor genotípico a partir do fenotípico, contribuindo com informações proveitosas para seleção e consequente ganho genético.

Outro parâmetro importante é a herdabilidade, que foi superior a $90 \%$ para os caracteres REND, DFI, PMA e ALT. Para ÓLEO, o valor obtido foi 85,34\% e para TC, 45,11\%. Altas estimativas de herdabilidade contribuem para o sucesso da seleção, pois indicam a possibilidade de que tais características sejam herdadas. Silva et al. (2011) observaram valores de $85 \%$ e $80 \%$ 
de herdabilidade para os caracteres DEM (dias da emergência a maturação) e EST (estatura em $\mathrm{cm})$, respectivamente, coerentes com o encontrado neste estudo, evidenciando alta possibilidade de seleção para tais características. Assim como o presente trabalho, Guerra \& Grzeidak (2011) apresentaram valores superiores a $80 \%$ para os caracteres rendimento, floração e altura. Amorim et al., (2007) observaram herdabilidade de 87,90\% para estatura de plantas e 94\% para início da floração. Para TC, tal como neste trabalho, Silva et al. (2011) encontraram, baixa herdabilidade (23\%), apontando a maior facilidade de esta característica ser alterada pelo ambiente. Khan et al. (2007) obtiveram herdabilidades de 51\% para TC, 86\% para PMA e 98\% para ÓLEO. Rehman et al. (2012) encontraram 13,1\%, 95,2\% e 51\% para TC, DFI e ÓLEO, respectivamente.

As altas herdabilidades encontradas no presente estudo apontam no sentido da elevada eficiência da seleção fenotípica para os caracteres estudados. Considerando o observado pelos parâmetros estatísticos, pode-se dizer também que houve correto controle de fatores ambientais, possibilitando a expressão da variabilidade genotípica.

Com referência à importância relativa dos caracteres para a divergência morfoagronômica dos acessos de girassol, estudados neste trabalho, segundo Singh (1981), as características com maior influência foram dias de floração (DFI), e o rendimento (REND), perfazendo 91,41\% e $5,34 \%$ da variação total, respectivamente. No outro extremo, verificou-se que o tamanho do capitulo (TC) com $0,07 \%$ e a altura (ALT) com 0,57\% foram os que menos contribuíram (Tabela 2).

As correlações genotípicas, em valores absolutos, foram superiores às fenotípicas e ambientais. Em decorrência deste fato, pode-se dizer que o fenótipo reflete o genótipo, uma vez que os fatores genéticos estudados contribuíram mais quando comparados ao ambiente. Coeficientes fenotípicos e genotípicos com o mesmo sinal indicam ausência de erros na amostragem e avaliação, de acordo com Cruz et al. (2004).

Para os pares de caracteres REND e DFI, REND e TC, REND e PMA, REND e ÓLEO, DFI e PMA, DFI e ÓLEO, TC e PMA, TC e ALT, PMA e ALT e ALT e ÓLEO houve diferença de sinais entre as correlações genotípicas e ambientais, o que pode significar que o ambiente favoreceu uma característica em detrimento da outra. 
O par DFI e ALT deteve as maiores correlações genotípica $(0,9362)$ e fenotípica $(0,8996)$, determinando que uma característica influencia a outra em mesmo sentido. O mesmo ocorreu com o par REND e ALT, que apresentou as segundas maiores correlações genotípica $(0,5497)$ e fenotípica (0,5324). Para ambos os pares, a correlação ambiental apresentou o mesmo sinal das correlações genotípica e fenotípica, indicando que o ambiente não influenciou as variáveis. Com isso, é possível realizar seleção indireta. É possível prever que cultivares com plantas mais altas irão apresentar florescimento mais tardio, o que não é interessante do ponto de vista da pesquisa por melhoramento genético de girassol, que busca genótipos com menor ciclo, com foco no uso para entressafra. De acordo com estes resultados, também se pode dizer que cultivares com plantas mais altas terão maior rendimento. Silva et al. (2011) observaram correlações positivas para os pares estatura e rendimento, estatura e dias da floração a maturação (DFM) e estatura e dias da emergência a maturação (DEM). Rehman et al. (2012) encontraram correlações genotípicas e fenotípicas de 0,754 e 0,698, nesta ordem, para o par DFI e ALT.

O valor do coeficiente de correlação cofenética do dendrograma foi 0,74 , considerado de boa magnitude, estando acima do valor de 0,70, indicado por Rohlf (2000). Este resultado possibilita a realização de inferências através de análise visual do dendrograma (Figura 1), pois indica coerência de ajuste entre a representação gráfica das distâncias genéticas e da matriz inicial.

Constataram-se dois grandes grupos pela análise de agrupamento, com um ponto de corte definido à média de 270. Observou-se proximidade entre os genótipos BRS G42 e BRS 323, ambos provenientes da Embrapa e com parentais comuns. O conhecimento das distâncias entre genótipos pode ser de grande utilidade para programas de melhoramento.

O gráfico de dispersão (Figura 2), assim como o dendrograma, indica variabilidade dos materiais avaliados. A dissimilaridade genética observada aponta opções potenciais para incrementar e amplificar a base genética de projetos relacionados a programas de melhoramento. 


\subsection{CONCLUSÕES}

As características avaliadas para a cultura do girassol no Cerrado obtiveram efeitos genéticos significativos. A variância genética foi o principal componente da variância fenotípica entre os genótipos, salvo para o caráter tamanho de capítulo. Em valores absolutos, as correlações genotípicas foram superiores às fenotípicas e ambientais.

A seleção é favorecida para as características avaliadas, conforme indicado pelos altos valores de coeficiente de variação genética, acurácia seletiva e herdabilidade.

Observa-se alta variabilidade genética entre os genótipos avaliados, com potencial uso em programas de melhoramento genético. 


\subsection{TABELAS E FIGURAS}

Tabela 1. Resultados das análises do solo das camadas $0-10 \mathrm{~cm}, 10-20 \mathrm{~cm}$ e $20-40 \mathrm{~cm}$. Embrapa Cerrados, Planaltina, DF, 2014.

\begin{tabular}{c|c|c|c|c|c|c|c|c|c} 
Amostras & $\begin{array}{c}\mathrm{Al}- \\
\text { trocável } \\
\left(\mathrm{mmol}_{\mathrm{c}} \mathrm{dm}^{-3}\right)\end{array}$ & $\begin{array}{c}\mathrm{Ca} \\
\left(\mathrm{mmol}_{\mathrm{c}} \mathrm{dm}^{-3}\right)\end{array}$ & $\begin{array}{c}\mathrm{H}+\mathrm{Al} \\
\left(\mathrm{mmol}_{\mathrm{c}} \mathrm{dm}^{-3}\right)\end{array}$ & $\begin{array}{c}\mathrm{K} \\
\left(\mathrm{mmol}_{\mathrm{c}} \mathrm{dm}^{-3}\right)\end{array}$ & $\begin{array}{c}\text { Matéria } \\
\text { Orgânica } \\
\left(\mathrm{g} \mathrm{dm}^{-3}\right)\end{array}$ & $\begin{array}{c}\mathrm{Mg} \\
\left(\mathrm{mmol}_{\mathrm{c}} \mathrm{dm}^{-3}\right)\end{array}$ & $\begin{array}{c}\mathrm{pH} \\
\mathrm{em} \\
\text { água }\end{array}$ & $\begin{array}{c}\mathrm{pH} \\
\mathrm{em} \\
\mathrm{CaCl}_{2}\end{array}$ & $\begin{array}{c}\mathrm{P} \\
\left(\mathrm{mg} \mathrm{dm}^{-3}\right)\end{array}$ \\
\hline $0-10 \mathrm{~cm}$ & 1,18 & 23,7 & 59,28 & 7,7 & 33,87 & 7,8 & 5,76 & 4,93 & 39,87 \\
$10-20 \mathrm{~cm}$ & 1,50 & 22,1 & 61,31 & 5,6 & 31,83 & 6,0 & 5,56 & 4,81 & 40,95 \\
$20-40 \mathrm{~cm}$ & 0,24 & 21,5 & 36,34 & 3,9 & 26,45 & 6,2 & 5,88 & 5,30 & 6,23
\end{tabular}

Tabela 2. Quadrados médios de genótipos $(\mathrm{QMg})$ e do erro $(\mathrm{QMe})$, valor de $\mathrm{F}$ e estimativas das variâncias fenotípica a nível de média $\left(\sigma_{\mathrm{f}}^{2}\right)$, genotípica $\left(\sigma_{\mathrm{g}}{ }^{2}\right)$ e ambiental $\left(\sigma_{\mathrm{e}}{ }^{2}\right)$, da herdabilidade ao nível de média $\left(h_{a}^{2}\right)$, dos coeficientes de variação experimental $(\mathrm{CVe})$ e genético $(\mathrm{CVg})$, da relação $\mathrm{CVr}$ e da acurácia $\left(\hat{\mathbf{r}}_{\hat{g} g}\right)$ de cada caráter avaliado em 16 genótipos de girassol. Embrapa Cerrados, Planaltina, DF, 2014.

\begin{tabular}{|c|c|c|c|c|c|c|}
\hline $\begin{array}{l}\text { Parâmetros } \\
\text { Genéticos }\end{array}$ & REND & DFI & TC & PMA & ALT & ÓLEO \\
\hline QMg & 536676,81 & 546,92 & 3,28 & 327,09 & 953,81 & 47,15 \\
\hline QMe & 8739,50 & 0,48 & 1,80 & 17,82 & 72,47 & 6,91 \\
\hline $\mathbf{F}$ & $61,41 * *$ & $1147,23^{* *}$ & 1,82 & $18,36^{* * *}$ & $13,16^{* *}$ & $6,82 * *$ \\
\hline$\sigma_{f}^{2}$ & 134169,20 & 136,73 & 0,82 & 81,77 & 238,45 & 11,79 \\
\hline$\sigma_{\mathrm{g}}{ }^{2}$ & 131984,33 & 136,61 & 0,37 & 77,32 & 220,33 & 10,06 \\
\hline$\sigma_{e}^{2}$ & 2184,88 & 0,12 & 0,45 & 4,45 & 18,12 & 1,73 \\
\hline$h_{a}^{2}(\%)$ & 98,37 & 99,91 & 45,11 & 94,55 & 92,40 & 85,34 \\
\hline Cve (\%) & 2,94 & 1,25 & 8,27 & 7,68 & 4,55 & 5,87 \\
\hline $\operatorname{CVg}(\%)$ & 11,44 & 21,18 & 3,75 & 15,99 & 7,93 & 7,08 \\
\hline $\operatorname{CVr}(\%)$ & 38.86 & 16,93 & 0,45 & 2,08 & 1,74 & 1,21 \\
\hline$\hat{\mathrm{r}}_{\hat{g} g}$ & 0,99 & 0,99 & 0,67 & 0,97 & 0,96 & 0,92 \\
\hline CRDG $(\%)^{2}$ & 5,34 & 91,41 & 0,07 & 1,52 & 0,57 & 1,09 \\
\hline
\end{tabular}


Tabela 3. Estimativas dos coeficientes de correlação genotípica, fenotípica e ambiental entre os caracteres de REND (rendimento de grãos), DFI (Dias para Floração), TC (Tamanho do capítulo), PMA (Peso de mil aquênios), ALT (Altura de planta), ÓLEO (Teor de óleo) em 16 genótipos de girassol. Embrapa Cerrados, Planaltina, DF, 2014.

\begin{tabular}{|c|c|c|c|c|c|c|}
\hline Caracteres & Correlações & DFI & TC & PMA & ALT & OLEO \\
\hline \multirow{3}{*}{ REND } & $r_{g}$ & 0,4227 & 0,5593 & $-0,0484$ & 0,5497 & $-0,2090$ \\
\hline & $r_{f}$ & 0,4190 & 0,3651 & $-0,0427$ & $0,5324 *$ & $-0,1833$ \\
\hline & $r_{a}$ & $-0,0385$ & $-0,0790$ & 0,1349 & 0,2360 & 0,1668 \\
\hline \multirow{3}{*}{ DFI } & $r_{g}$ & & 0,6126 & 0,1151 & 0,9362 & $-0,3268$ \\
\hline & $\mathrm{r}_{\mathrm{f}}$ & & 0,4141 & 0,1114 & $0,8996 * *$ & $-0,2992$ \\
\hline & $r_{a}$ & & 0,1308 & $-0,0732$ & 0,0048 & 0,2237 \\
\hline \multirow{3}{*}{ TC } & $r_{g}$ & & & $-0,0593$ & 0,6961 & $-0,0419$ \\
\hline & $\mathrm{r}_{\mathrm{f}}$ & & & $-0,0224$ & 0,4469 & $-0,0521$ \\
\hline & $r_{a}$ & & & 0,0940 & $-0,0124$ & $-0,0921$ \\
\hline \multirow{3}{*}{ PMA } & $r_{g}$ & & & & $-0,0681$ & $-0,2073$ \\
\hline & $r_{f}$ & & & & $-0,0528$ & $-0,1910$ \\
\hline & $r_{a}$ & & & & 0,1688 & $-0,0527$ \\
\hline \multirow{3}{*}{ ALT } & $r_{g}$ & & & & & $-0,5109$ \\
\hline & $\mathrm{r}_{\mathrm{f}}$ & & & & & $-0,4500$ \\
\hline & $r_{a}$ & & & & & 0,0346 \\
\hline
\end{tabular}




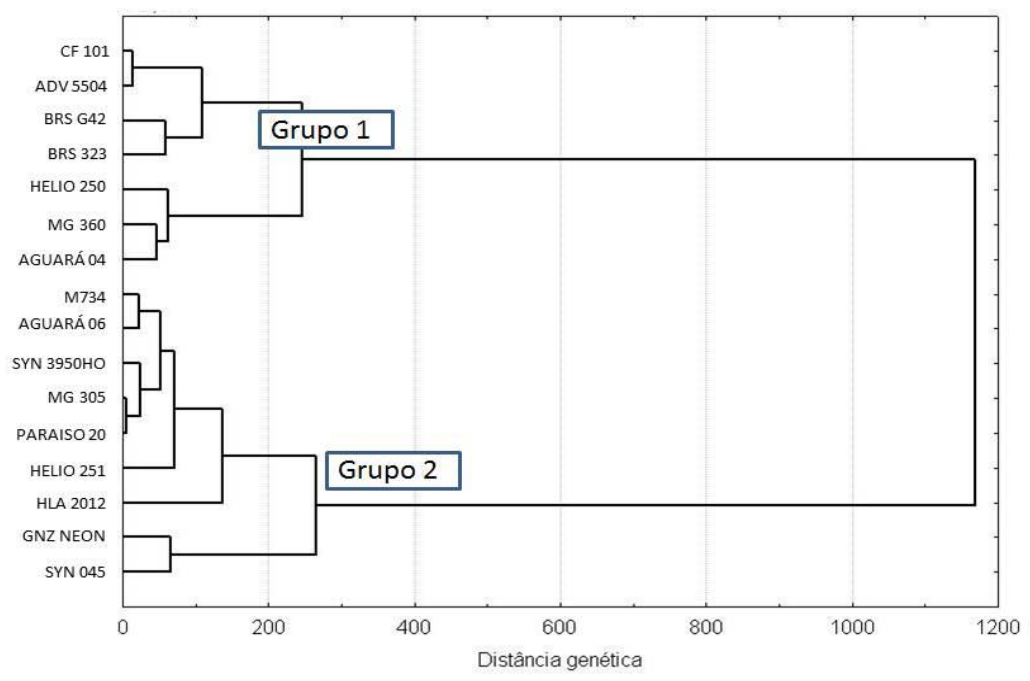

Figura 1. Análise de agrupamento de 16 genótipos de girassol, utilizando seis caracteres. O método do UPGMA foi usado como critério de agrupamento. $\mathrm{O}$ valor do coeficiente de correlação cofenética foi de 0,74 .

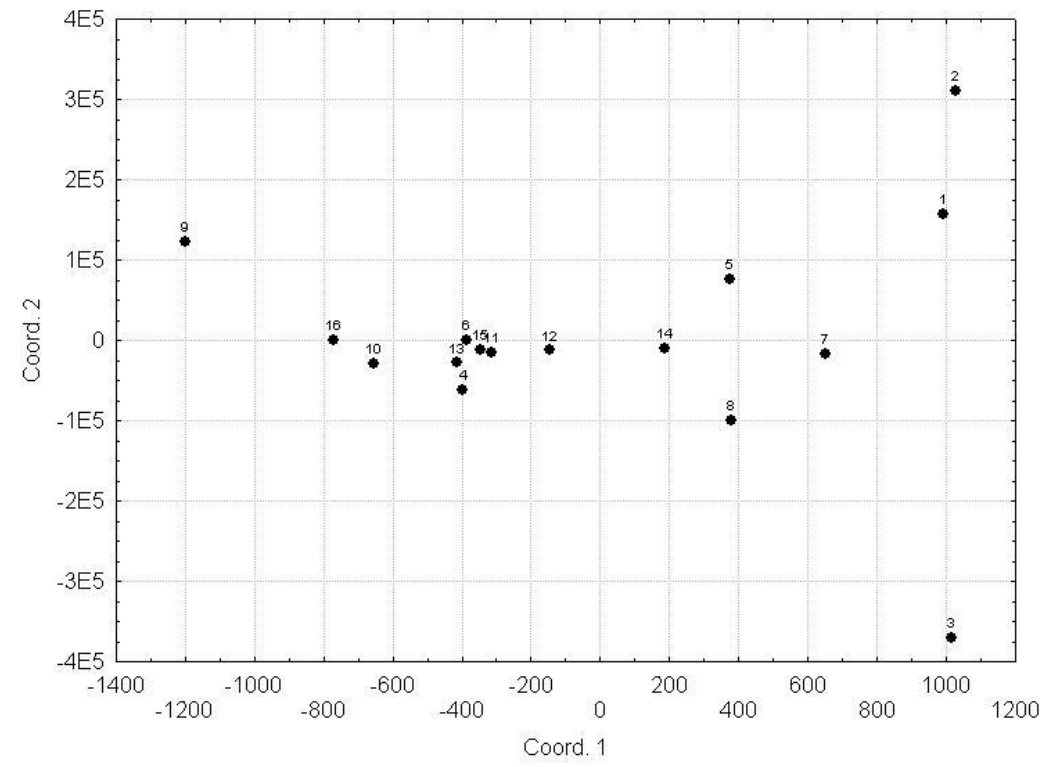

Figura 2. Dispersão gráfica de 16 genótipos de girassol utilizando seis características. Os números correspondem, na ordem de 1 a 16, aos genótipos CF 101, ADV 5504, BRS G42, M734, HELIO 250, SYN 3950HO, BRS 323, MG 360, GNZ NEON, HLA 2012, MG 305, HELIO 251, AGUARÁ 06, AGUARÁ 04, PARAÍSO 20 e SYN 045, respectivamente. 


\subsection{REFERÊNCIAS BIBLIOGRÁFICAS}

AMABILE, R. F.; MONTEIRO, V. A.; AQUinO, F. D. V. de; CARVAlho, C. G. P. de; RIBEIRO JÚNIOR, W. Q.; FERNANDES, F. D.; SANTORO, V. L. Avaliação de genótipos de girassol em safrinha no Cerrado do Distrito Federal. In REUNIÃO NACIONAL DE PESQUISA DE GIRASSOL, 17., 2007. Uberaba. Anais. Londrina: Embrapa Soja, 2007. p.109-112.

AMORIM, E.P.; RAMOS, N.P.; UNGARO, M.R.G.; KIIH, T.A.M. Divergência genética em genótipos de girassol. Ciência e Agrotecnologia, v.31, n.6, p.1637-1644, 2007.

CRUZ, C.D.; REGAZZI, A.J.; CARNEIRO, P.C.S. Modelos biométricos aplicados as melhoramento genético. 3.ed. Viçosa: UFV, 2004. v.1, 480p.

CRUZ, C.D. Programa Genes: aplicativo computacional em genética e estatística. Versão Windows - 2007. Viçosa: editora UFV, 1997. v.1. 442p.

GUERRA, E.P.; GRZEIDAK, C.H. Avaliação de genótipos de girassol na região de Curitiba-PR. In: $19^{\circ}$ Reunião Nacional de Pesquisa do Girassol, $7^{\circ}$ Simpósio Nacional sobre a Cultura do Girassol. Aracaju, 2011.

KHAN, H.; MUHAMMAD, S.; SHAH, R.; IQBAL, N. Genetic analysis of yield and some yield components in sunflower. Sarhad J. Agriculture, v.23, n4, p.985-990, 2007.

KEMPTHORNE, O. An introduction to genetic statistics. New York: John Wiley \& Sons, 1966. $545 \mathrm{p}$.

OLIVEIRA, M. F.; CASTIGLIONI, V.B.R.; CARVALHO, C.G.P. Melhoramento do girassol. In: LEITE, R. M. V. B.; BRIGHENTI, A. M.; CASTRO, C. (Eds.). Girassol no Brasil. Londrina: Embrapa Soja, 2005. p.269-297.

PIMENTEL-GOMES, F. Curso de estatística experimental. 13. ed. Piracicaba: Nobel, 1990. 468p. 
REHMAN, R.; ARSHAD, M.; KHAN, M.A.; MOHMAND, A.S.; SHABBIR, G.; SHAH, M.K.N. Using multivariate analysis for selecting desirable hybrids in sunflower (Helianthus annuus L.). Pak. J. Bot., 44(5): 1715-1720, 2012.

RESENDE, M.D.V. de. Genética biométrica e estatística no melhoramento de plantas perenes. Brasília, DF: Embrapa Informação Tecnológica, 2002. 975p.

RESENDE, M.D.V. de; DUARTE, J.B. Precisão e controle de qualidade em experimentos de avaliação de cultivares. Pesquisa Agropecuária Tropical, v.37, n.3, p.182-194, 2007.

ROHLF, F.J. NTSYS-pc: numerical taxonomy and multivariate analysis system, version 2.1. New York: Exeter Software, 2000. 98p.

SANTOS, M.X. dos. Estudo do potencial de duas raças brasileiras de milho (Zea mays L.) para fins de melhoramento. 1985. 186f. Tese (Doutorado). Universidade de São Paulo. Escola Superior de Agricultura “Luiz de Queiroz”. Piracicaba, SP. 1985.

SANTOS, J.; VENCOVSKY, R. Correlação fenotípica e genética entre alguns caracteres agronômicos do feijoeiro (Phaseolus vulgaris L.). Ciência e Prática, v.10, n.3. p.265-272, 1986.

SAS Institute Inc. 2008. SAS/STAT® 9.2 User’s Guide. Cary, NC: SAS Institute Inc. 2008.

SILVA, J.A.G.; SCHWERTNER, D.V.; KRUGER, C.A.M.B.; CARBONERA, R.; MAIXNER, A.R.; GARCIA, D.C.; CRESTANI, M.; GAVIRAGHI, F.; MARTINS, J.A.K.; MATTER, E. Estimativas de herdabilidade e correlações para caracteres agronômicos em girassol. Revista Brasileira de Agrociência, Pelotas, v.17, n.1-4, p.51-59, 2011.

SINGH, D. The relative importance of characters affecting genetic divergence. The Indian Journal of Genetics e Plant Breeding, v.41, p.237-245, 1981.

SNEATH, P.H.A.; SOKAL, R.R. Numerical taxonomy: the principles and practice of numerical classification. San Francisco: W. H. Freeman, 1973. p.573.

SOKAL, R.R.; ROHLF, F.J. The comparison of dendrograms by objective methods. Taxonomy, v.11, n.1, p.30-40, 1962. 
STATSOFT INC. Statistica for windows [Computer program manual] Tulsa: StatSoft Inc., 1999.

UNGARO, M.R.G. Girassol (Helianthus annuus L.). In: Boletim Informativo do Instituto Agronômico, Campinas, v.200, n.5, p.112-113, 1990.

VENCOVSKY, R. Herança quantitativa. In: PATERNIANI, E.; VIEGAS, G. P. (Eds.). Melhoramento e produção de milho. 2.ed. Campinas: Fundação Cargill, 1987. v.1. 795p. 


\section{CAPÍTULO II}

AVALIAÇÃO DE GENÓTIPOS DE GIRASSOL COM BASE EM CARACTERÍSTICAS MORFOAGRONÔMICAS EM AMBIENTES DO CERRADO BRASILEIRO

SUNFLOWER GENOTYPES EVALUATION BASED ON THE AGRO-MORPHOLOGICAL CHARACTERISTICS IN THE BRAZILIAN SAVANNAH 


\section{AVALIAÇÃO DE GENÓTIPOS DE GIRASSOL COM BASE EM CARACTERÍSTICAS MORFOAGRONÔMICAS EM AMBIENTES DO CERRADO BRASILEIRO}

\subsection{RESUMO}

O presente estudo objetivou a avaliação de dezesseis genótipos de girassol, em três ambientes do Cerrado, com base em características morfoagronômicas, sendo considerados os caracteres rendimento (REND), dias para a floração (DFI) com base na data de florescimento em R5, tamanho do capítulo (TC), peso de mil aquênios (PMA) e altura (ALT). Dois ensaios foram realizados na área experimental da Embrapa - Centro de Pesquisa Agropecuária dos Cerrados, em Planaltina, DF, situada a $15^{\circ} 35^{\prime} 30^{\prime \prime}$ de latitude Sul, $47^{\circ} 42^{\prime} 30^{\prime \prime}$ de longitude Oeste e a altitude de $1.007 \mathrm{~m}$. O outro ensaio foi na área experimental da Embrapa Produtos e Mercado, no Recanto das Emas, DF, a $15^{\circ} 54^{\prime} 53^{\prime \prime}$ de latitude Sul, $48^{\circ} 02^{\prime} 14^{\prime \prime}$ de longitude Oeste e a altitude de $1.254 \mathrm{~m}$. O delineamento experimental utilizado foi de blocos ao acaso com quatro repetições. Houve interação significativa entre os genótipos e os ambientes. Os genótipos HELIO 251, MG 305 e SYN 045 obtiveram os maiores rendimentos. BRS G42, CF 101 e BRS 323 apresentaram menores alturas de planta e ciclo mais precoce.

Palavras-chave: Helianthus annuus L., Distrito Federal, caracteres agromorfológicos. 


\section{SUNFLOWER GENOTYPES EVALUATION BASED ON THE AGRO-MORPHOLOGICAL CHARACTERISTICS IN THE BRAZILIAN SAVANNAH}

\subsection{ABSTRACT}

This study aimed to evaluate sixteen sunflower genotypes in three environments in the Savannah of Central Brazil, based on the following characters: grain yield (REND), days to start flowering (DFI), chapter length (TC), weight of a thousand achenes (PMA) and plant height (ALT). Two trials were conducted at Embrapa Cerrados (Federal District - Brazil) located at $15^{\circ}$ 35' 30" S latitude, $47^{\circ} 42^{\prime} 30^{\prime \prime} \mathrm{W}$ longitude and $1.007 \mathrm{~m}$ above sea level. The other trail was conducted at Embrapa Produtos e Mercado (Federal District - Brazil) located at 15' 54' 53" S latitude, $48^{\circ} 02^{\prime} 14^{\prime \prime} \mathrm{W}$ longitude and $1.254 \mathrm{~m}$ above sea level. A complete randomized block design with four replicates was used. There was a significant interaction between genotypes and between environments. The genotypes HELIO 251, MG 305 and SYN 045 had the best results for grain yield. BRS G42, CF 101 and BRS 323 detained lower values for plant height and days to start flowering.

Key words: Helianthus annuиs L., Federal District, morphological characters. 


\subsection{INTRODUÇÃO}

A alta qualidade do óleo produzido e a adaptabilidade a diferentes condições ambientais colocam o girassol (Helianthus anпииs L.) em destaque. A espécie, quando comparada a outras, demonstra maior resistência à seca e a baixas temperaturas, caracterizando sua condição de potencial para a expansão de área cultivada em diversas regiões do país (CASTRO et al., 2005).

O girassol é uma cultura alternativa ao sistema de produção do Cerrado devido a sua adaptação às condições desse bioma. Para alcançar bons resultados, são necessários estudos que forneçam informações quanto ao desempenho dos genótipos em diferentes locais e épocas de plantio, possibilitando o sucesso de programas de melhoramento. A escolha da cultivar apropriada é um dos fatores decisivos para obter retorno financeiro do investimento em uma lavoura.

No Brasil, tem-se a demanda por genótipos mais adaptados às condições de safrinha, e para isso, buscam-se materiais precoces (OLIVEIRA et al., 2005), com alto teor de óleo, boa produtividade e resistência a condições abióticas e bióticas. Além do rendimento por hectare, avalia-se o peso de mil aquênios, uma vez que este é um fator que afeta a comercialização de sementes de girassol, pois as sacas são usualmente comercializadas pelo peso.

Outra característica desejada é o menor porte das plantas, visto que plantas mais altas possuem maior risco de quebra e acamamento e a altura da lavoura influencia a colheita. $\mathrm{O}$ diâmetro de capítulos também é um atributo avaliado, considerado uma característica quantitativa e morfológica intrínseca do girassol (CASTRO; FARIAS, 2005). Em relação à aferição do ciclo dos materiais, considera-se, por exemplo, o número de dias para o início da floração.

Programas de melhoramento tem por princípio o desenvolvimento de estudos que viabilizem a obtenção de novos materiais, atendendo à demanda constante por genótipos de maior qualidade, que possam amparar o produtor frente a um mercado competitivo. Apesar do grande potencial da espécie, poucos são os trabalhos que avaliam e comparam o desempenho de genótipos de girassol no Cerrado brasileiro.

Neste contexto, o presente trabalho objetiva a avaliação de 16 genótipos de girassol a partir de caracteres morfoagronômicos em sistema de produção no Cerrado do Distrito Federal, 
fornecendo informações importantes que podem ser exploradas pela pesquisa de melhoramento da espécie e podem contribuir para o desenvolvimento de materiais mais apropriados para $\mathrm{o}$ plantio na entressafra do Cerrado brasileiro.

\subsection{MATERIAL E MÉTODOS}

Três ensaios constituíram o presente trabalho, todos no Cerrado do Distrito Federal. Um ensaio (CPAC 01), semeado em 20 de fevereiro de 2014, e um segundo semeado em 25 de março de 2014, realizados na área experimental da Embrapa - Centro de Pesquisa Agropecuária dos

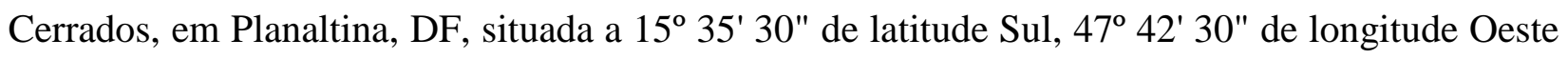
e a altitude de $1.007 \mathrm{~m}$. Um terceiro ensaio (Fazenda Sucupira), de 23 de fevereiro de 2014, foi na área experimental da Embrapa Produtos e Mercado, no Recanto das Emas, DF, a 15 54' 53" de latitude Sul, $48^{\circ} 02^{\prime} 14^{\prime \prime}$ de longitude Oeste e a altitude de $1.254 \mathrm{~m}$. Análises de solo foram realizadas avaliando três camadas: 0 - $10 \mathrm{~cm} ; 10-20 \mathrm{~cm}$; e 20 - $40 \mathrm{~cm}$ (Tabela 1). Os solos foram classificados como LATOSSOLO VERMELHO Distrófico típico, argiloso.

Foram avaliados 16 genótipos (CF 101, ADV 5504, BRS G42, BRS 323, HELIO 250, HELIO 251, SYN 045, SYN 3950HO, MG 305, MG 360, AGUARÁ 04, AGUARÁ 06, PARAÍSO 20, GNZ NEON, HLA 2012 e M734, que foi utilizado como testemunha por ser um material comercial de alta qualidade). O delineamento experimental utilizado foi de blocos ao acaso com quatro repetições. As parcelas continham quatro linhas de 5 metros de comprimento, com espaçamento de $0,8 \mathrm{~m}$ entre linhas. A área útil da parcela foi de $8 \mathrm{~m}^{2}$ e a densidade correspondeu a 33 plantas $/ \mathrm{m}^{2}$. Foram aplicados $400 \mathrm{~kg} \mathrm{ha}^{-1}$ de 4-30-16 como adubação de base e $60 \mathrm{~kg} \mathrm{ha}^{-1}$ de $\mathrm{N}$ como adubação de cobertura nos três ensaios.

Durante o experimento, dados meteorológicos foram coletados na Estação Meteorológica da Embrapa Cerrados. Para o primeiro ensaio, obteve-se temperatura mínima, média e máxima do ar de $8,4{ }^{\circ} \mathrm{C}, 20,74{ }^{\circ} \mathrm{C}$ e $30,8{ }^{\circ} \mathrm{C}$, respectivamente; umidade média do ar de $73,22 \%$; e um somatório de $479,7 \mathrm{~mm}$ de chuva durante todo o período. O outro ensaio, iniciado em 25 de março, obteve temperatura mínima, média e máxima do ar de $8,4{ }^{\circ} \mathrm{C}, 20,24{ }^{\circ} \mathrm{C}$ e $30,8{ }^{\circ} \mathrm{C}$, respectivamente; umidade média do ar de 68,29\%; e um somatório de 181,7 mm de chuva. Para o 
ensaio da Embrapa Produtos e Mercado, usou-se os dados da Estação Meteorológica da Fazenda Água Limpa - FAL/UnB e encontrou-se temperatura mínima, média e máxima do ar de $6,2{ }^{\circ} \mathrm{C}$, $19,3{ }^{\circ} \mathrm{C}$ e $30,5^{\circ} \mathrm{C}$, respectivamente; umidade média do ar de 79,2\%; e um somatório de $637 \mathrm{~mm}$ de chuva durante todo o ensaio.

Através de arado de discos de 32', restos culturais foram incorporados ao solo. Em seguida, utilizou-se uma grade niveladora de 20" para gradagem. Aplicou-se, em pré-emergência o herbicida Trifluralina na dosagem 1,2 L ha-1.

Avaliaram-se os caracteres rendimento (REND) em $\mathrm{kg} \mathrm{ha}^{-1}$, dias para a floração (DFI) com base na data de florescimento em R5, tamanho do capítulo (TC) em $\mathrm{cm}$, peso de mil aquênios (PMA) em g e altura (ALT) em $\mathrm{cm}$. Os dados obtidos foram submetidos à análise de variância através do programa Genes (CRUZ, 1997) e as médias agrupadas através do teste ScottKnott com significância de 1\% (SCOTT; KNOTT, 1974). Em relação ao teste, letras iguais indicam que não há diferença estatística entre os resultados, enquanto letras diferentes indicam diferença estatística entre os dados obtidos. As letras maiúsculas comparam o mesmo genótipo nos diferentes ambientes, enquanto as letras minúsculas comparam os genótipos dentro de um ambiente.

\subsection{RESULTADOS E DISCUSSÃO}

A interação genótipo-ambiente foi significativa, viabilizando a comparação dos desempenhos dos materiais entre os ambientes (Tabela 2). O ensaio Fazenda Sucupira foi o que obteve a maior média de rendimento (4.636,5 $\mathrm{kg} \mathrm{ha}^{-1}$ ), seguido do CPAC $02 \mathrm{com} 4.330,9 \mathrm{~kg} \mathrm{ha}{ }^{-1}$, e do CPAC 01 com 3.174,5 $\mathrm{kg} \mathrm{ha}^{-1}$. Os resultados encontrados neste trabalho apontam o Cerrado como um ambiente favorável ao desenvolvimento do girassol. Os rendimentos encontrados nos três ensaios superam a média nacional $\left(1.560 \mathrm{~kg} \mathrm{ha}^{-1}\right.$ ) observada em 2014 (CONAB, 2015).

Os melhores resultados médios de TC $(19,56 \mathrm{~cm})$ e PMA $(76,72 \mathrm{~g})$ também foram do ensaio Fazenda Sucupira. O ensaio CPAC 01 obteve médias de 16,23 cm e 54,97 g, enquanto CPAC 02 apresentou os valores de 17,78 cm e 65,94 g, para TC e PMA. CPAC 01 foi o ensaio de maior média de altura de planta, com 187,3 cm, seguido do ensaio Fazenda Sucupira e do CPAC 
02, com 174,3 cm e 173,0 cm, nesta ordem. Em relação a DFI, encontrou-se valor médio, em dias, de 55, 50 e 56, para CPAC 01, Fazenda Sucupira e CPAC 02, respectivamente. Capone et al. (2012) também observaram a influência dos ambientes no comportamento das cultivares.

No CPAC 01, o genótipo SYN 045 obteve o maior rendimento $\left(3.786,3 \mathrm{~kg} \mathrm{ha}^{-1}\right)$ sendo estatisticamente semelhante ao genótipo GNZ NEON $\left(3.764,8 \mathrm{~kg} \mathrm{ha}^{-1}\right)$ e diferente estatisticamente da testemunha M734 (3.060,5 $\left.\mathrm{kg} \mathrm{ha}^{-1}\right)$. O material BRS G42 apresentou o menor valor $\left(2.585,3 \mathrm{~kg} \mathrm{ha}^{-1}\right)$, sendo semelhante estatisticamente aos genótipos BRS $323\left(2.783,0 \mathrm{~kg} \mathrm{ha}^{-}\right.$ $\left.{ }^{1}\right)$ e HLA $2012\left(2.723,0 \mathrm{~kg} \mathrm{ha}^{-1}\right)$ e diferente estatisticamente da testemunha.

No ensaio Fazenda Sucupira, AGUARÁ 06 apresentou o rendimento mais alto $(5.105,5$ $\mathrm{kg} \mathrm{ha}^{-1}$ ) e BRS G42 obteve o menor valor (4.057,0 $\left.\mathrm{kg} \mathrm{ha}^{-1}\right)$, sendo os dois materiais estatisticamente distintos da testemunha $\left(4.525,8 \mathrm{~kg} \mathrm{ha}^{-1}\right)$. Os genótipos HELIO 251 (5.036,5 kg $\left.\mathrm{ha}^{-1}\right)$, MG 305 (4.947,5 kg ha $\left.{ }^{-1}\right)$, SYN 3950HO (4.993,5 kg ha-1) e CF $101\left(4.961,8 \mathrm{~kg} \mathrm{ha}^{-1}\right)$ foram estatisticamente semelhantes a AGUARÁ 06, enquanto GNZ NEON (4.087,3 $\left.\mathrm{kg} \mathrm{ha}^{-1}\right)$ foi semelhante estatisticamente a BRS G42.

Já no CPAC 02, MG 305 deteve o melhor rendimento $\left(4.987,3 \mathrm{~kg} \mathrm{ha}^{-1}\right)$ e o genótipo SYN $3950 \mathrm{HO}$ obteve o menor valor $\left(3.880,5 \mathrm{~kg} \mathrm{ha}^{-1}\right)$. Os dois genótipos foram distintos estatisticamente da testemunha $\left(4.249,0 \mathrm{~kg} \mathrm{ha}^{-1}\right)$. HELIO $251\left(4.858,3 \mathrm{~kg} \mathrm{ha} \mathrm{ha}^{-1}\right.$ foi estatisticamente semelhante a MG 305, enquanto ADV 5504 (3.916,3 $\left.\mathrm{kg} \mathrm{ha}^{-1}\right)$, BRS G42 (3.962,8 $\left.\mathrm{kg} \mathrm{ha}^{-1}\right)$, BRS $323\left(4.005,8 \mathrm{~kg} \mathrm{ha}^{-1}\right)$ e GNZ NEON (3.924,3 $\mathrm{kg} \mathrm{ha}^{-1}$ ) foram semelhantes estatisticamente a SYN 3950HO. Nota-se que os menores valores encontrados para rendimento, nos ensaios Fazenda Sucupira e CPAC 02 superaram o maior valor encontrado no CPAC 01.

Em relação a DFI, os programas de melhoramento buscam genótipos com menor ciclo. Dessa forma, é possível conciliar o plantio de girassol em safrinha e reduzir a probabilidade de que ocorra estresse hídrico durante o florescimento. Nos ensaios CPAC 01 e CPAC 02, os genótipos CF 101, ADV 5504 e BRS G42 foram semelhantes estatisticamente entre si e apresentaram-se como os materiais mais precoces. No ensaio Fazenda Sucupira, SYN 045, AGUARÁ 06, MG 360 e BRS 323 foram os mais precoces e assemelharam-se estatisticamente entre si. O genótipo GNZ NEON foi o de maior valor para DFI, apresentando 73 e 74 dias nos ensaios CPAC 01 e CPAC 02, respectivamente. Em contrapartida, este material apresentou 44 
dias para DFI no ensaio Fazenda Sucupira, no qual MG 305 foi o de maior valor (70 dias). A testemunha M734 foi estatisticamente diferente dos valores máximos e mínimos encontrados em todos os ambientes, apresentando 63, 60 e 64 dias no CPAC 01, Fazenda Sucupira e CPAC 02, respectivamente.

A variável TC não obteve diferença estatística no CPAC 01. Os valores máximo, médio e mínimo foram 17,75 cm (PARAISO 20), 16,23 cm e 14,75 cm (BRS 323 e AGUARÁ 06). A testemunha M734 apresentou 15,75 cm. No ensaio Fazenda Sucupira, SYN 045 obteve o maior valor $(22,50 \mathrm{~cm})$, sendo estatisticamente semelhante à testemunha $(20,50 \mathrm{~cm})$ e aos genótipos PARAISO 20, AGUARÁ 06, HELIO 251, MG 305, HLA 2012, SYN 3950HO e MG 360. No CPAC 02, o genótipo de maior TC foi MG $305(21,00 \mathrm{~cm})$, semelhante estatisticamente de PARAISO 20, SYN 045, HELIO 251 e HELIO 250.

Para PMA, no CPAC 01, BRS G42 (69,25 g), a testemunha M734 (68,75 g) e SYN 045 $(68,00 \mathrm{~g})$ detiveram os maiores valores, assemelhando-se estatisticamente. Por outro lado, CF 101 (44,00 g), MG 305 (45,50 g), AGUARÁ 04 (47,00 g) e PARAISO 20 (42,50 g) foram os genótipos com menor PMA, estatisticamente semelhantes entre si, porém diferentes em relação à testemunha. No ensaio Fazenda Sucupira, HELIO 251 (88,00 g), GNZ NEON (85,50 g) e MG $360(85,25 \mathrm{~g})$ apresentaram os melhores resultados, sendo semelhantes estatisticamente à testemunha (84,50 g). Os menores valores foram dos genótipos ADV 5504 (63,75 g), HELIO 250 (65,75 g), AGUARÁ 06 (70,25 g) e PARAISO 20 (70,00 g). No CPAC 02, os materiais GNZ NEON (81,50 g), HLA 2012 (81,00 g) e SYN 045 (77,75 g) foram estatisticamente semelhantes e obtiveram os maiores resultados. Os genótipos PARAISO 20 (53,50 g), AGUARÁ 06 (57,25 g), HELIO 251 (59,25 g), ADV 5504 (58,25 g) e CF 101 (54,25 g) assemelharam-se estatisticamente e apresentaram os valores menores. A testemunha M734 deteve um valor intermediário (71,75 g), sendo diferente estatisticamente dos genótipos de maiores e dos de menores resultados.

Quanto à altura, no CPAC 01, os genótipos com plantas mais altas foram GNZ NEON $(215,0 \mathrm{~cm})$, PARAISO $20(207,5 \mathrm{~cm})$ e SYN $045(202,5 \mathrm{~cm})$, semelhantes estatisticamente entre si. Em contrapartida, ADV $5504(162,5 \mathrm{~cm})$, CF $101(166,8 \mathrm{~cm})$ e BRS G42 (165,0 cm) apresentaram as menores alturas, assemelhando-se estatisticamente. Plantas muito altas não são desejadas, uma vez que podem sofrer quebra ou acamamento e podem dificultar a colheita. A 
testemunha obteve média de $187,5 \mathrm{~cm}$, sendo estatisticamente diferente dos menores e dos maiores materiais. No ensaio Fazenda Sucupira, GNZ NEON (198,8 cm), a testemunha M734 (195,0 cm), HELIO $251(195,0 \mathrm{~cm})$, AGUARÁ $06(196,3 \mathrm{~cm})$ e PARAISO $20(191,3 \mathrm{~cm})$ foram semelhantes estatisticamente e apresentaram as maiores alturas. BRS $323(126,3 \mathrm{~cm})$, BRS G42 $(132,5 \mathrm{~cm})$ e HELIO $250(129,5 \mathrm{~cm})$ detiveram os menores valores, estatisticamente semelhantes entre si. No CPAC 02, MG 305 foi estatisticamente diferente dos demais, apresentando a maior altura $(211,3 \mathrm{~cm})$. A testemunha obteve um valor intermediário $(167,0 \mathrm{~cm})$ e foi diferente estatisticamente dos materiais com menores valores: BRS $323(149,5 \mathrm{~cm}), \mathrm{CF} 101(156,5 \mathrm{~cm})$, BRS G42 (156,8 cm) e AGUARÁ $04(160,0 \mathrm{~cm})$.

\subsection{CONCLUSÕES}

Houve interação significativa entre os genótipos e os ambientes. O ensaio Fazenda Sucupira deteve as maiores médias de rendimento, tamanho de capítulo e peso de mil aquênios. Este ensaio também obteve menores valores de dias para floração e altura.

De modo geral, os genótipos HELIO 251, MG 305 e SYN 045 destacaram-se pelo alto rendimento. BRS G42, CF 101 e BRS 323 apresentaram menores alturas de planta e ciclo mais precoce. 


\subsection{TABELAS E FIGURAS}

Tabela 1. Resultados das análises do solo das camadas $0-10 \mathrm{~cm}, 10-20 \mathrm{~cm}$ e $20-40 \mathrm{~cm}$. Embrapa Cerrados, Planaltina, DF, 2014. Embrapa Produtos e Mercado, Recanto das Emas, DF, 2014.

\begin{tabular}{cccccccccc}
\hline Amostras & $\begin{array}{c}\mathrm{Al}- \\
\text { trocável } \\
\left(\mathrm{mmol}_{\mathrm{c}} \mathrm{dm}^{-3}\right)\end{array}$ & $\begin{array}{c}\mathrm{Ca} \\
\left(\mathrm{mmol}_{\mathrm{c}} \mathrm{dm}^{-3}\right)\end{array}$ & $\begin{array}{c}\mathrm{H}+\mathrm{Al} \\
\left(\mathrm{mmol}_{\mathrm{c}} \mathrm{dm}^{-3}\right)\end{array}$ & $\begin{array}{c}\mathrm{K} \\
\left(\mathrm{mmol}_{\mathrm{c}} \mathrm{dm}^{-3}\right)\end{array}$ & $\begin{array}{c}\text { Matéria } \\
\text { Orgânica } \\
\left(\mathrm{g} \mathrm{dm}^{-3}\right)\end{array}$ & $\begin{array}{c}\mathrm{Mg} \\
\left(\mathrm{mmol}_{\mathrm{c}} \mathrm{dm}^{-3}\right)\end{array}$ & $\begin{array}{c}\mathrm{pH} \\
\mathrm{em} \\
\text { água }^{2}\end{array}$ & $\begin{array}{c}\mathrm{pH} \\
\mathrm{em} \\
\mathrm{CaCl}_{2}\end{array}$ & $\begin{array}{c}\mathrm{P} \\
\left(\mathrm{mg} \mathrm{dm}^{-3}\right)\end{array}$ \\
\hline $0-10 \mathrm{~cm}^{1}$ & 1,18 & 23,7 & 59,28 & 7,7 & 33,87 & 7,8 & 5,76 & 4,93 & 39,87 \\
$10-20 \mathrm{~cm}^{1}$ & 1,50 & 22,1 & 61,31 & 5,6 & 31,83 & 6,0 & 5,56 & 4,81 & 40,95 \\
$20-40 \mathrm{~cm}^{1}$ & 0,24 & 21,5 & 36,34 & 3,9 & 26,45 & 6,2 & 5,88 & 5,30 & 6,23 \\
$0-10 \mathrm{~cm}^{2}$ & 0,02 & 43,5 & 35,53 & 0,7 & 42,23 & 19,2 & 6,51 & 6,18 & 36,76 \\
$10-20 \mathrm{~cm}^{2}$ & 0,50 & 20,7 & 65,77 & 0,8 & 36,27 & 11,3 & 5,55 & 5,17 & 79,07 \\
$20-40 \mathrm{~cm}^{2}$ & 1,04 & 7,9 & 46,28 & 1,2 & 29,80 & 3,9 & 5,14 & 4,79 & 2,22 \\
$0-10 \mathrm{~cm}^{3}$ & 0,02 & 34,1 & 41,41 & 3,5 & 33,49 & 11,7 & 6,15 & 5,43 & 8,52 \\
$10-20 \mathrm{~cm}^{3}$ & 0,06 & 29,8 & 34,51 & 1,3 & 29,99 & 10,5 & 6,16 & 5,51 & 6,88 \\
$20-40 \mathrm{~cm}^{3}$ & 0,36 & 14,35 & 35,73 & 0,8 & 23,71 & 7,25 & 5,88 & 5,24 & 1,40 \\
\hline
\end{tabular}

'Embrapa Cerrados, Planaltina, DF, 2014 (CPAC 01).

${ }^{2}$ Embrapa Produtos e Mercado, Recando das Emas, DF, 2014 (Fazenda Sucupira).

${ }^{3}$ Embrapa Cerrados, Planaltina, DF, 2014 (CPAC 02). 
Tabela 2. Valores médios de rendimento de grãos (REND), dias para floração (DFI), tamanho do capitulo (TC), peso de mil aquênios (PMA), e altura (ALT) nos ambientes CPAC 01, Fazenda Sucupira e CPAC 02, submetidos ao teste de Scott-Knott a 1\%, no Distrito Federal, Brasil, 2014.

\begin{tabular}{|c|c|c|c|c|c|c|c|c|c|c|c|c|c|c|c|}
\hline \multirow[b]{2}{*}{ Genótipo } & \multicolumn{3}{|c|}{ Rendimento (kg ha ${ }^{-1}$ ) } & \multicolumn{3}{|c|}{ Dias para floração } & \multicolumn{3}{|c|}{ Tamanho do capítulo (cm) } & \multicolumn{3}{|c|}{ Peso de mil aquênios (g) } & \multicolumn{3}{|c|}{ Altura (cm) } \\
\hline & $\begin{array}{c}\text { CPAC } \\
01\end{array}$ & $\begin{array}{l}\text { Fazenda } \\
\text { Sucupira }\end{array}$ & $\begin{array}{c}\text { CPAC } \\
02\end{array}$ & $\begin{array}{c}\text { CPAC } \\
01\end{array}$ & \begin{tabular}{|l|} 
Fazenda \\
Sucupira
\end{tabular} & $\begin{array}{c}\text { CPAC } \\
02\end{array}$ & $\begin{array}{c}\text { CPAC } \\
01\end{array}$ & $\begin{array}{l}\text { Fazenda } \\
\text { Sucupira }\end{array}$ & $\begin{array}{c}\text { CPAC } \\
02\end{array}$ & $\begin{array}{c}\text { CPAC } \\
01\end{array}$ & $\begin{array}{l}\text { Fazenda } \\
\text { Sucupira }\end{array}$ & $\begin{array}{c}\text { CPAC } \\
02\end{array}$ & $\begin{array}{c}\text { CPAC } \\
01\end{array}$ & $\begin{array}{l}\text { Fazenda } \\
\text { Sucupira }\end{array}$ & $\begin{array}{c}\text { CPAC } \\
02\end{array}$ \\
\hline CF 101 & $3154,8 \mathrm{Cc}$ & $4961,8 \mathrm{Aa}$ & $4249,3 \mathrm{Bc}$ & $38 \mathrm{Bi}$ & $48 \mathrm{Ae}$ & $39 \mathrm{Bi}$ & $15,75 \mathrm{Ba}$ & $18,50 \mathrm{Ab}$ & $16,00 \mathrm{Bb}$ & $44,00 \mathrm{Cd}$ & $79,50 \mathrm{Ab}$ & $54,25 \mathrm{Bd}$ & $166,8 \mathrm{Ad}$ & $168,8 \mathrm{Ac}$ & $156,5 \mathrm{Be}$ \\
\hline ADV 5504 & $3440,0 \mathrm{Cb}$ & $4545,8 \mathrm{Ac}$ & $3916,3 \mathrm{Bd}$ & $38 \mathrm{Bi}$ & $45 \mathrm{Ag}$ & $39 \mathrm{Bi}$ & $15,50 \mathrm{Ba}$ & $18,50 \mathrm{Ab}$ & $16,25 \mathrm{Bb}$ & $50,75 \mathrm{Bc}$ & $63,75 \mathrm{Ad}$ & $58,25 \mathrm{Ad}$ & $162,5 \mathrm{Ad}$ & $175,0 \mathrm{Ac}$ & $166,5 \mathrm{Ad}$ \\
\hline BRS G42 & $2585,3 \mathrm{Be}$ & $4057,0 \mathrm{Ae}$ & $3962,8 \mathrm{Ad}$ & $39 \mathrm{Bi}$ & $48 \mathrm{Ae}$ & $39 \mathrm{Bi}$ & $16,75 \mathrm{Aa}$ & $18,25 \mathrm{Ab}$ & $17,50 \mathrm{Ab}$ & $69,25 \mathrm{Ba}$ & $76,50 \mathrm{Ac}$ & $68,25 \mathrm{Bb}$ & $165,0 \mathrm{Ad}$ & $132,5 \mathrm{Be}$ & $156,8 \mathrm{Ae}$ \\
\hline M734 (T) & $3060,5 \mathrm{Cc}$ & $4525,8 \mathrm{Ac}$ & $4249,0 \mathrm{Bc}$ & $63 \mathrm{Bc}$ & $60 \mathrm{Cc}$ & $64 \mathrm{Ac}$ & $15,75 \mathrm{Ba}$ & $20,50 \mathrm{Aa}$ & $18,00 \mathrm{Bb}$ & $68,75 \mathrm{Ba}$ & $84,50 \mathrm{Aa}$ & $71,75 \mathrm{Bb}$ & $187,5 \mathrm{Ab}$ & 195,0 Aa & $167,0 \mathrm{Bd}$ \\
\hline HELIO 250 & $3379,3 \mathrm{Bb}$ & $4390,0 \mathrm{Ac}$ & $4250,5 \mathrm{Ac}$ & $47 \mathrm{Bg}$ & $55 \mathrm{Ad}$ & $48 \mathrm{Bg}$ & $16,00 \mathrm{Aa}$ & $18,00 \mathrm{Ab}$ & $19,00 \mathrm{Aa}$ & $51,50 \mathrm{Bc}$ & $65,75 \mathrm{Ad}$ & $61,50 \mathrm{Ac}$ & $183,8 \mathrm{Ac}$ & $129,5 \mathrm{Ce}$ & $168,8 \mathrm{Bd}$ \\
\hline SYN 3950HO & $3429,0 \mathrm{Cb}$ & 4993,5 Aa & $3880,5 \mathrm{Bd}$ & $63 \mathrm{Ac}$ & $55 \mathrm{Bd}$ & $64 \mathrm{Ac}$ & $16,75 \mathrm{Ba}$ & $20,50 \mathrm{Aa}$ & $17,00 \mathrm{Bb}$ & $59,00 \mathrm{Bb}$ & $76,25 \mathrm{Ac}$ & $61,50 \mathrm{Bc}$ & $188,8 \mathrm{Ab}$ & $160,0 \mathrm{Cd}$ & $174,0 \mathrm{Bd}$ \\
\hline BRS 323 & $2783,0 \mathrm{Ce}$ & $4532,8 \mathrm{Ac}$ & $4005,8 \mathrm{Bd}$ & $43 \mathrm{Ah}$ & $40 \mathrm{Bi}$ & $44 \mathrm{Ah}$ & $14,75 \mathrm{Ba}$ & $17,25 \mathrm{Ab}$ & $17,50 \mathrm{Ab}$ & $61,75 \mathrm{Bb}$ & $81,00 \mathrm{Ab}$ & $65,00 \mathrm{Bc}$ & $177,5 \mathrm{Ac}$ & $126,3 \mathrm{Ce}$ & $149,5 \mathrm{Be}$ \\
\hline MG 360 & $2884,3 \mathrm{Cd}$ & $4787,5 \mathrm{Ab}$ & $4350,0 \mathrm{Bc}$ & $48 \mathrm{Ag}$ & $40 \mathrm{Bi}$ & $49 \mathrm{Ag}$ & $15,75 \mathrm{Ba}$ & $21,25 \mathrm{Aa}$ & $16,25 \mathrm{Bb}$ & $58,00 \mathrm{Cb}$ & $85,25 \mathrm{Aa}$ & $72,25 \mathrm{Bb}$ & $173,8 \mathrm{Bc}$ & $187,5 \mathrm{Ab}$ & $166,5 \mathrm{Bd}$ \\
\hline GNZ NEON & $3764,8 \mathrm{Ba}$ & $4087,3 \mathrm{Ae}$ & $3924,3 \mathrm{Bd}$ & $73 \mathrm{Aa}$ & $44 \mathrm{Bg}$ & $74 \mathrm{Aa}$ & $17,50 \mathrm{Aa}$ & $19,00 \mathrm{Ab}$ & $17,25 \mathrm{Ab}$ & $62,75 \mathrm{Bb}$ & $85,50 \mathrm{Aa}$ & $81,50 \mathrm{Aa}$ & $215,0 \mathrm{Aa}$ & $198,8 \mathrm{Ba}$ & $197,3 \mathrm{Bb}$ \\
\hline HLA 2012 & $2723,0 \mathrm{Ce}$ & $4474,0 \mathrm{Bc}$ & $4730,5 \mathrm{Ab}$ & $68 \mathrm{Ab}$ & $65 \mathrm{Bb}$ & $69 \mathrm{Ab}$ & $16,75 \mathrm{Ba}$ & $20,25 \mathrm{Aa}$ & $17,50 \mathrm{Bb}$ & $51,75 \mathrm{Bc}$ & $78,75 \mathrm{Ab}$ & $81,00 \mathrm{Aa}$ & $190,0 \mathrm{Ab}$ & $182,5 \mathrm{Ab}$ & $179,8 \mathrm{Ac}$ \\
\hline MG 305 & $3493,3 \mathrm{Bb}$ & 4947,5 Aa & 4987,3 Aa & $61 \mathrm{Bd}$ & $70 \mathrm{Aa}$ & $62 \mathrm{Bd}$ & $16,50 \mathrm{Ba}$ & $20,50 \mathrm{Aa}$ & $21,00 \mathrm{Aa}$ & $45,50 \mathrm{Bd}$ & $75,75 \mathrm{Ac}$ & $69,00 \mathrm{Ab}$ & $198,8 \mathrm{Bb}$ & $187,5 \mathrm{Bb}$ & $211,3 \mathrm{Aa}$ \\
\hline HELIO 251 & $3041,3 \mathrm{Bc}$ & $5036,5 \mathrm{Aa}$ & $4858,3 \mathrm{Aa}$ & $57 \mathrm{Ae}$ & $46 \mathrm{Bf}$ & $59 \mathrm{Ae}$ & $15,50 \mathrm{Ba}$ & $20,00 \mathrm{Aa}$ & $19,75 \mathrm{Aa}$ & $48,50 \mathrm{Cc}$ & $88,00 \mathrm{Aa}$ & $59,25 \mathrm{Bd}$ & $198,8 \mathrm{Ab}$ & $195,0 \mathrm{Aa}$ & $176,8 \mathrm{Bd}$ \\
\hline AGUARÁ 06 & $2946,5 \mathrm{Cd}$ & $5105,5 \mathrm{Aa}$ & $4287,3 \mathrm{Bc}$ & $63 \mathrm{Ac}$ & $40 \mathrm{Bi}$ & $64 \mathrm{Ac}$ & $14,75 \mathrm{Ba}$ & $19,50 \mathrm{Aa}$ & $17,25 \mathrm{Ab}$ & $50,50 \mathrm{Bc}$ & $70,25 \mathrm{Ad}$ & $57,25 \mathrm{Bd}$ & $195,0 \mathrm{Ab}$ & 196,3 Аа & $166,3 \mathrm{Bd}$ \\
\hline AGUARÁ 04 & $2896,5 \mathrm{Cd}$ & $4283,0 \mathrm{Bd}$ & $4742,0 \mathrm{Ab}$ & $51 \mathrm{Af}$ & $43 \mathrm{Bh}$ & $52 \mathrm{Af}$ & $17,25 \mathrm{Aa}$ & $18,25 \mathrm{Ab}$ & $17,25 \mathrm{Ab}$ & $47,00 \mathrm{Cd}$ & $73,50 \mathrm{Ac}$ & $63,00 \mathrm{Bc}$ & $183,8 \mathrm{Ac}$ & $186,3 \mathrm{Ab}$ & $160,0 \mathrm{Be}$ \\
\hline PARAISO 20 & $3423,8 \mathrm{Cb}$ & $4621,3 \mathrm{Ac}$ & $4356,8 \mathrm{Bc}$ & $62 \mathrm{Bd}$ & $60 \mathrm{Cc}$ & $64 \mathrm{Ac}$ & $17,75 \mathrm{Aa}$ & $20,25 \mathrm{Aa}$ & $18,50 \mathrm{Aa}$ & $42,50 \mathrm{Cd}$ & $70,00 \mathrm{Ad}$ & $53,50 \mathrm{Bd}$ & $207,5 \mathrm{Aa}$ & $191,3 \mathrm{Ba}$ & $190,0 \mathrm{Bc}$ \\
\hline SYN 045 & $3786,3 \mathrm{Ca}$ & $4834,5 \mathrm{Ab}$ & $4544,5 \mathrm{Bb}$ & $68 \mathrm{Ab}$ & $40 \mathrm{Bi}$ & $69 \mathrm{Ab}$ & $16,75 \mathrm{Ba}$ & $22,50 \mathrm{Aa}$ & $18,50 \mathrm{Ba}$ & $68,00 \mathrm{Ba}$ & $73,25 \mathrm{Ac}$ & 77,75 Aa & $202,5 \mathrm{Aa}$ & $176,3 \mathrm{Bc}$ & $181,3 \mathrm{Bc}$ \\
\hline Mínimo & 2585,3 & 4057,0 & 3880,5 & 38 & 40 & 39 & 14,75 & 17,25 & 16,00 & 42,50 & 63,75 & 53,50 & 162,5 & 126,3 & 149,5 \\
\hline Média & 3174,5 & 4636,5 & 4330,9 & 55 & 50 & 56 & 16,23 & 19,56 & 17,78 & 54,97 & 76,72 & 65,94 & 187,3 & 174,3 & 173,0 \\
\hline Máximo & 3786,3 & 5105,5 & 4987,3 & 73 & 70 & 74 & 17,75 & 22,50 & 21,00 & 69,25 & 88,00 & 81,50 & 215,0 & 198,8 & 211,3 \\
\hline Desvio Padrão & 366,30 & 331,97 & 354,72 & 11,69 & 9,69 & 11,84 & 0,91 & 1,39 & 1,33 & 9,04 & 7,15 & 9,01 & 15,44 & 24,61 & 16,15 \\
\hline Variância & 134175,49 & 110203,19 & 125826,30 & 136,65 & 93,93 & 140,16 & 0,82 & 1,94 & 1,76 & 81,77 & 51,13 & 81,10 & 238,34 & 605,67 & 260,70 \\
\hline QM & $536676,81 * *$ & 440812,76 & 503305,19 & 546,92 & 374,35 & 559,33 & 3,28 & 7,75 & 7,03 & 327,10 & 204,53 & 324,38 & 953,81 & 2422,68 & 1042,80 \\
\hline Teste F & $61,41 * *$ & $57,08^{* *}$ & $23,48^{* *}$ & $1147,23^{* * *}$ & $1240,65^{* *}$ & $826,93^{* *}$ & $1,82^{\mathrm{Ns}}$ & $4,35 * *$ & $2,25^{*}$ & $18,36^{* *}$ & $13,15^{* *}$ & $28,48 * *$ & $13,16^{* *}$ & $123,53^{* *}$ & $36,19^{* *}$ \\
\hline$h_{a}^{2}$ & 98,37 & 98,25 & 95,74 & 99,91 & 99,92 & 99,88 & 45,11 & 77,03 & 55,60 & 94,55 & 92,40 & 96,49 & 92,40 & 99,19 & 97,24 \\
\hline $\mathrm{CV}$ & 2,95 & 1,90 & 3,38 & 1,25 & 1,10 & 1,47 & 8,27 & 6,82 & 9,94 & 7,68 & 5,14 & 5,12 & 4,55 & 2,54 & 3,10 \\
\hline
\end{tabular}

Letras maiúsculas comparam o mesmo genótipo nos diferentes ambientes. Letras minúsculas comparam os genótipos dentro do mesmo ambiente. Letras iguais indicam que não há diferença estatística entre os resultados, enquanto letras diferentes indicam diferença estatística (Teste Scott-Knott a 1\%). 


\subsection{REFERÊNCIAS BIBLIOGRÁFICAS}

CAPONE, A.; BARROS, H. B.; SANTOS, E. R. dos.; FERRAZ, E. C.; SANTOS, A. F. dos.; FIDÉLIS, R. R. Épocas de semeadura de girassol 'safrinha', em sucessão a girassol no cerrado tocantinense. Journal of Biotechnology and Biodiversity, Cidade, v. 3, n. 2, p. 72-79, 2012.

CASTRO, C. de; FARIAS, J.R.B. Ecofisiologia do girassol. In: LEITE, R.M.V.B.C.; BRIGHENTI, A.M.; CASTRO, C. de. Girassol no Brasil. Londrina: Embrapa, CNPSo, 2005. p.163-218.

CONAB. Companhia Nacional de Abastecimento. Acompanhamento da Safra Brasileira.

Disponível em:

<http://www.conab.gov.br/OlalaCMS/uploads/arquivos/14_09_10_14_35_09_boletim_graos_set embro_2014.pdf>. Acesso em 17 fev. 2016.

CRUZ, C. D. Programa Genes: aplicativo computacional em genética e estatística. Versão Windows - 2007. Viçosa, MG: editora UFV, 1997. v. 1. 442 p.

OLIVEIRA, M. F. et al. Melhoramento do girassol. In: LEITE, R. M. V. B. C. Manejo de doenças do girassol. In: LEITE, R. M. V. B. C. et al. Girassol no Brasil. Londrina: Embrapa Soja, 2005. p. 269-297.

SCOTT, A.J \& KNOTT, M. Accouter analysis methods for grouping means in the analysis of variants. Biometrics, 30: p. 507-512, 1974. 


\section{CAPítULO III}

AVALIAÇÃO DA SEVERIDADE DA MANCHA-DE-ALTERNÁRIA EM GIRASSOL NO CERRADO DO DISTRITO FEDERAL

SEVERITY EVALUATION OF ALTERNARIA ON SUNFLOWER IN THE BRAZILIAN SAVANNAH OF THE FEDERAL DISTRICT 


\section{AVALIAÇÃO DA SEVERIDADE DA MANCHA-DE-ALTERNÁRIA EM GIRASSOL NO CERRADO DO DISTRITO FEDERAL}

\subsection{RESUMO}

Este trabalho tem por finalidade avaliar a severidade da Mancha-de-alternária, doença causada pelo fungo Alternaria helianthi (Hansf.) Tubaki e Nishihara, em dezesseis genótipos de girassol, em três ambientes do Cerrado do Distrito Federal. Dois ensaios foram realizados na área experimental da Embrapa - Centro de Pesquisa Agropecuária dos Cerrados, em Planaltina, DF, situada a $15^{\circ} 35^{\prime} 30^{\prime \prime}$ de latitude Sul, $47^{\circ} 42^{\prime} 30^{\prime \prime}$ de longitude Oeste e a altitude de $1.007 \mathrm{~m}$. O outro ensaio foi na área experimental da Embrapa Produtos e Mercado, no Recanto das Emas, $\mathrm{DF}$, a $15^{\circ} 54^{\prime} 53^{\prime \prime}$ de latitude Sul, $48^{\circ} 02^{\prime} 14^{\prime \prime}$ de longitude Oeste e a altitude de $1.254 \mathrm{~m}$. O delineamento experimental utilizado foi de blocos ao acaso. Cinco avaliações, referentes aos sintomas da presença de alternária, foram realizadas a partir dos 35 dias após emergência com intervalos de quinze dias. Foram avaliados os terços inferiores, médios e superiores de cada planta considerada. Os dados obtidos permitiram o cálculo da variável área abaixo da curva de progresso da doença (AACPD). A interação genótipo-ambiente foi significativa. Houve maior presença de sintomas no terço inferior das plantas. Os genótipos CF 101, ADV 5504, BRS G42, HELIO 250, SYN 3950HO, BRS 323, HELIO 251, AGUARÁ 06 e AGUARÁ 04 expressaram menores valores de AACPD no terço inferior, sendo estatisticamente diferentes da testemunha M734. Os valores de AACPD encontrados foram baixos, indicando pouca doença. As condições ambientais não favoreceram a Mancha-de-alternária.

Palavras-chave: Helianthus annuus L., Alternaria helianthi, doença foliar, resistência. 
SEVERITY EVALUATION OF ALTERNARIA ON SUNFLOWER IN THE BRAZILIAN SAVANNAH OF THE FEDERAL DISTRICT

\subsection{ABSTRACT}

This study aims to evaluate the severity of alternaria leaf spot, a disease caused by the fungus Alternaria helianthi (Hansf.) Tubaki and Nishihara, on sixteen sunflower genotypes, in three different environments of the Brazilian Savannah. Two trials were conducted at Embrapa Cerrados (Federal District - Brazil) located at $15^{\circ} 35^{\prime} 30^{\prime \prime} \mathrm{S}$ latitude, $47^{\circ} 42^{\prime} 30^{\prime \prime} \mathrm{W}$ longitude and $1.007 \mathrm{~m}$ above sea level, and the other one at Embrapa Produtos e Mercado (Federal District Brazil), located at $15^{\circ} 54^{\prime} 53^{\prime \prime} \mathrm{S}$ latitude, $48^{\circ} 02^{\prime} 14^{\prime \prime} \mathrm{W}$ longitude and $1.254 \mathrm{~m}$ above sea level. A complete randomized block design was used. Five evaluations were conducted at intervals of fifteen days. The lower part, the middle and the top of each plant were considered. The data allowed the calculation of the variable area under the disease progress curve (AUDPC). Genotype-environment interaction was significant. There were more symptoms in the lower third of the plants. The genotypes CF 101, ADV 5504, BRS G42, HELIO 250, SYN 3950HO, BRS 323, HELIO 251, AGUARÁ 06 and AGUARÁ 04 expressed lower AUDPC values in the lower third, being statistically different from M734. The AUDPC values were low, indicating little disease. Environmental conditions did not favor alternaria leaf spot.

Key words: Helianthus annuus L., Alternaria helianthi, leaf disease, resistance. 


\subsection{INTRODUÇÃO}

O girassol (Helianthus annuus L.) é caracterizado como uma espécie fornecedora de óleo de grande qualidade, detendo alto potencial de exploração por apresentar adaptabilidade a diferentes condições ambientais. Um dos grandes desafios da produção de girassol, bem como da maioria das espécies, é o ataque de patógenos. Zimmer e Hoes (1978) destacam a ocorrência de doenças como elemento que mais influencia a produtividade do girassol.

A Mancha-de-alternária, causada pelo fungo Alternaria helianthi (Hansf.) Tubaki e Nishihara, afeta folhas, hastes e capítulo (CASTRO, 1996) podendo comprometer a produção da espécie, causando senescência das folhas e até morte da planta. A doença é caracterizada pela presença de sintomas como pontos necróticos com halo amarelecido, que podem acometer o desenvolvimento da planta através da diminuição da superfície fotossintética. As folhas baixeiras sofrem os primeiros sintomas e conforme a doença avança a parte superior também é afetada.

Para o manejo eficiente da alternariose, faz-se necessário o uso de medidas que atenuem ou evitem perdas, como práticas de rotação de cultura ou uso de sementes sadias, que podem contribuir para o crescimento saudável do girassol. O controle químico também pode ser utilizado, de forma preventiva e/ou curativa, contribuindo para obtenção de lavouras mais limpas. Existem fungicidas no mercado registrados para a cultura do girassol, o que viabiliza este tipo de controle por parte do produtor.

A adequação dos locais e épocas de plantio, bem como o conhecimento do histórico das áreas caracterizam medidas de evasão importantes para propiciar um desenvolvimento sadio das plantas. Temperatura e a umidade relativa do ar são elementos meteorológicos de alta relevância que afetam a relação patógeno-planta (LEITE; AMORIM, 2002). A variação de altitude e latitude também pode acarretar variações térmicas. Deve-se atentar também para as formas de dispersão dos fungos e para os fatores que podem auxiliar a disseminação. Em decorrência de precipitação, por exemplo, ocorre a presença de água livre, o que pode propiciar o estabelecimento dos esporos dos fungos mediante entrada pelos estômatos.

Outro fator importante para o manejo fitossanitário é a escolha de genótipos menos susceptíveis à Mancha-de-alternária. A resistência genética pode ser considerada como a maneira 
mais econômica de se conter os danos causados pela doença (DAVET et al., 1991). Após introduzida no campo de produção, o controle da Mancha-de-alternária é difícil, e por isso faz-se necessário o uso de estratégias de manejo. A busca por materiais adaptados às condições de cultivo e a avaliação da resistência a doenças são fundamentais para o sucesso de programas de melhoramento de girassol.

\subsection{MATERIAL E MÉTODOS}

O trabalho constituiu em três ensaios, todos no Cerrado do Distrito Federal, dois na área experimental da Embrapa - Centro de Pesquisa Agropecuária dos Cerrados, em Planaltina, DF, situada a $15^{\circ} 35^{\prime} 30^{\prime \prime}$ de latitude Sul, 47 42' 30" de longitude Oeste e a altitude de $1.007 \mathrm{~m}$ e um na área experimental da Embrapa Produtos e Mercado, no Recanto das Emas, DF, a 15 54' 53" de latitude Sul, $48^{\circ} 02^{\prime} 14^{\prime \prime}$ de longitude Oeste e a altitude de $1.254 \mathrm{~m}$. Os solos foram classificados como LATOSSOLO VERMELHO Distrófico típico, argiloso.

O primeiro ensaio da Embrapa Cerrados (CPAC 01) e o da Embrapa Produtos e Mercado (Fazenda Sucupira) foram semeados em fevereiro de 2014, nos dias 20 e 23, respectivamente. O segundo ensaio na Embrapa Cerrados (CPAC 02) foi iniciado no dia 25 de março de 2014.

Durante o experimento, dados meteorológicos foram coletados na Estação Meteorológica da Embrapa Cerrados. Para o ensaio CPAC 01, obteve-se temperatura mínima, média e máxima do ar de $8,4^{\circ} \mathrm{C}, 20,74^{\circ} \mathrm{C}$ e $30,8^{\circ} \mathrm{C}$, respectivamente; umidade média do ar de $73,22 \%$; e um somatório de 479,7 mm de chuva durante todo o período. Para CPAC 02, iniciado em 25 de março, obteve temperatura mínima, média e máxima do ar de $8,4^{\circ} \mathrm{C}, 20,24^{\circ} \mathrm{C}$ e $30,8^{\circ} \mathrm{C}$, respectivamente; umidade média do ar de 68,29\%; e um somatório de 181,7 mm de chuva. Para o ensaio Fazenda Sucupira, usaram-se os dados da Estação Meteorológica da Fazenda Água Limpa - FAL/UnB e encontrou-se temperatura mínima, média e máxima do ar de $6,2^{\circ} \mathrm{C}, 19,3^{\circ} \mathrm{C}$ e $30,5^{\circ} \mathrm{C}$, respectivamente; umidade média do ar de 79,2\%; e um somatório de $637 \mathrm{~mm}$ de chuva durante todo o ensaio.

Foram avaliados 16 genótipos (CF 101, ADV 5504, BRS G42, BRS 323, HELIO 250, HELIO 251, SYN 045, SYN 3950HO, MG 305, MG 360, AGUARÁ 04, AGUARÁ 06, 
PARAÍSO 20, GNZ NEON, HLA 2012 e M734, que foi utilizado como testemunha por ser um material comercial de alta qualidade). $\mathrm{O}$ delineamento experimental utilizado foi de blocos ao acaso com quatro repetições. As parcelas continham quatro linhas de 5 metros de comprimento, com espaçamento de 0,8 m entre linhas. Foram aplicados $400 \mathrm{~kg} \mathrm{ha}^{-1}$ de 4-30-16 como adubação de base e $60 \mathrm{~kg} \mathrm{ha}^{-1}$ de $\mathrm{N}$ como adubação de cobertura nos três ensaios.

Restos culturais foram incorporados ao solo através de arado de discos de 32', Posteriormente usou-se uma grade niveladora de 20' para gradagem. Em pré-emergência, aplicou-se o herbicida Trifluralina na dosagem $1,2 \mathrm{~L} \mathrm{ha}^{-1}$.

As avaliações referentes aos sintomas da presença de alternária foram realizadas em cada um dos três ensaios, a partir dos 35 dias após emergência. Cinco avaliações, espaçadas em quinze dias foram realizadas ao longo do ciclo da cultura.

Para fins de análise, as duas linhas externas foram consideradas bordaduras, a fim de reduzir influências ambientais. As duas linhas centrais foram consideradas para as análises e cinco plantas de cada linha foram avaliadas, resultando na análise de dez plantas por parcela. Foram avaliados os terços inferiores, médios e superiores de cada planta de acordo com a severidade da doença. A escala diagramática utilizada (Figura 1) foi desenvolvida especificamente para a Mancha-de-alternária em girassol, permitindo uma avaliação acurada (LEITE; AMORIM, 2002). Foram atribuídas notas de 0 a 9 para cada terço de cada planta, sendo $0=$ ausência de doença, $1=0,03 \%, 2=0,2 \%$ e assim por diante até a nota $9=66 \%$ da área foliar com sintomas.

Os dados gerados deram origem a uma tabela e foi calculada a variável área abaixo da curva de progresso da doença (AACPD) conforme descrito por Campbell e Madden (1990). Menores valores de AACPD caracterizam menor severidade da doença.

Os dados obtidos foram submetidos à análise de variância através do programa Genes (CRUZ, 1997). Usou-se o teste Scott-Knott com significância de 1\% (Scott \& Knott, 1974) para agrupar as médias. A partir do uso deste teste, os resultados de AACPD dos genótipos podem ser comparados entre si. Letras iguais indicam que não há diferença estatística entre os resultados. Letras diferentes, por sua vez, indicam diferença estatística entre os dados obtidos. As letras 
maiúsculas comparam o mesmo genótipo nos diferentes ambientes, enquanto as letras minúsculas comparam os genótipos dentro de um ambiente.

\subsection{RESULTADOS E DISCUSSÃO}

A interação genótipo-ambiente foi significativa, possibilitando a comparação da severidade da doença nos materiais entre os ambientes (Tabela 1). O ensaio CPAC 01 foi o que obteve as maiores médias de AAPCD, apontando maior severidade da doença para as três partes avaliadas, terço inferior $(301,198)$, terço médio $(167,123)$ e terço superior $(25,617)$. O ensaio Fazenda Sucupira apresentou médias de 265,555, 44,0 e 2,4, para os terços inferior, médio e superior, respectivamente.

O ensaio CPAC 02, iniciado aproximadamente um mês depois, foi o que apresentou as menores médias nos terços inferior $(190,713)$ e médio $(21,7)$. O terço superior $(3,2)$ ficou um pouco acima do encontrado no ensaio Fazenda Sucupira. A menor presença de doença neste ambiente pode estar relacionada com o clima menos favorável ao desenvolvimento da mesma durante a condução do ensaio, uma vez que houve menor quantidade de chuva e menor umidade média do ar, quando comparado com os outros ensaios.

Os resultados da AACPD evidenciam variação de severidade existente entre as partes da planta, sendo o terço inferior mais atacado quando comparado aos terços médio e inferior, coerente com o observado por Leite (1997), que aponta maior intensidade da doença no terço inferior da cultura. Com exceção do ensaio CPAC 02, houve diferença significativa entre os genótipos.

No CPAC 01, o genótipo MG 360 apresentou baixos valores de AACPD, sendo o de menor valor para o terço inferior $(260,625)$, indicando menor incidência de doença quando comparado com a testemunha M734 (315,200), da qual foi diferente estatisticamente para este terço. Os genótipos CF 101, ADV 5504, BRS G42, HELIO 250, SYN 3950HO, BRS 323, GNZ NEON, HELIO 251, AGUARÁ 06 e AGUARÁ 04 foram semelhantes estatisticamente a MG 360 para o terço inferior. Por outro lado, SYN 045 apresentou o maior valor numérico $(372,750)$ 
para este terço, sendo semelhante estatisticamente à testemunha e aos genótipos HLA 2012, MG 305 e PARAISO 20.

No ensaio Fazenda Sucupira, o genótipo BRS G42 obteve a menor severidade para o terço inferior (196,500), sendo diferente estatisticamente da testemunha M734 (285,000) e semelhante estatisticamente aos materiais CF 101, ADV 5504, HELIO 250, SYN 3950HO, BRS 323, HELIO 251, AGUARÁ 06 e AGUARÁ 04. O genótipo HLA 2012 obteve o maior valor de AACPD para a parte inferior $(348,500)$, sendo estatisticamente semelhante à testemunha e aos genótipos MG 360, GNZ NEON, MG 305, PARAISO 20 e SYN 045.

No CPAC 02, apesar de não haver diferença significativa entre os genótipos, destacam-se os materiais AGUARÁ $06(163,125 ; 9,4 ; 1,9)$ e SYN 3950HO $(168,750 ; 7,5 ; 1,9)$, por terem apresentado baixos valores de AACPD para os terços inferior, médio e superior, respectivamente. O genótipo BRS G42 também obteve baixo valor numérico para a parte inferior $(178,125)$.

Maldaner (2009) encontrou valores para AACPD em girassol de aproximadamente 1600 em 2008. Loose et al. (2012) observaram AACPD de 1201,91 para o ensaio semeado em janeiro na safra 2007/2008. Tais resultados demonstram a baixa severidade de Mancha-de-alternária nos três ambientes avaliados do presente estudo.

Temperaturas entre 25 a $30^{\circ} \mathrm{C}$ e alta umidade relativa são fatores que contribuem para o aumento da severidade da doença. No presente estudo, os valores de temperatura média ao longo dos ensaios foram $20,74^{\circ} \mathrm{C}, 20,24^{\circ} \mathrm{C}$ e $19,3^{\circ} \mathrm{C}$, para CPAC 01, CPAC 02 e Fazenda Sucupira, respectivamente, indicando condições climáticas menos favoráveis ao desenvolvimento da Mancha-de-alternária.

O desempenho dos genótipos variou de acordo com o ambiente. SYN 045, por exemplo, diferiu estatisticamente nos três ambientes, obtendo maiores valores de AACPD no ensaio CPAC 01 e baixos valores no CPAC 02 . 


\subsection{CONCLUSÕES}

Os valores de AACPD encontrados foram baixos, indicando pouca doença. As condições ambientais não favoreceram a Mancha-de-alternária.

Houve interação genótipo-ambiente significativa. O ensaio CPAC 02 apresentou as menores médias de AACPD nos terços inferior e médio.

Os resultados da AACPD, em cada ambiente, evidenciam variação entre as partes da planta. O terço inferior apresentou maiores valores para AACPD quando comparado com os terços médio e inferior.

Os genótipos CF 101, ADV 5504, BRS G42, HELIO 250, SYN 3950HO, BRS 323, HELIO 251, AGUARÁ 06 e AGUARÁ 04 expressaram menores valores de AACPD no terço inferior, diferindo estatisticamente da testemunha M734. 


\subsection{TABELAS E FIGURAS}

Tabela 1. Valores médios de área abaixo da curva de progresso da doença (AACPD) submetidos ao teste de Scott-Knott a 1\%, no Distrito Federal, Brasil, 2014.

\begin{tabular}{|c|c|c|c|c|c|c|c|c|c|}
\hline \multirow[b]{2}{*}{ Genótipo } & \multicolumn{3}{|c|}{ CPAC 01 } & \multicolumn{3}{|c|}{ Fazenda Sucupira } & \multicolumn{3}{|c|}{ CPAC 02} \\
\hline & $\begin{array}{l}\text { AACPD } \\
\text { inferior }\end{array}$ & $\begin{array}{c}\text { AACPD } \\
\text { médio }\end{array}$ & $\begin{array}{l}\text { AACPD } \\
\text { superior }\end{array}$ & $\begin{array}{l}\text { AACPD } \\
\text { inferior }\end{array}$ & $\begin{array}{l}\text { AACPD } \\
\text { médio }\end{array}$ & $\begin{array}{l}\text { AACPD } \\
\text { superior }\end{array}$ & $\begin{array}{l}\text { AACPD } \\
\text { inferior }\end{array}$ & $\begin{array}{c}\text { AACPD } \\
\text { médio }\end{array}$ & $\begin{array}{l}\text { AACPD } \\
\text { superior }\end{array}$ \\
\hline CF 101 & $286,125 \mathrm{Ab}$ & $133,125 \mathrm{Ac}$ & $20,625 \mathrm{Ac}$ & $255,000 \mathrm{Ab}$ & $40,0 \mathrm{Bb}$ & $0,0 \mathrm{Aa}$ & $195,000 \mathrm{Ba}$ & $22,5 \mathrm{Ba}$ & $7,5 \mathrm{Aa}$ \\
\hline ADV 5504 & $286,325 \mathrm{Ab}$ & $165,950 \mathrm{Ac}$ & $48,750 \mathrm{Ab}$ & $207,275 \mathrm{Bb}$ & $10,0 \mathrm{Bb}$ & $0,0 \mathrm{Ba}$ & $191,250 \mathrm{Ba}$ & $28,1 \mathrm{Ba}$ & $5,6 \mathrm{Ba}$ \\
\hline BRS G42 & $275,825 \mathrm{Ab}$ & $150,200 \mathrm{Ac}$ & $46,875 \mathrm{Ab}$ & $196,500 \mathrm{Bb}$ & $37,5 \mathrm{Bb}$ & $10,0 \mathrm{Ba}$ & $178,125 \mathrm{Ba}$ & $18,8 \mathrm{Ba}$ & $3,8 \mathrm{Ba}$ \\
\hline M734 (T) & $315,200 \mathrm{Aa}$ & $176,450 \mathrm{Ac}$ & $26,250 \mathrm{Ac}$ & $285,000 \mathrm{Aa}$ & $37,5 \mathrm{Bb}$ & $0,0 \mathrm{Ba}$ & $192,200 \mathrm{Ba}$ & $30,0 \mathrm{Ba}$ & $3,8 \mathrm{Ba}$ \\
\hline HELIO 250 & $303,750 \mathrm{Ab}$ & $168,750 \mathrm{Ac}$ & $13,125 \mathrm{Ac}$ & $244,000 \mathrm{Bb}$ & $51,0 \mathrm{Bb}$ & 7,5 Aa & $208,125 \mathrm{Ba}$ & $20,6 \mathrm{Ba}$ & $0,0 \mathrm{Aa}$ \\
\hline SYN $3950 \mathrm{HO}$ & $294,375 \mathrm{Ab}$ & $166,875 \mathrm{Ac}$ & $18,750 \mathrm{Ac}$ & $216,000 \mathrm{Bb}$ & $63,8 \mathrm{Ba}$ & $0,0 \mathrm{Aa}$ & $168,750 \mathrm{Ba}$ & 7,5 Ca & 1,9 Аa \\
\hline BRS 323 & $286,875 \mathrm{Ab}$ & $191,250 \mathrm{Ab}$ & $43,125 \mathrm{Ab}$ & $220,275 \mathrm{Bb}$ & $40,5 \mathrm{Bb}$ & $12,5 \mathrm{Ba}$ & $206,250 \mathrm{Ba}$ & $52,5 \mathrm{Ba}$ & $13,1 \mathrm{Ba}$ \\
\hline MG 360 & $260,625 \mathrm{Ab}$ & $146,250 \mathrm{Ac}$ & $16,875 \mathrm{Ac}$ & $287,775 \mathrm{Aa}$ & $50,0 \mathrm{Bb}$ & $0,0 \mathrm{Aa}$ & $191,250 \mathrm{Ba}$ & $17,1 \mathrm{Ba}$ & $3,8 \mathrm{Aa}$ \\
\hline GNZ NEON & $275,625 \mathrm{Ab}$ & $142,500 \mathrm{Ac}$ & $3,750 \mathrm{Ac}$ & $325,000 \mathrm{Aa}$ & $34,0 \mathrm{Bb}$ & $2,5 \mathrm{Aa}$ & $204,375 \mathrm{Ba}$ & $20,6 \mathrm{Ba}$ & $3,8 \mathrm{Aa}$ \\
\hline HLA 2012 & $326,250 \mathrm{Aa}$ & $187,500 \mathrm{Ab}$ & $35,625 \mathrm{Ab}$ & $348,500 \mathrm{Aa}$ & $98,5 \mathrm{Ba}$ & $2,5 \mathrm{Ba}$ & $198,750 \mathrm{Ba}$ & $16,9 \mathrm{Ca}$ & $1,9 \mathrm{Ba}$ \\
\hline MG 305 & $321,000 \mathrm{Aa}$ & $158,625 \mathrm{Ac}$ & $15,375 \mathrm{Ac}$ & $330,500 \mathrm{Aa}$ & $66,0 \mathrm{Ba}$ & $0,0 \mathrm{Aa}$ & $174,375 \mathrm{Ba}$ & $15,0 \mathrm{Ca}$ & $1,9 \mathrm{Aa}$ \\
\hline HELIO 251 & $305,825 \mathrm{Ab}$ & $174,375 \mathrm{Ac}$ & $18,750 \mathrm{Ac}$ & $240,775 \mathrm{Bb}$ & $27,8 \mathrm{Bb}$ & $0,0 \mathrm{Aa}$ & $198,750 \mathrm{Ba}$ & $26,3 \mathrm{Ba}$ & $1,9 \mathrm{Aa}$ \\
\hline AGUARÁ 06 & $296,625 \mathrm{Ab}$ & $144,750 \mathrm{Ac}$ & $5,625 \mathrm{Ac}$ & $211,500 \mathrm{Bb}$ & $10,5 \mathrm{Bb}$ & $0,0 \mathrm{Aa}$ & $163,125 \mathrm{Ba}$ & $9,4 \mathrm{Ba}$ & 1,9 Аa \\
\hline AGUARÁ 04 & $275,625 \mathrm{Ab}$ & $123,750 \mathrm{Ac}$ & $9,375 \mathrm{Ac}$ & $257,000 \mathrm{Ab}$ & $32,0 \mathrm{Bb}$ & $0,0 \mathrm{Aa}$ & $197,625 \mathrm{Ba}$ & $24,4 \mathrm{Ba}$ & $0,0 \mathrm{Aa}$ \\
\hline PARAISO 20 & $336,375 \mathrm{Aa}$ & $193,125 \mathrm{Ab}$ & $22,500 \mathrm{Ac}$ & $311,275 \mathrm{Aa}$ & $72,0 \mathrm{Ba}$ & $3,5 \mathrm{Ba}$ & $198,750 \mathrm{Ba}$ & $18,8 \mathrm{Ca}$ & $0,0 \mathrm{Ba}$ \\
\hline SYN 045 & $372,750 \mathrm{Aa}$ & $250,500 \mathrm{Aa}$ & $64,500 \mathrm{Aa}$ & $312,500 \mathrm{Ba}$ & $32,5 \mathrm{Bb}$ & $0,0 \mathrm{Ba}$ & $184,700 \mathrm{Ca}$ & $18,8 \mathrm{Ba}$ & $0,0 \mathrm{Ba}$ \\
\hline Mínimo & 260,625 & 123,750 & 3,750 & 196,500 & 10,0 & 0,0 & 163,125 & 7,5 & 0,0 \\
\hline Média & 301,198 & 167,123 & 25,617 & 265,555 & 44,0 & 2,4 & 190,713 & 21,7 & 3,2 \\
\hline Máximo & 372,750 & 250,500 & 64,500 & 348,500 & 98,5 & 12,5 & 208,125 & 52,5 & 13,1 \\
\hline Desvio Padrão & 28,1895 & 30,2292 & 17,3474 & 49,4326 & 22,7227 & 4,0382 & 13,4138 & 10,1942 & 3,4040 \\
\hline Variância & 794,6493 & 913,8028 & 300,9322 & 2443,5837 & 516,3192 & 16,3073 & 179,9309 & 103,9222 & 11,5869 \\
\hline QM & 3178,59716 & 3655,21116 & 1203,72891 & 9774,33474 & 2065,27696 & 65,22917 & 719,72367 & 415,68891 & 46,34766 \\
\hline Teste F & $2,7416 * *$ & $3,3107 * *$ & $3,4675 * *$ & $7,1045^{* *}$ & $3,0695 * *$ & $4,4633 * *$ & $1,5675^{\mathrm{Ns}}$ & $2,7365 * *$ & $1,8583^{\mathrm{Ns}}$ \\
\hline$h_{a}^{2}$ & 63,52 & 69,79 & 71,16 & 85,92 & 67,42 & 77,60 & 36,20 & 63,46 & 46,19 \\
\hline
\end{tabular}

Letras maiúsculas comparam o mesmo genótipo nos diferentes ambientes. Letras minúsculas comparam os genótipos dentro do mesmo ambiente.

Letras iguais indicam que não há diferença estatística entre os resultados, enquanto letras diferentes indicam diferença estatística (Teste Scott-Knott a 1\%). 


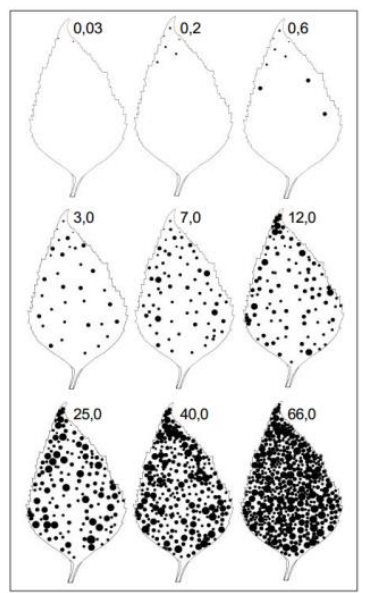

Figura 1. Escala diagramática usada para avaliar a Mancha-de-alternária em girassol. Valores em porcentagem da área foliar com sintomas (lesões necróticas e halo clorótico). 


\subsection{REFERÊNCIAS BIBLIOGRÁFICAS}

CAMPBELL, C.L.; MADDEN, L.V. Introduction to plant disease epidemiology. New York. J. Wiley \& Sons. 1990.

CASTRO, C.; CASTIGLIONI, V.B.R.; BALlA, A. A cultura do girassol. Circular Técnica, EMBRAPA-CNPSo, n.13, 1996, 38p.

CRUZ, C.D. Programa Genes: aplicativo computacional em genética e estatística. Versão Windows - 2007. Viçosa: editora UFV, 1997. v.1. 442p.

DAVET, P.; PÉRÈS, A.; REGNAULT, Y.; TOURVIEILLE, D.; PENAUD, A. Les maladies du tournesol. Paris: CETIOM, 1991. 72p.

LEITE, R.M.V.B.C.; AMORIM, L. Elaboração e validação de escala diagramática para mancha de Alternaria em girassol. Summa Phytopathologica, v.28, n.1, p.14-19, 2002.

LEITE, R.M.V.B.C. Doenças do girassol. (Circular Técnica, 19). Londrina: Embrapa-CNPSo, 1997. 68p.

LOOSE, L.H.; HELDWEIN, A.B.; MALDANER, I.C.; LUCAS, D.D.P.; HINNAH, F.D.; BORTOLUZZI, M.P. Severidade de ocorrência das manchas de alternária e septoriose em girassol semeado em diferentes épocas no Rio Grande do Sul. Bragantia, v.71, p.282-289, 2012.

MALDANER, I. C. Irrigação e aplicação de fungicida na ocorrência de doenças e produtividade do girassol. 2009. 93f. Dissertação (Mestrado em Engenharia Agrícola) Universidade Federal de Santa Maria, Santa Maria, RS.

SCOTT, A.J.; KNOTT, M. Accouter analysis methods for grouping means in the analysis of variants. Biometrics, 30: p.507-512, 1974.

ZIMMER, D.E.; HOES, J.A. Diseases. In: CARTER, J.F. (Eds.). Sunflower science and technology. Madison: American Society of Agronomy, 1978. p.225-262. 


\section{CAPÍTULO IV}

AVALIAÇÃO DA QUALIDADE DE SEMENTES DE GIRASSOL NO CERRADO DO DISTRITO FEDERAL

EVALUATION OF SUNFLOWER SEEDS QUALITY IN THE BRAZILIAN SAVANNAH AT FEDERAL DISTRICT, BRAZIL 


\section{AVALIAÇÃO DA QUALIDADE DE SEMENTES DE GIRASSOL NO CERRADO DO DISTRITO FEDERAL}

\subsection{RESUMO}

O presente trabalho teve por objetivo a avaliação da qualidade fisiológica de sementes de girassol provenientes de três ambientes, dois na área experimental da Embrapa - Centro de Pesquisa Agropecuária dos Cerrados, em Planaltina, DF, situada a $15^{\circ} 35^{\prime} 30^{\prime \prime}$ de latitude Sul, $47^{\circ}$ 42' 30" de longitude Oeste e a altitude de $1.007 \mathrm{~m}$ e um na área experimental da Embrapa Produtos e Mercado, no Recanto das Emas, DF, a 15 54' 53" de latitude Sul, 48 02' 14" de longitude Oeste e a altitude de $1.254 \mathrm{~m}$. O delineamento experimental utilizado foi de blocos ao acaso. Foram considerando nove testes de qualidade de sementes: Teste padrão de germinação (TPG) em areia; Teste padrão de germinação (TPG) em papel; Peso de matéria verde e de matéria seca (PMV e PMS); Condutividade elétrica (CE); Lixiviados de potássio (LIX); Envelhecimento acelerado (EA); Emergência de plântulas em campo (EC) e; Índice de velocidade de emergência (IVE) em campo. As sementes avaliadas foram obtidas através de polinização aberta de híbridos simples de 16 genótipos. A partir da análise de variância, constatou-se que não houve significância entre os locais. As características estudadas apontaram diferença significativa entre os genótipos avaliados, exceto TPG em papel, que não obteve diferença estatística entre genótipos em nenhum ambiente. Os genótipos BRS 323, MG 360 e HLA 2012 obtiveram os melhores resultados para os testes EC e IVE. Os melhores desempenhos no teste CE foram dos genótipos GNZ NEON, M734, SYN 3950HO, AGUARÁ 06, SYN 045, MG 360 e HELIO 251. Para o teste LIX, destacaram-se em qualidade os genótipos GNZ NEON, SYN 045, AGUARÁ 06 e M734. Os pares CE e LIX e EC e IVE detiveram as maiores correlações genotípica e fenotípica.

Palavras-chave: Helianthus annuus L., germinação, testes de vigor. 
EVALUATION OF SUNFLOWER SEEDS QUALITY IN THE BRAZILIAN SAVANNAH AT FEDERAL DISTRICT, BRAZIL

\subsection{ABSTRACT}

This study aimed to evaluate the physiological quality of sunflower seeds from three environments, two of them were conducted at Embrapa Cerrados (Federal District - Brazil) located at $15^{\circ} 35^{\prime} 30^{\prime \prime} \mathrm{S}$ latitude, $47^{\circ} 42^{\prime} 30^{\prime \prime} \mathrm{W}$ longitude and $1.007 \mathrm{~m}$ above sea level, and the other one at Embrapa Produtos e Mercado (Federal District - Brazil), located at 15' 54' 53" S latitude, $48^{\circ} 02^{\prime} 14^{\prime \prime} \mathrm{W}$ longitude and $1.254 \mathrm{~m}$ above sea level. A complete randomized block design was used. Nine characters were evaluated: germination (TPG) in sand; germination (TPG) on paper; Weight of green matter and dry matter (PMV and PMS); Electrical conductivity (CE); potassium leachate (LIX); Accelerated aging (EA); Field emergence (EC) and; emergence speed (IVE) in the field. It was found that there was no significance between locations. Except for TPG paper, the characteristics studied showed significant differences between genotypes. The genotypes BRS 323, MG 360 and HLA 2012 achieved the best results for the EC and IVE tests. The best performances in the CE test were from genotypes GNZ NEON, M734, SYN 3950HO, AGUARÁ 06, SYN 045, MG 360 and HELIO 251. For LIX test, the best results were from GNZ NEON, SYN 045, AGUARÁ 06 and M734. CE and LIX, and, EC and IVE, detained the highest genotypic and phenotypic correlations.

Key words: Helianthus annuus L., germination, vigor tests. 


\subsection{INTRODUÇÃO}

O girassol (Helianthus annuus L.) é uma importante cultura anual, originária da América do Norte, que recebe destaque pela produção de óleo de alta qualidade. Esta cultura é caracterizada também pela grande adaptabilidade, sendo apresentada como uma opção rentável para o cultivo em safrinha. Castro e Farias et al. (2005) apontam o girassol como detentor de características positivas, como maior tolerância a condições de seca, frio e calor, comparado com outras espécies.

Uma das etapas para uma produção eficaz é garantir a qualidade das sementes que são utilizadas, fazendo com o que o potencial da cultura possa ser expresso. Contribuem para a determinação de qualidade das sementes os aspectos genéticos, físicos, fisiológicos e sanitários, uma vez que múltiplas características podem interagir e influenciar o desempenho dos materiais (MARCOS FILHO, 1999).

Testes de germinação e vigor são realizados de forma complementar, possibilitando conclusões de maior respaldo a respeito da qualidade das sementes, uma vez que estes caracterizam fatores fundamentais para estimar o comportamento das sementes no campo. Boa germinação e bom vigor contribuem para uma produtividade competitiva. Dois importantes exemplos de teste de vigor rápidos e eficazes são os testes de condutividade elétrica e de lixiviação de potássio, que fornecem informações relacionadas à deterioração dos materiais, sendo embasados na permeabilidade das membranas. Ambos os testes apresentam melhor resultado quando menor valor é encontrado, pois isto significa menor lixiviação de solutos, indicando integridade das membranas celulares, enquanto maiores valores designam sementes de baixo vigor (FAGIOLI, 1997).

Estudos relacionados às características que influenciam a produção e o desempenho dos genótipos devem ser constantemente realizados. O conhecimento dos genótipos auxilia o processo de seleção e os programas de melhoramento. As correlações são um exemplo de ferramenta que facilita o processo de seleção. De acordo com Santos e Vencovsky (1986), as correlações possibilitam a obtenção de sucesso através de seleção simultânea de características. 
Informações sobre adaptação de genótipos e seus desempenhos em diferentes ambientes proporcionam base fundamental para a pesquisa de melhoramento genético e permitem a constante procura por materiais superiores. Estudos a respeito da qualidade de sementes de girassol são relevantes, visto a potencialidade da espécie.

\subsection{MATERIAL E MÉTODOS}

Foram realizados três experimentos no Cerrado do Distrito Federal. O primeiro (CPAC 1), semeado em 20 de fevereiro de 2014, foi na área experimental da Embrapa - Centro de Pesquisa

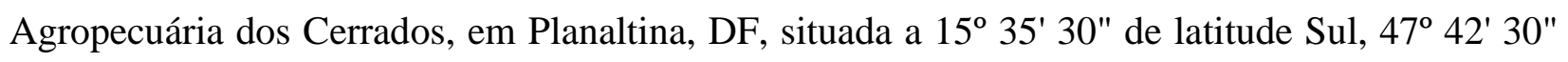
de longitude Oeste e a altitude de 1.007 m. O segundo ensaio (SNT), de 23 de fevereiro de 2014, foi na área experimental da Embrapa Produtos e Mercado, no Recanto das Emas, DF, a 15 54' 53" de latitude Sul, 48 02' 14" de longitude Oeste e a altitude de 1.254 m. O terceiro (CPAC 2), também na área da Embrapa Cerrados, foi iniciado no dia 25 de março de 2014.

Durante o experimento, dados meteorológicos foram coletados na Estação Meteorológica da Embrapa Cerrados. Para o ensaio CPAC 1, obteve-se temperatura mínima, média e máxima do ar de $8,4^{\circ} \mathrm{C}, 20,74^{\circ} \mathrm{C}$ e $30,8^{\circ} \mathrm{C}$, respectivamente; umidade média do ar de $73,22 \%$; e um somatório de 479,7 mm de chuva durante todo o período. O ensaio CPAC 2, iniciado em 25 de março, obteve temperatura mínima, média e máxima do ar de $8,4^{\circ} \mathrm{C}, 20,24^{\circ} \mathrm{C}$ e $30,8^{\circ} \mathrm{C}$, respectivamente; umidade média do ar de 68,29\%; e um somatório de 181,7 mm de chuva. Para o ensaio SNT, usaram-se os dados da Estação Meteorológica da Fazenda Água Limpa - FAL/UnB e encontrouse temperatura mínima, média e máxima do ar de $6,2^{\circ} \mathrm{C}, 19,3^{\circ} \mathrm{C}$ e $30,5^{\circ} \mathrm{C}$, respectivamente; umidade média do ar de 79,2\%; e um somatório de $637 \mathrm{~mm}$ de chuva durante todo o ensaio.

As sementes avaliadas foram obtidas através de polinização aberta de híbridos simples de 16 genótipos: CF 101, ADV 5504, BRS G42, M734, HELIO 250, SYN 3950HO, BRS 323, MG 360, GNZ NEON, HLA 2012, MG 305, HELIO 251, AGUARÁ 06, AGUARÁ 04, PARAISO 20 e SYN 045. O genótipo M734 foi utilizado como testemunha por ser um material comercial de alta qualidade. O delineamento experimental utilizado foi de blocos ao acaso com quatro repetições. As parcelas continham quatro linhas de 5 metros de comprimento, com espaçamento 
de $0,8 \mathrm{~m}$ entre linhas. Foram aplicados $400 \mathrm{~kg} \mathrm{ha}^{-1}$ de 4-30-16 como adubação de base e $60 \mathrm{~kg} \mathrm{ha}^{-1}$ de $\mathrm{N}$ como adubação de cobertura nos três ensaios.

Restos culturais foram incorporados ao solo através de arado de discos de 32'. Posteriormente usou-se uma grade niveladora de 20" para gradagem. Em pré-emergência, aplicou-se o herbicida Trifluralina na dosagem 1,2 $\mathrm{L} \mathrm{ha}^{-1}$.

Nove testes de qualidade de sementes foram realizados para caracterizar os materiais: Teste padrão de germinação (TPG) em areia; Teste padrão de germinação (TPG) em papel; Peso de matéria verde e de matéria seca (PMV e PMS); Condutividade elétrica (CE); Lixiviados de potássio (LIX); Envelhecimento acelerado (EA); Emergência de plântulas em campo (EC) e; Índice de velocidade de emergência (IVE) em campo. Os testes TPG em areia, LIX, EC e IVE foram realizados na Embrapa - Centro de Pesquisa Agropecuária dos Cerrados. Os testes TPG em papel, PMV, PMS, CE e EA foram realizados no Laboratório de Sementes da Faculdade de Agronomia e Veterinária - FAV, da Universidade de Brasília - UnB, Campus Universitário Darcy Ribeiro, Brasília, DF, em 2014. Para cada teste, foram utilizadas quatro amostras de 50 sementes, totalizando 200 sementes de cada um dos 16 genótipos.

Para TPG em areia, utilizaram-se tubetes contendo areia grossa. O substrato foi umedecido com água, diariamente, através de aspersores. Foi feita a contagem das plântulas normais no quinto dia após o plantio. Os resultados foram expressos em porcentagem.

O TPG em papel foi feito com base na contagem de plântulas normais, seguindo prescrição das Regras para Análise de Sementes (BRASIL, 2009), após estas serem mantidas em rolo de papel toalha, umedecido na quantidade de 2,5 vezes o peso do substrato seco e mantidas a $25^{\circ} \mathrm{C}$. Os resultados foram expressos em porcentagem. Para avaliar o peso de matéria verde (PMV) e o peso de matéria seca (PMS), foram utilizadas as plântulas normais obtidas pelo TPG em papel. Para PMV, as plântulas foram pesadas em balança analítica, gerando resultados expressos em gramas. Posteriormente, estas plântulas foram armazenadas por 24 horas em estufa de ventilação forçada a $70^{\circ} \mathrm{C}$, quando foram retiradas e pesadas, dando origem ao PMS, expresso também em gramas. 
Para obter dados de condutividade elétrica (CE), as amostras foram inicialmente pesadas em uma balança. Posteriormente, cada amostra foi colocada em um copo plástico juntamente com $75 \mathrm{ml}$ de água destilada. Os copos permaneceram em condição de temperatura controlada, a $25^{\circ} \mathrm{C}$, por 24 horas (HAMPTON; TEKRONY, 1995; VIEIRA; KRZYZANOWSKI, 1999). A leitura de condutividade foi feita através do condutivímetro digital CG 2000 da Marca Gehaka, versão: 6.11. Os resultados finais foram expressos em $\mu \mathrm{S}$ cm-1g-1. Após a leitura de condutividade elétrica, o líquido proveniente de cada um dos copos plásticos, contendo anteriormente água e sementes, foi submetido à leitura para avaliação de lixiviados de potássio (LIX) através do fotômetro de chamas B 462 Micronal. Os resultados finais foram expressos em $\mathrm{mg} / \mathrm{g}$.

O teste de envelhecimento acelerado (EA) foi realizado em caixas plásticas adaptadas, tipo gerbox, com as sementes dispostas em camada única sobre tela de aço inox. As caixas, contendo $40 \mathrm{ml}$ de água sob a tela foram colocadas em câmara por 72 horas, com temperatura de $41^{\circ} \mathrm{C}$. A avaliação única foi realizada após quatro dias (MARCOS-FILHO, 1999).

Para avaliar a emergência de plântulas em campo (EC), as amostras foram semeadas com distância de 10 centímetros entre linhas. Foi utilizado o delineamento ao acaso e foi feita a contagem de plântulas emergentes aos sete dias após a semeadura (BRASIL, 2009), sendo os resultados expressos em porcentagem. Para o índice de velocidade de emergência (IVE), utilizouse o mesmo experimento de EC. Foram feitas contagens do quinto ao décimo dia após o plantio, seguindo-se as recomendações de Nakagawa (1994; 1999), utilizando a fórmula - IVE = número de plântulas emergidas / dia da contagem - para obtenção da média dentro de cada repetição.

Os dados obtidos foram submetidos à análise de variância através do programa Genes (CRUZ, 1997). Primeiramente foi feita a análise conjunta dos ambientes, porém não houve significância entre os mesmos. Portanto, foram realizadas análises de variância por ambiente. Feito isto, usou-se o teste Scott-Knott com significância de 1\% (SCOTT; KNOTT, 1974) para agrupar as médias e obtiveram-se também as correlações genotípicas, fenotípicas e de ambiente, segundo Kempthorne (1966).

A partir do uso do teste Scott-Knott, os resultados das médias dos genótipos podem ser comparados entre si, considerando cada uma das variáveis, que correspondem aos testes 
realizados. Letras iguais indicam que não há diferença estatística entre os resultados. Letras diferentes, por sua vez, indicam diferença estatística entre os dados obtidos.

\subsection{RESULTADOS E DISCUSSÃO}

A primeira análise de variância foi realizada de forma conjunta, considerando os três ambientes em que foram desenvolvidos os ensaios. Não houve significância entre os locais. Com isso, foi realizada a análise de variância por ambiente, que por sua vez, evidencia diferenças estatísticas entre as médias dos genótipos para todas as variáveis avaliadas, exceto para TPG em papel, que não obteve diferença estatística entre genótipos em nenhum ambiente (Tabelas 1, 2 e 3). Essa falta de diferença pode ser decorrente das condições favoráveis e controladas de todo o ensaio, uma vez que TPG em papel foi realizado em laboratório. Albuquerque et al. (2001) encontraram efeito significativo dos genótipos para os testes de germinação, envelhecimento acelerado, emergência de plântulas, condutividade elétrica e lixiviados de potássio para sementes de girassol, o que corrobora o apresentado pelo presente estudo.

No ensaio CPAC 01 (Tabela 1), observa-se que para a EC e IVE, os genótipos BRS 323 (33,00\% e 26,09), MG 360 (32,50\% e 22,08) e HLA 2012 (30,75\% e 21,52) superaram a testemunha M743 (30,50\% e 20,25) e foram semelhantes estatisticamente. Em relação ao TPG em areia, os genótipos CF 101, ADV 5504, BRS G42, HELIO 250, BRS 323, MG 360, HLA 2012, MG 305, HELIO 251, AGUARÁ 04 e PARAISO 20 foram superiores em relação à testemunha, diferindo estatisticamente da mesma. Tanto para EC quanto para TPG em areia, os valores foram dados com base nas 50 sementes utilizadas para cada tratamento, o que significa dizer que o valor máximo seria 50\%. Em PMS, os genótipos ADV 5504, BRS G42, HELIO 250, BRS 323, HLA 2012 e SYN 045 foram superiores em valor, porém estatisticamente semelhantes à testemunha M743 (0,42 g). Em PMV, somente o material HLA 2012 (0,12 g) diferiu estaticamente dos demais, sendo o genótipo com o maior valor apresentado. Quanto ao teste de envelhecimento acelerado, BRS 323 (93,00\%) e BRS G42 (91,50\%) superaram e foram estatisticamente diferentes da testemunha M734 (75,50\%). 
Ainda em relação ao CPAC 01, nota-se que os testes de Condutividade elétrica e Lixiviados de Potássio obtiveram as maiores diferenças estatísticas entre os genótipos. Considerando o teste CE, os genótipos BRS G42 (61,13 $\mu \mathrm{S}$ cm-1g-1), SYN 3950HO (53,79 $\mu \mathrm{S}$ cm-1g-1), GNZ NEON (39,30 $\mu \mathrm{S}$ cm-1g-1), AGUARÁ 06 (54,94 $\mu \mathrm{S}$ cm-1g-1) e SYN 045 (50,36 $\mu \mathrm{S}$ cm-1g-1) apresentaram qualidade fisiológica superior aos demais, sendo estatisticamente semelhantes à testemunha $(50,37 \mu \mathrm{S} \mathrm{cm}-1 \mathrm{~g}-1)$. Para LIX, os genótipos SYN 3950HO, GNZ NEON, AGUARÁ 06 e SYN 045 foram estatisticamente semelhantes à testemunha M743 (1,16 mg g-1), apresentando os menores valores e consequentemente os melhores desempenhos em relação a esta característica.

No ensaio Fazenda Sucupira (Tabela 2), observa-se que não houve diferença estatística para os testes TPG em areia e EC. Para IVE, houve semelhança estatística entre a testemunha e os genótipos CF 101, BRS 323, HLA 2012, HELIO 251, AGUARÁ 06, AGUARÁ 04 e PARAISO 20, correspondendo aos melhores desempenhos neste teste. Em PMV, os genótipos HELIO 250 (0,54), GNZ NEON (0,56), MG 305 (0,58), HELIO 251 (0,58), AGUARÁ $04(0,55)$ e SYN 045 $(0,58)$ obtiveram valores superiores e diferiram estatisticamente dos outros materiais. Em PMS, HELIO 250 e PARAISO 20 foram os genótipos de maior valor numérico, divergindo estatisticamente dos demais. No teste EA, encontram-se maiores valores para a testemunha M734 $(83,50 \%)$ e para os genótipos MG 360 (84,50\%), HELIO 251 (87,50\%) e SYN 045 (80,00\%), sendo que os quatro materiais citados foram semelhantes estatisticamente. Para CE, houve semelhança estatística entre a testemunha M734 (42,41 $\mu \mathrm{S}$ cm-1g-1) e os genótipos MG 360 (49,46 $\mu \mathrm{S}$ cm-1g-1), GNZ NEON (31,80 $\mu \mathrm{S}$ cm-1g-1), HELIO 251 (49,76 $\mu \mathrm{S}$ cm-1g-1) e SYN 045 (45,34 $\mu \mathrm{S}$ cm-1g-1), correspondendo aos materiais com os menores valores encontrados para esta variável. Para LIX, os genótipos BRS G42, MG 360, GNZ NEON, HELIO 251 e SYN 045 assemelharam-se à testemunha e corresponderam aos menores valores encontrados.

No ensaio CPAC 02 (Tabela 3), para TPG em areia, os genótipos BRS 323 (49,25\% e 31,39) e PARAISO $20(48,50 \%$ e 31,21), foram estatisticamente semelhantes, porém superiores em valor quando comparados com a testemunha M734 (47,75\% e 31,20). Os maiores valores encontrados para PMV foram dos genótipos BRS G42, BRS 323, MG 360, GNZ NEON, HLA 2012, MG 305, AGUARÁ 04, SYN 045 e da testemunha M734, todos semelhantes estatisticamente. Para PMS, os maiores valores foram dos materiais BRS G42, MG 360, 
AGUARÁ 06, AGUARÁ 04 e PARAISO 20, que foram diferentes estatisticamente dos demais. O teste CE apresentou resultados de menor valor para a testemunha $(36,24 \mu \mathrm{S} \mathrm{cm}-1 \mathrm{~g}-1)$ e os genótipos SYN 3950HO (45,67 $\mu \mathrm{S}$ cm-1g-1), MG 360 (48,63 $\mu \mathrm{S}$ cm-1g-1), GNZ NEON (38,37 $\mu \mathrm{S}$ cm-1g-1), HELIO 251 (40,55 $\mu \mathrm{S}$ cm-1g-1), AGUARÁ 06 (31,68 $\mu \mathrm{S}$ cm-1g-1) e SYN 045 (36,43 $\mu \mathrm{S} \mathrm{cm-1g-1),} \mathrm{todos} \mathrm{se} \mathrm{assemelhando} \mathrm{estatisticamente} \mathrm{entre} \mathrm{si.} \mathrm{Para} \mathrm{LIX,} \mathrm{encontrou-se}$ semelhança estatística entre a testemunha, GNZ NEON, AGUARÁ 06 e SYN 045, sendo este grupo o que apresentou os menores valores numéricos. Em EA, os genótipos CF 101, ADV 5504, BRS 323, MG 360, HLA 2012, AGUARÁ 06 e SYN 045 foram superiores numericamente, porém estatisticamente semelhantes à testemunha M734 (80,00\%). Em EC, o maior valor encontrado foi $35,75 \%$, correspondente ao resultado da testemunha e do material HELIO 250. No teste IVE, os genótipos CF 101, BRS G42, HELIO 250 e AGUARÁ 04 obtiveram maior valor do que a testemunha, mas foram semelhantes estatisticamente à mesma.

Albuquerque et al. (2001) obtiveram 79,41 $\mu \mathrm{S}$ cm-1g-1 como melhor resultado para o teste de condutividade elétrica em sementes de girassol, o que evidencia a qualidade dos materiais avaliados neste trabalho.

De forma geral e em valores absolutos, para os três ambientes, as correlações genotípicas foram superiores às fenotípicas e ambientais. Os coeficientes fenotípicos e genotípicos com o mesmo sinal indicam ausência de erros na amostragem e avaliação, conforme apontado por Cruz et al. (2004).

Para os pares de caracteres TPG areia e PMS, TPG papel e EA, PMS e EA e, LIX e EC houve diferença de sinais entre as correlações genotípicas e ambientais nos três ambientes (Tabelas 4, 5 e 6), o que pode indicar que o ambiente favoreceu uma característica em detrimento da outra.

No CPAC 01, os pares CE e LIX $(0,9928 ; 0,9882)$ e, EC e IVE $(0,941 ; 0,942)$ detiveram as maiores correlações genotípica e fenotípica, respectivamente. Isso significa dizer que uma característica influencia a outra em mesmo sentido. No ensaio Fazenda Sucupira, o mesmo ocorreu com CE e LIX (0,9562; 0,9093) e com EC e IVE (0,926; 0,9187). Assim como nos anteriores, no CPAC 02, os pares $\operatorname{CE}$ e LIX $(0,9976 ; 0,9838)$ e, EC e IVE $(0,9881 ; 0,9856)$ obtiveram as maiores correlações genotípica e fenotípica, nesta ordem. Para os pares 
mencionados, a correlação ambiental apresentou o mesmo sinal das correlações genotípica e fenotípica, apontando que o ambiente não influenciou as variáveis e que é possível realizar seleção indireta. Com base neste trabalho, pode-se esperar, por exemplo, que cultivares com maior índice de velocidade de emergência alcancem maior porcentagem de emergência em campo.

\subsection{CONCLUSÕES}

As características estudadas no presente trabalho revelaram diferença significativa entre os genótipos avaliados, salvo TPG em papel, que não obteve diferença estatística entre genótipos em nenhum ambiente.

De modo geral, os genótipos BRS 323, MG 360 e HLA 2012 obtiveram os melhores resultados para os testes EC e IVE. O material BRS 323 teve bom desempenho para o teste de envelhecimento acelerado.

Os melhores desempenhos no teste CE foram dos genótipos GNZ NEON, M734, SYN 3950HO, AGUARÁ 06, SYN 045, MG 360 e HELIO 251. Para o teste LIX, os genótipos GNZ NEON, SYN 045, AGUARÁ 06 e M734 obtiveram melhores resultados.

Os pares CE e LIX e EC e IVE detiveram as maiores correlações genotípica e fenotípica nos três ensaios. 


\subsection{TABELAS E FIGURAS}

Tabela 1. Valores médios para o teste de padrão de germinação (TPG) em areia, teste padrão de germinação (TPG) em papel, peso de matéria verde e de matéria seca (PMV e PMS), condutividade elétrica (CE), lixiviados de potássio (LIX), envelhecimento acelerado (EA), emergência de plântulas em campo (EC) e, índice de velocidade de emergência (IVE) em campo, submetidos ao teste de Scott-Knott a 1\%. Embrapa Cerrados, Planaltina, DF, 2014 (CPAC 01).

\begin{tabular}{|c|c|c|c|c|c|c|c|c|c|}
\hline Genótipo & TPG areia & TPG papel & PMV & PMS & CE & LIX & EA & EC & IVE \\
\hline CF 101 & $48,50 \mathrm{a}$ & $94,00 \mathrm{a}$ & $0,39 \mathrm{~b}$ & $0,08 \mathrm{~b}$ & $124,04 \mathrm{a}$ & $2,84 \mathrm{a}$ & $74,50 \mathrm{~b}$ & $21,25 \mathrm{~b}$ & $17,55 \mathrm{~b}$ \\
\hline ADV 5504 & $46,00 \mathrm{a}$ & $89,00 \mathrm{a}$ & $0,43 \mathrm{a}$ & $0,08 \mathrm{~b}$ & $90,88 \mathrm{~b}$ & $2,11 \mathrm{~b}$ & $79,00 \mathrm{~b}$ & $22,50 \mathrm{~b}$ & $17,38 \mathrm{~b}$ \\
\hline BRS G42 & $46,00 \mathrm{a}$ & $94,00 \mathrm{a}$ & $0,43 \mathrm{a}$ & $0,08 \mathrm{~b}$ & $61,13 \mathrm{~d}$ & $1,62 \mathrm{c}$ & $91,50 \mathrm{a}$ & $26,50 \mathrm{a}$ & $19,14 \mathrm{a}$ \\
\hline M734 (T) & $43,50 \mathrm{~b}$ & $96,00 \mathrm{a}$ & $0,42 \mathrm{a}$ & $0,09 \mathrm{~b}$ & $50,36 \mathrm{~d}$ & $1,16 \mathrm{~d}$ & $75,50 \mathrm{~b}$ & $30,50 \mathrm{a}$ & $20,25 \mathrm{a}$ \\
\hline HELIO 250 & $45,25 \mathrm{a}$ & $87,00 \mathrm{a}$ & $0,48 \mathrm{a}$ & $0,08 \mathrm{~b}$ & $104,49 \mathrm{~b}$ & $2,76 \mathrm{a}$ & $81,00 \mathrm{~b}$ & $20,75 b$ & $15,89 \mathrm{~b}$ \\
\hline SYN $3950 \mathrm{HO}$ & $43,25 b$ & $90,00 \mathrm{a}$ & $0,36 \mathrm{~b}$ & $0,10 \mathrm{~b}$ & $53,79 \mathrm{~d}$ & $1,26 \mathrm{~d}$ & $79,00 \mathrm{~b}$ & $23,25 b$ & $16,52 \mathrm{~b}$ \\
\hline BRS 323 & $48,50 \mathrm{a}$ & $96,00 \mathrm{a}$ & $0,46 \mathrm{a}$ & $0,08 \mathrm{~b}$ & $77,97 \mathrm{c}$ & $1,76 \mathrm{c}$ & $93,00 \mathrm{a}$ & $33,00 \mathrm{a}$ & $26,09 \mathrm{a}$ \\
\hline MG 360 & $46,75 \mathrm{a}$ & $95,50 \mathrm{a}$ & $0,40 \mathrm{a}$ & $0,09 \mathrm{~b}$ & $69,07 \mathrm{c}$ & $1,62 \mathrm{c}$ & $78,50 \mathrm{~b}$ & $32,50 \mathrm{a}$ & $22,08 \mathrm{a}$ \\
\hline GNZ NEON & $36,25 \mathrm{c}$ & $94,00 \mathrm{a}$ & $0,37 \mathrm{~b}$ & $0,09 \mathrm{~b}$ & $39,30 \mathrm{~d}$ & $0,85 \mathrm{~d}$ & $81,00 \mathrm{~b}$ & $17,25 \mathrm{~b}$ & $12,02 \mathrm{~b}$ \\
\hline HLA 2012 & $47,75 \mathrm{a}$ & $89,50 \mathrm{a}$ & $0,43 \mathrm{a}$ & $0,12 \mathrm{a}$ & 136,93 a & $3,04 \mathrm{a}$ & $79,00 \mathrm{~b}$ & $30,75 \mathrm{a}$ & $21,52 \mathrm{a}$ \\
\hline MG 305 & $49,50 \mathrm{a}$ & $89,50 \mathrm{a}$ & $0,37 \mathrm{~b}$ & $0,08 \mathrm{~b}$ & $125,65 \mathrm{a}$ & $2,93 \mathrm{a}$ & $78,50 \mathrm{~b}$ & $18,25 \mathrm{~b}$ & $13,93 \mathrm{~b}$ \\
\hline HELIO 251 & $45,25 \mathrm{a}$ & $97,00 \mathrm{a}$ & $0,39 \mathrm{~b}$ & $0,07 \mathrm{~b}$ & $79,34 \mathrm{c}$ & $1,79 \mathrm{c}$ & $84,00 \mathrm{~b}$ & $21,25 \mathrm{~b}$ & $15,61 \mathrm{~b}$ \\
\hline AGUARÁ 06 & $42,75 \mathrm{~b}$ & $77,00 \mathrm{a}$ & $0,37 \mathrm{~b}$ & $0,09 \mathrm{~b}$ & $54,94 \mathrm{~d}$ & $1,28 \mathrm{~d}$ & $79,50 \mathrm{~b}$ & $18,00 \mathrm{~b}$ & $14,14 \mathrm{~b}$ \\
\hline AGUARÁ 04 & $47,50 \mathrm{a}$ & $91,00 \mathrm{a}$ & $0,42 \mathrm{a}$ & $0,08 \mathrm{~b}$ & $121,85 \mathrm{a}$ & $2,78 \mathrm{a}$ & $84,50 \mathrm{~b}$ & $27,75 \mathrm{a}$ & $20,78 \mathrm{a}$ \\
\hline PARAISO 20 & $48,00 \mathrm{a}$ & $89,00 \mathrm{a}$ & $0,37 \mathrm{~b}$ & $0,09 \mathrm{~b}$ & $99,13 \mathrm{~b}$ & $2,23 \mathrm{~b}$ & $77,50 \mathrm{~b}$ & $17,50 \mathrm{~b}$ & $14,25 \mathrm{~b}$ \\
\hline SYN 045 & $43,25 b$ & $92,00 \mathrm{a}$ & $0,43 \mathrm{a}$ & $0,09 \mathrm{~b}$ & $50,37 \mathrm{~d}$ & $1,14 \mathrm{~d}$ & $79,00 \mathrm{~b}$ & $23,25 b$ & $14,67 \mathrm{~b}$ \\
\hline Mínimo & 36,25 & 77,00 & 0,36 & 0,07 & 39,30 & 0,85 & 74,50 & 17,25 & 12,02 \\
\hline Média & 45,50 & 91,28 & 0,41 & 0,09 & 83,70 & 2,95 & 80,94 & 24,02 & 17,61 \\
\hline Máximo & 49,50 & 97,00 & 0,48 & 0,12 & 136,93 & 3,04 & 93,00 & 33,00 & 26,09 \\
\hline Desvio Padrão & 3,25 & 4,89 & 0,04 & 0,01 & 31,72 & 0,73 & 5,11 & 5,46 & 3,75 \\
\hline Variância & 10,58 & 23,90 & 0,00 & 0,00 & 1005,85 & 0,54 & 26,06 & 29,82 & 14,09 \\
\hline QM & 42,33 & 95,60 & 0,01 & 0,00 & 4023,41 & 2,16 & 104,25 & 119,28 & 56,37 \\
\hline Teste F & 9,19 & 3,37 & 4,98 & 6,63 & 21,49 & 22,34 & 12,64 & 3,56 & 3,86 \\
\hline$h_{a}^{2}$ & 89,12 & 70,34 & 79,91 & 84,91 & 95,35 & 95,52 & 92,09 & 71,92 & 74,10 \\
\hline $\mathrm{CV}(\%)$ & 4,72 & 5,83 & 7,89 & 9,73 & 16,35 & 15,95 & 3,55 & 24,10 & 21,70 \\
\hline
\end{tabular}

Letras maiúsculas comparam o mesmo genótipo nos diferentes ambientes. Letras minúsculas comparam os genótipos dentro do mesmo ambiente. Letras iguais indicam que não há diferença estatística entre os resultados, enquanto letras diferentes indicam diferença estatística (Teste Scott-Knott a 1\%). 
Tabela 2. Valores médios para o teste de padrão de germinação (TPG) em areia, teste padrão de germinação (TPG) em papel, peso de matéria verde e de matéria seca (PMV e PMS), condutividade elétrica (CE), lixiviados de potássio (LIX), envelhecimento acelerado (EA), emergência de plântulas em campo (EC) e, índice de velocidade de emergência (IVE) em campo, submetidos ao teste de Scott-Knott a 1\%. Embrapa Produtos e Mercado, Recanto das Emas, DF, 2014 (Fazenda Sucupira).

\begin{tabular}{|c|c|c|c|c|c|c|c|c|c|}
\hline Genótipo & TPG areia & TPG papel & PMV & PMS & $\mathbf{C E}$ & LIX & EA & EC & IVE \\
\hline CF 101 & $44,50 \mathrm{a}$ & $88,00 \mathrm{a}$ & $0,48 \mathrm{~b}$ & $0,11 \mathrm{~b}$ & $68,47 \mathrm{~b}$ & $1,51 \mathrm{a}$ & $71,50 \mathrm{~b}$ & $34,00 \mathrm{a}$ & $24,45 \mathrm{a}$ \\
\hline ADV 5504 & $40,75 \mathrm{a}$ & $82,50 \mathrm{a}$ & $0,49 \mathrm{~b}$ & $0,10 \mathrm{c}$ & $76,08 \mathrm{~b}$ & $1,65 \mathrm{a}$ & $74,50 \mathrm{~b}$ & $32,75 \mathrm{a}$ & $22,65 \mathrm{~b}$ \\
\hline BRS G42 & $43,75 \mathrm{a}$ & $94,00 \mathrm{a}$ & $0,49 \mathrm{~b}$ & $0,10 \mathrm{c}$ & $63,22 \mathrm{~b}$ & $1,31 \mathrm{~b}$ & $71,50 \mathrm{~b}$ & $35,75 \mathrm{a}$ & $23,38 \mathrm{~b}$ \\
\hline M734 (T) & $39,00 \mathrm{a}$ & $95,50 \mathrm{a}$ & $0,49 \mathrm{~b}$ & $0,09 \mathrm{c}$ & $42,41 \mathrm{c}$ & $0,96 \mathrm{~b}$ & $83,50 \mathrm{a}$ & $39,50 \mathrm{a}$ & $25,23 \mathrm{a}$ \\
\hline HELIO 250 & $45,00 \mathrm{a}$ & $83,00 \mathrm{a}$ & $0,54 \mathrm{a}$ & $0,15 \mathrm{a}$ & $98,25 \mathrm{a}$ & $2,08 \mathrm{a}$ & $69,00 \mathrm{c}$ & $30,75 \mathrm{a}$ & $22,93 \mathrm{~b}$ \\
\hline SYN $3950 \mathrm{HO}$ & $42,50 \mathrm{a}$ & $87,00 \mathrm{a}$ & $0,48 \mathrm{~b}$ & $0,09 \mathrm{c}$ & $61,60 \mathrm{~b}$ & $1,47 \mathrm{a}$ & $67,00 \mathrm{c}$ & $28,00 \mathrm{a}$ & $20,57 \mathrm{~b}$ \\
\hline BRS 323 & $42,00 \mathrm{a}$ & $88,00 \mathrm{a}$ & $0,49 \mathrm{~b}$ & $0,12 \mathrm{~b}$ & $62,93 \mathrm{~b}$ & $1,54 \mathrm{a}$ & $70,50 \mathrm{~b}$ & $33,50 \mathrm{a}$ & $25,23 \mathrm{a}$ \\
\hline MG 360 & $40,25 \mathrm{a}$ & $90,00 \mathrm{a}$ & $0,52 \mathrm{~b}$ & $0,12 b$ & $49,46 \mathrm{c}$ & $1,06 \mathrm{~b}$ & $84,50 \mathrm{a}$ & $31,25 \mathrm{a}$ & $21,66 \mathrm{~b}$ \\
\hline GNZ NEON & $41,00 \mathrm{a}$ & $96,00 \mathrm{a}$ & $0,56 \mathrm{a}$ & $0,12 \mathrm{~b}$ & $31,80 \mathrm{c}$ & $0,71 \mathrm{~b}$ & $65,50 \mathrm{c}$ & $28,00 \mathrm{a}$ & $19,63 \mathrm{~b}$ \\
\hline HLA 2012 & $44,75 \mathrm{a}$ & $87,50 \mathrm{a}$ & $0,50 \mathrm{~b}$ & $0,11 \mathrm{~b}$ & $85,52 \mathrm{a}$ & $1,74 \mathrm{a}$ & $75,00 \mathrm{~b}$ & $39,50 \mathrm{a}$ & $28,05 \mathrm{a}$ \\
\hline MG 305 & $43,50 \mathrm{a}$ & $74,00 \mathrm{a}$ & $0,58 \mathrm{a}$ & $0,12 \mathrm{~b}$ & $71,84 \mathrm{~b}$ & $1,56 \mathrm{a}$ & $67,00 \mathrm{c}$ & $31,75 \mathrm{a}$ & $23,36 \mathrm{~b}$ \\
\hline HELIO 251 & $41,00 \mathrm{a}$ & $91,00 \mathrm{a}$ & $0,58 \mathrm{a}$ & $0,10 \mathrm{c}$ & $49,76 \mathrm{c}$ & $1,16 \mathrm{~b}$ & $87,50 \mathrm{a}$ & $44,50 \mathrm{a}$ & $30,69 \mathrm{a}$ \\
\hline AGUARÁ 06 & $41,25 \mathrm{a}$ & $89,50 \mathrm{a}$ & $0,49 \mathrm{~b}$ & $0,12 \mathrm{~b}$ & $70,93 \mathrm{~b}$ & $1,88 \mathrm{a}$ & $66,00 \mathrm{c}$ & $36,25 \mathrm{a}$ & $27,26 \mathrm{a}$ \\
\hline AGUARÁ 04 & $41,25 \mathrm{a}$ & $83,50 \mathrm{a}$ & $0,55 \mathrm{a}$ & $0,12 \mathrm{~b}$ & $72,58 \mathrm{~b}$ & $1,62 \mathrm{a}$ & $75,00 \mathrm{~b}$ & $36,00 \mathrm{a}$ & $26,50 \mathrm{a}$ \\
\hline PARAISO 20 & $46,50 \mathrm{a}$ & $94,50 \mathrm{a}$ & $0,52 \mathrm{~b}$ & $0,15 \mathrm{a}$ & $72,16 b$ & $2,11 \mathrm{a}$ & $73,50 \mathrm{~b}$ & $34,25 \mathrm{a}$ & $26,03 \mathrm{a}$ \\
\hline SYN 045 & $43,25 \mathrm{a}$ & $91,00 \mathrm{a}$ & $0,58 \mathrm{a}$ & $0,11 b$ & $45,34 \mathrm{c}$ & $0,83 \mathrm{~b}$ & $80,00 \mathrm{a}$ & $28,25 \mathrm{a}$ & $20,97 \mathrm{~b}$ \\
\hline Mínimo & 39,00 & 74 & 0,48 & 0,09 & 31,80 & 0,71 & 65,50 & 28,00 & 19,63 \\
\hline Média & 42,52 & 88,44 & 0,52 & 0,11 & 63,89 & 1,45 & 73,84 & 34,00 & 24,29 \\
\hline Máximo & 46,50 & 96 & 0,58 & 0,15 & 98,25 & 2,11 & 87,50 & 44,50 & 30,69 \\
\hline Desvio Padrão & 2,04 & 5,73 & 0,04 & 0,02 & 16,98 & 0,42 & 6,85 & 4,57 & 2,98 \\
\hline Variância & 4,18 & 32,83 & 0,00 & 0,00 & 288,30 & 0,18 & 46,99 & 20,87 & 8,89 \\
\hline QM & 16,72 & 131,32 & 0,01 & 0,00 & 1153,18 & 0,70 & 187,96 & 83,47 & 35,58 \\
\hline Teste F & 1,40 & 2,71 & 3,50 & 8,84 & 12,98 & 6,38 & 13,77 & 2,95 & 3,48 \\
\hline$h_{a}^{2}$ & 28,55 & 63,03 & 71,42 & 88,69 & 92,30 & 84,34 & 92,74 & 66,15 & 71,30 \\
\hline $\mathrm{CV}$ & 8,13 & 7,88 & 7,79 & 10,16 & 14,75 & 22,86 & 5,00 & 15,63 & 13,16 \\
\hline
\end{tabular}

Letras maiúsculas comparam o mesmo genótipo nos diferentes ambientes. Letras minúsculas comparam os genótipos dentro do mesmo ambiente. Letras iguais indicam que não há diferença estatística entre os resultados, enquanto letras diferentes indicam diferença estatística (Teste Scott-Knott a 1\%). 
Tabela 3. Valores médios para o teste de padrão de germinação (TPG) em areia, teste padrão de germinação (TPG) em papel, peso de matéria verde e de matéria seca (PMV e PMS), condutividade elétrica (CE), lixiviados de potássio (LIX), envelhecimento acelerado (EA), emergência de plântulas em campo (EC) e, índice de velocidade de emergência (IVE) em campo, submetidos ao teste de Scott-Knott a 1\%. Embrapa Cerrados, Planaltina, DF, 2014 (CPAC 02).

\begin{tabular}{|c|c|c|c|c|c|c|c|c|c|}
\hline Genótipo & TPG areia & TPG papel & PMV & PMS & $\mathbf{C E}$ & LIX & EA & EC & IVE \\
\hline CF 101 & $45,25 \mathrm{a}$ & $86,50 \mathrm{a}$ & $0,42 \mathrm{~b}$ & $0,10 \mathrm{~b}$ & 90,85 a & $2,10 \mathrm{a}$ & $82,50 \mathrm{a}$ & $35,50 \mathrm{a}$ & $25,20 \mathrm{a}$ \\
\hline ADV 5504 & $43,00 \mathrm{~b}$ & $77,50 \mathrm{a}$ & $0,39 \mathrm{~b}$ & $0,10 \mathrm{~b}$ & $75,03 \mathrm{~b}$ & $1,53 \mathrm{~b}$ & $85,00 \mathrm{a}$ & $16,00 \mathrm{~b}$ & $13,11 \mathrm{~b}$ \\
\hline BRS G42 & $43,25 \mathrm{~b}$ & $83,00 \mathrm{a}$ & $0,45 \mathrm{a}$ & $0,14 \mathrm{a}$ & $61,91 \mathrm{~b}$ & $1,30 \mathrm{~b}$ & $78,00 \mathrm{a}$ & $34,25 \mathrm{a}$ & $22,92 \mathrm{a}$ \\
\hline M734 (T) & $47,75 \mathrm{a}$ & $98,50 \mathrm{a}$ & $0,46 \mathrm{a}$ & $0,09 \mathrm{~b}$ & $36,24 \mathrm{c}$ & $0,87 \mathrm{~d}$ & $80,00 \mathrm{a}$ & $35,75 \mathrm{a}$ & $22,67 \mathrm{a}$ \\
\hline HELIO 250 & $46,50 \mathrm{a}$ & $83,50 \mathrm{a}$ & $0,43 \mathrm{~b}$ & $0,11 \mathrm{~b}$ & $92,42 \mathrm{a}$ & $2,15 \mathrm{a}$ & $73,50 \mathrm{~b}$ & $35,75 \mathrm{a}$ & $23,56 \mathrm{a}$ \\
\hline SYN 3950HO & $42,00 \mathrm{~b}$ & $81,50 \mathrm{a}$ & $0,41 \mathrm{~b}$ & $0,09 \mathrm{~b}$ & $45,67 \mathrm{c}$ & $0,10 \mathrm{c}$ & $70,50 \mathrm{~b}$ & $15,75 \mathrm{~b}$ & $11,88 \mathrm{~b}$ \\
\hline BRS 323 & $49,25 \mathrm{a}$ & $87,50 \mathrm{a}$ & $0,49 \mathrm{a}$ & $0,10 \mathrm{~b}$ & $66,91 \mathrm{~b}$ & $1,54 \mathrm{~b}$ & $87,00 \mathrm{a}$ & $24,50 \mathrm{~b}$ & $19,08 \mathrm{a}$ \\
\hline MG 360 & $37,75 \mathrm{~b}$ & $85,50 \mathrm{a}$ & $0,47 \mathrm{a}$ & $0,12 \mathrm{a}$ & $48,63 \mathrm{c}$ & $1,25 \mathrm{c}$ & $81,00 \mathrm{a}$ & $14,75 \mathrm{~b}$ & $10,64 \mathrm{~b}$ \\
\hline GNZ NEON & $38,75 \mathrm{~b}$ & $84,00 \mathrm{a}$ & $0,45 \mathrm{a}$ & $0,11 \mathrm{~b}$ & $38,37 \mathrm{c}$ & $0,80 \mathrm{~d}$ & $72,00 \mathrm{~b}$ & $27,75 \mathrm{a}$ & $18,60 \mathrm{a}$ \\
\hline HLA 2012 & $45,00 \mathrm{a}$ & $87,50 \mathrm{a}$ & $0,47 \mathrm{a}$ & $0,11 \mathrm{~b}$ & $70,21 \mathrm{~b}$ & $1,60 \mathrm{~b}$ & $84,00 \mathrm{a}$ & $32,75 \mathrm{a}$ & $21,37 \mathrm{a}$ \\
\hline MG 305 & $43,25 \mathrm{~b}$ & $85,50 \mathrm{a}$ & $0,49 \mathrm{a}$ & $0,10 \mathrm{~b}$ & $69,67 \mathrm{~b}$ & $1,52 \mathrm{~b}$ & $70,50 \mathrm{~b}$ & $17,00 \mathrm{~b}$ & $13,04 \mathrm{~b}$ \\
\hline HELIO 251 & $40,25 \mathrm{~b}$ & $90,00 \mathrm{a}$ & $0,44 \mathrm{~b}$ & $0,10 \mathrm{~b}$ & $40,55 \mathrm{c}$ & $0,10 \mathrm{c}$ & $68,50 \mathrm{~b}$ & $11,75 \mathrm{~b}$ & $10,17 \mathrm{~b}$ \\
\hline AGUARÁ 06 & $39,25 \mathrm{~b}$ & $85,00 \mathrm{a}$ & $0,41 \mathrm{~b}$ & $0,12 \mathrm{a}$ & $31,68 \mathrm{c}$ & $0,63 \mathrm{~d}$ & $82,00 \mathrm{a}$ & $23,00 \mathrm{~b}$ & $16,29 b$ \\
\hline AGUARÁ 04 & $45,50 \mathrm{a}$ & 86,00 a & $0,50 \mathrm{a}$ & $0,12 \mathrm{a}$ & $62,31 \mathrm{~b}$ & $1,45 \mathrm{~b}$ & $70,00 \mathrm{~b}$ & 33,00 a & 24,36 a \\
\hline PARAISO 20 & $48,50 \mathrm{a}$ & $85,50 \mathrm{a}$ & $0,40 \mathrm{~b}$ & $0,12 \mathrm{a}$ & $72,03 \mathrm{~b}$ & $1,56 \mathrm{~b}$ & $58,00 \mathrm{c}$ & $11,00 \mathrm{~b}$ & $9,41 \mathrm{~b}$ \\
\hline SYN 045 & $40,5 \mathrm{~b}$ & $86,00 \mathrm{a}$ & $0,47 \mathrm{a}$ & $0,09 \mathrm{~b}$ & $36,43 \mathrm{c}$ & $0,77 \mathrm{~d}$ & $80,50 \mathrm{a}$ & $17,25 \mathrm{~b}$ & $13,14 \mathrm{~b}$ \\
\hline Mínimo & 37,75 & 77,50 & 0,39 & 0,09 & 31,68 & 0,63 & 58,00 & 11,00 & 9,41 \\
\hline Média & 43,48 & 85,81 & 0,45 & 0,11 & 58,68 & 1,32 & 76,44 & 24,11 & 17,21 \\
\hline Máximo & 49,25 & 98,50 & 0,50 & 0,14 & 92,42 & 2,15 & 87,00 & 35,75 & 25,20 \\
\hline Desvio Padrão & 3,56 & 4,40 & 0,03 & 0,01 & 19,50 & 0,45 & 7,77 & 9,37 & 5,62 \\
\hline Variância & 12,69 & 19,33 & 0,00 & 0,00 & 380,22 & 0,20 & 60,36 & 87,82 & 31,61 \\
\hline QM & 50,75 & 77,32 & 0,00 & 0,00 & 1520,87 & 0,81 & 241,45 & 351,30 & 126,43 \\
\hline Teste F & 4,79 & 2,57 & 2,96 & 4,15 & 27,04 & 24,50 & 7,36 & 9,29 & 10,84 \\
\hline$h_{a}^{2}$ & 79,11 & 61,04 & 66,24 & 75,89 & 96,30 & 95,92 & 86,42 & 89,24 & 90,78 \\
\hline $\mathrm{CV}$ & 7,49 & 6,40 & 8,92 & 12,61 & 12,78 & 13,83 & 7,49 & 25,50 & 19,84 \\
\hline
\end{tabular}

Letras maiúsculas comparam o mesmo genótipo nos diferentes ambientes. Letras minúsculas comparam os genótipos dentro do mesmo ambiente. Letras iguais indicam que não há diferença estatística entre os resultados, enquanto letras diferentes indicam diferença estatística (Teste Scott-Knott a 1\%). 
Tabela 4. Estimativas dos coeficientes de correlação genotípica, fenotípica e ambiental entre os caracteres teste de padrão de germinação (TPG) em areia, teste padrão de germinação (TPG) em papel, peso de matéria verde e de matéria seca (PMV e PMS), condutividade elétrica (CE), lixiviados de potássio (LIX), envelhecimento acelerado (EA), emergência de plântulas em campo (EC) e, índice de velocidade de emergência (IVE) em campo, em 16 genótipos de girassol. Embrapa Cerrados, Planaltina, DF, 2014 (CPAC 01).

\begin{tabular}{|c|c|c|c|c|c|c|c|c|c|}
\hline \multirow{2}{*}{ Caracteres } & \multirow{2}{*}{ Correlações } & \multicolumn{8}{|c|}{ Caracteres } \\
\hline & & TPG papel & PMV & PMS & $\overline{C E}$ & LIX & $\overline{E A}$ & $\mathrm{EC}$ & IVE \\
\hline \multirow{3}{*}{$\begin{array}{l}\text { TPG } \\
\text { areia }\end{array}$} & $r_{g}$ & 0,0429 & 0,2571 & $-0,1413$ & 0,8229 & 0,813 & 0,1024 & 0,3632 & 0,5756 \\
\hline & $\mathrm{r}_{\mathrm{f}}$ & 0,0671 & 0,2323 & $-0,0945$ & 0,7592 & 0,7576 & 0,0993 & 0,3157 & 0,4885 \\
\hline & $r_{a}$ & 0,1842 & 0,1038 & 0,222 & 0,0092 & 0,1071 & 0,071 & 0,1426 & 0,1233 \\
\hline TPG & $r_{g}$ & & 0,2276 & $-0,2186$ & $-0,0904$ & $-0,1108$ & 0,3199 & 0,7318 & 0,6329 \\
\hline \multirow[t]{2}{*}{ papel } & $r_{f}$ & & 0,1691 & $-0,2017$ & $-0,1028$ & $-0,1277$ & 0,2412 & 0,4737 & 0,4058 \\
\hline & $r_{a}$ & & $-0,0064$ & $-0,1549$ & $-0,2449$ & $-0,3196$ & $-0,1062$ & $-0,1622$ & $-0,1846$ \\
\hline \multirow{3}{*}{ PMV } & $r_{g}$ & & & $-0,0956$ & 0,2095 & 0,2803 & 0,4896 & 0,6946 & 0,7149 \\
\hline & $\mathrm{r}_{\mathrm{f}}$ & & & 0,006 & 0,1444 & 0,2184 & 0,4328 & 0,5389 & 0,5608 \\
\hline & $r_{a}$ & & & 0,4871 & $-0,3981$ & $-0,2787$ & 0,1019 & 0,0519 & 0,0465 \\
\hline \multirow{3}{*}{ PMS } & $r_{g}$ & & & & 0,1335 & 0,0769 & $-0,2641$ & 0,2999 & 0,151 \\
\hline & $r_{f}$ & & & & 0,1 & 0,0582 & $-0,2195$ & 0,2327 & 0,1213 \\
\hline & $r_{a}$ & & & & $-0,2405$ & $-0,1343$ & 0,1282 & $-0,0082$ & 0,0079 \\
\hline \multirow{3}{*}{$\mathrm{CE}$} & $r_{g}$ & & & & & 0,9928 & $-0,1505$ & 0,0232 & 0,2206 \\
\hline & $r_{f}$ & & & & & 0,9882 & $-0,139$ & 0,0209 & 0,1869 \\
\hline & $r_{a}$ & & & & & 0,8926 & 0,0327 & 0,0149 & 0,0135 \\
\hline \multirow{3}{*}{ LIX } & $r_{g}$ & & & & & & $-0,108$ & $-0,013$ & 0,1887 \\
\hline & $r_{f}$ & & & & & & $-0,1038$ & 0,0041 & 0,1728 \\
\hline & $r_{a}$ & & & & & & $-0,0428$ & 0,1325 & 0,1303 \\
\hline \multirow{3}{*}{ EA } & $r_{g}$ & & & & & & & 0,3981 & 0,5185 \\
\hline & $r_{f}$ & & & & & & & 0,3315 & 0,4328 \\
\hline & $r_{a}$ & & & & & & & 0,0508 & 0,0318 \\
\hline \multirow{3}{*}{$\mathrm{EC}$} & $r_{g}$ & & & & & & & & 0,941 \\
\hline & $\mathrm{r}_{\mathrm{f}}$ & & & & & & & & 0,942 \\
\hline & $r_{a}$ & & & & & & & & 0,9459 \\
\hline
\end{tabular}


Tabela 5. Estimativas dos coeficientes de correlação genotípica, fenotípica e ambiental entre os caracteres teste de padrão de germinação (TPG) em areia, teste padrão de germinação (TPG) em papel, peso de matéria verde e de matéria seca (PMV e PMS), condutividade elétrica (CE), lixiviados de potássio (LIX), envelhecimento acelerado (EA), emergência de plântulas em campo (EC) e, índice de velocidade de emergência (IVE) em campo, em 16 genótipos de girassol. Embrapa Produtos e Mercado, Recanto das Emas, DF, 2014 (Fazenda Sucupira).

\begin{tabular}{|c|c|c|c|c|c|c|c|c|c|}
\hline \multirow{2}{*}{ Caracteres } & \multirow{2}{*}{ Correlações } & \multicolumn{8}{|c|}{ Caracteres } \\
\hline & & TPG papel & PMV & PMS & $\overline{C E}$ & LIX & $\overline{E A}$ & $\mathrm{EC}$ & IVE \\
\hline \multirow{3}{*}{$\begin{array}{l}\text { TPG } \\
\text { areia }\end{array}$} & $r_{g}$ & $-0,2578$ & 0,1618 & 1,4301 & 1,0979 & 1,2349 & $-0,7111$ & $-0,6743$ & $-0,2876$ \\
\hline & $r_{f}$ & $-0,1472$ & 0,0154 & 0,5882 & 0,5887 & 0,5788 & $-0,3691$ & $-0,1557$ & 0,0407 \\
\hline & $r_{a}$ & $-0,0735$ & $-0,1276$ & $-0,4624$ & 0,1069 & $-0,0813$ & $-0,0139$ & 0,2793 & 0,3765 \\
\hline TPG & $r_{g}$ & & $-0,1847$ & $-0,2323$ & $-0,7763$ & $-0,5692$ & 0,4422 & 0,3288 & 0,0576 \\
\hline \multirow[t]{2}{*}{ papel } & $r_{f}$ & & $-0,1937$ & $-0,2107$ & $-0,6045$ & $-0,4373$ & 0,2985 & 0,1691 & 0,0188 \\
\hline & $r_{a}$ & & $-0,2148$ & $-0,1813$ & $-0,0736$ & $-0,0926$ & $-0,242$ & $-0,1224$ & $-0,0607$ \\
\hline \multirow{3}{*}{ PMV } & $r_{g}$ & & & 0,1712 & $-0,2886$ & $-0,4852$ & 0,297 & $-0,0935$ & $-0,0328$ \\
\hline & $\mathrm{r}_{\mathrm{f}}$ & & & 0,2206 & $-0,2168$ & $-0,299$ & 0,2283 & $-0,0815$ & $-0,0233$ \\
\hline & $r_{a}$ & & & 0,4692 & 0,1176 & 0,3663 & $-0,0929$ & $-0,0556$ & 0,0002 \\
\hline \multirow{3}{*}{ PMS } & $r_{g}$ & & & & 0,5557 & 0,7047 & $-0,3644$ & $-0,2565$ & 0,112 \\
\hline & $r_{f}$ & & & & 0,5327 & 0,6386 & $-0,3284$ & $-0,2359$ & 0,0476 \\
\hline & $r_{a}$ & & & & 0,3205 & 0,2189 & 0,0232 & $-0,2014$ & $-0,2302$ \\
\hline \multirow{3}{*}{$\mathrm{CE}$} & $r_{g}$ & & & & & 0,9562 & $-0,393$ & 0,1311 & 0,3324 \\
\hline & $r_{f}$ & & & & & 0,9093 & $-0,3589$ & 0,0815 & 0,2754 \\
\hline & $r_{a}$ & & & & & 0,5979 & 0,0622 & $-0,1297$ & 0,0381 \\
\hline \multirow{3}{*}{ LIX } & $r_{g}$ & & & & & & $-0,4499$ & 0,2011 & 0,4911 \\
\hline & $r_{f}$ & & & & & & $-0,4061$ & 0,1209 & 0,3731 \\
\hline & $r_{a}$ & & & & & & $-0,0775$ & $-0,1271$ & $-0,0366$ \\
\hline \multirow{3}{*}{ EA } & $r_{g}$ & & & & & & & 0,617 & 0,4046 \\
\hline & $r_{f}$ & & & & & & & 0,5147 & 0,3457 \\
\hline & $r_{a}$ & & & & & & & 0,2005 & 0,1154 \\
\hline \multirow{3}{*}{$\mathrm{EC}$} & $r_{g}$ & & & & & & & & 0,926 \\
\hline & $\mathrm{r}_{\mathrm{f}}$ & & & & & & & & 0,9187 \\
\hline & $\mathrm{r}_{\mathrm{a}}$ & & & & & & & & 0,9073 \\
\hline
\end{tabular}


Tabela 6. Estimativas dos coeficientes de correlação genotípica, fenotípica e ambiental entre os caracteres teste de padrão de germinação (TPG) em areia, teste padrão de germinação (TPG) em papel, peso de matéria verde e de matéria seca (PMV e PMS), condutividade elétrica (CE), lixiviados de potássio (LIX), envelhecimento acelerado (EA), emergência de plântulas em campo (EC) e, índice de velocidade de emergência (IVE) em campo, em 16 genótipos de girassol. Embrapa Cerrados, Planaltina, DF, 2014 (CPAC 02).

\begin{tabular}{|c|c|c|c|c|c|c|c|c|c|}
\hline \multirow{2}{*}{ Caracteres } & \multirow{2}{*}{ Correlações } & \multicolumn{8}{|c|}{ Caracteres } \\
\hline & & TPG papel & PMV & PMS & $\mathrm{CE}$ & LIX & $\overline{\mathrm{EA}}$ & EC & IVE \\
\hline \multirow{3}{*}{$\begin{array}{l}\text { TPG } \\
\text { areia }\end{array}$} & $r_{g}$ & 0,3512 & $-0,0142$ & $-0,1392$ & 0,6767 & 0,6781 & $-0,0731$ & 0,4112 & 0,4737 \\
\hline & $r_{f}$ & 0,2994 & 0,1034 & $-0,0876$ & 0,5791 & 0,5788 & $-0,0615$ & 0,3786 & 0,4272 \\
\hline & $r_{a}$ & 0,1941 & 0,4283 & 0,0901 & $-0,1316$ & $-0,1294$ & $-0,0061$ & 0,2209 & 0,1856 \\
\hline \multirow{3}{*}{$\begin{array}{l}\text { TPG } \\
\text { papel }\end{array}$} & $r_{g}$ & & 0,5794 & $-0,4348$ & $-0,3651$ & $-0,2178$ & 0,0735 & 0,318 & 0,269 \\
\hline & $r_{f}$ & & 0,4276 & $-0,2795$ & $-0,3276$ & $-0,223$ & 0,025 & 0,2766 & 0,2329 \\
\hline & $r_{a}$ & & 0,1633 & 0,0536 & $-0,3973$ & $-0,4466$ & $-0,1233$ & 0,2046 & 0,1723 \\
\hline \multirow{3}{*}{ PMV } & $r_{g}$ & & & $-0,3135$ & $-0,1592$ & $-0,0515$ & 0,1392 & 0,3374 & 0,3641 \\
\hline & $r_{f}$ & & & $-0,0451$ & $-0,1366$ & $-0,0616$ & 0,1448 & 0,2477 & 0,2643 \\
\hline & $r_{a}$ & & & 0,6208 & $-0,0839$ & $-0,1752$ & 0,1842 & $-0,0613$ & $-0,1017$ \\
\hline \multirow{3}{*}{ PMS } & $r_{g}$ & & & & 0,0655 & 0,0501 & $-0,3097$ & 0,1298 & 0,1274 \\
\hline & $r_{f}$ & & & & 0,0738 & 0,0446 & $-0,2288$ & 0,1219 & 0,1165 \\
\hline & $r_{a}$ & & & & 0,1883 & 0,0188 & 0,1216 & 0,0937 & 0,0718 \\
\hline \multirow{3}{*}{$\mathrm{CE}$} & $r_{g}$ & & & & & 0,9976 & 0,001 & 0,3325 & 0,3938 \\
\hline & $r_{f}$ & & & & & 0,9838 & 0,0111 & 0,2976 & 0,3587 \\
\hline & $r_{a}$ & & & & & 0,6434 & 0,143 & $-0,1687$ & $-0,1637$ \\
\hline \multirow{3}{*}{ LIX } & $r_{g}$ & & & & & & 0,0186 & 0,3746 & 0,4289 \\
\hline & $r_{f}$ & & & & & & 0,0185 & 0,3244 & 0,3825 \\
\hline & $r_{a}$ & & & & & & 0,0205 & $-0,334$ & $-0,29$ \\
\hline \multirow{3}{*}{ EA } & $r_{g}$ & & & & & & & 0,397 & 0,3949 \\
\hline & $r_{f}$ & & & & & & & 0,3422 & 0,3457 \\
\hline & $r_{a}$ & & & & & & & $-0,0533$ & $-0,0366$ \\
\hline \multirow{3}{*}{ EC } & $r_{g}$ & & & & & & & & 0,9881 \\
\hline & $r_{f}$ & & & & & & & & 0,9856 \\
\hline & $r_{a}$ & & & & & & & & 0,9663 \\
\hline
\end{tabular}




\subsection{REFERÊNCIAS BIBLIOGRÁFICAS}

ALBUQUERQUE, M.C. de F.E.; MORO, F.V.; FAGIOLI, M.; RIBEIRO, M.C. Testes de condutividade elétrica e de lixiviação de potássio na avaliação da qualidade fisiológica de sementes de girassol. Revista Brasileira de Sementes, v.23, p.1-8, 2001.

BRASIL. Regras para análise de sementes. Ministério da Agricultura, Pecuária e Abastecimento. Secretaria de Defesa Agropecuária. Brasília, DF: Mapa/ACS, 2009. 399p.

CASTRO, C.; FARIAS, J.R.B. Ecofisiologia do girassol. In: LEITE, R.M.V.B.; BRIGHENTI, A.M.; CASTRO, C. Girassol no Brasil. Londrina: Embrapa Soja, 2005. p.163-218.

CRUZ, C.D. Programa Genes: aplicativo computacional em genética e estatística. Versão Windows - 2007. Viçosa: UFV, 1997. 442p.

FAGIOLI, M. Relação entre a condutividade elétrica de sementes e a emergência de plântulas de milho em campo. 1997. 74 f. Dissertação (Mestrado em Produção e Tecnologia de Sementes) - Universidade Estadual Paulista-UNESP, Jaboticabal-SP, 1997.

HAMPTON, J.G. \& TEKRONY, B.M. Conductivity test. In: HAMPTON, J.G.; TEKRONY, B.M. (Eds.) Handbook of vigour methods. 3.ed. Zürich: ISTA, 1995. p.22.

KEMPTHORNE, O. An introduction to genetic statistics. New York: John Wiley \& Sons, 1966. 545p.

MARCOS-FILHO, J. Teste de envelhecimento acelerado. In: KRZYZANOWSKI, F.C.; VIEIRA, R.D.; FRANÇA-NETO, J.B. (Eds.). Vigor de sementes: conceitos e testes. Londrina: ABRATES, 1999. p.3.1-3.24.

NAKAGAWA, J. Testes de vigor baseados na avaliação das plântulas. In: VIEIRA, R.D.; CARVALHO, N.M. (Eds.) Testes de vigor em sementes. Jaboticabal: FUNEP, 1994. p.49-85.

NAKAGAWA, J. Testes de vigor baseados no desempenho das plântulas. In: KRZYZANOSKI, F.C.; VIEIRA, R.D.; FRANÇA NETO, J.B. (Eds.). Vigor de sementes: conceitos e testes. Londrina: ABRATES, 1999. 
SANTOS, J.; VENCOVSKY, R. Correlação fenotípica e genética entre alguns caracteres agronômicos do feijoeiro (Phaseolus vulgaris L.). Ciência e Prática, v.10, n.3. p.265-272, 1986.

SCOTT, A.J.; KNOTT, M. Accouter analysis methods for grouping means in the analysis of variants. Biometrics, 30: p. 507-512, 1974.

VIEIRA, R.D..; KRZYZANOWSKI, F.C. Teste de condutividade elétrica. In: KRZYZANOWSKI, F.C.; VIEIRA, R.D.; FRANÇA-NETO, J.B. (Eds.). Vigor de sementes: conceitos e testes. Londrina: ABRATES, 1999. p.4.1-26. 